\title{
TRIGO: AVALIAÇÃO DE LINHAGENS DIAPLÓIDES OBTIDAS VIA CULTURA DE ANTERAS
}

\author{
MARCUS VINICIUS SALOMON
}

Dissertação apresentada à Escola Superior de Agricultura "Luiz de Queiroz”, Universidade de São Paulo, para a obtenção do título de Mestre em Agronomia, Área de Concentração:

Fitotecnia.

PIRACICABA

Estado de São Paulo - Brasil

Dezembro - 2001 


\title{
TRIGO: AVALIAÇÃO DE LINHAGENS DIAPLÓIDES OBTIDAS VIA CULTURA DE ANTERAS
}

\author{
MARCUS VINICIUS SALOMON
}

Engenheiro Agrônomo

\section{Orientador: Dr. CARLOS EDUARDO DE OLIVEIRA CAMARGO}

Dissertação apresentada à Escola

Superior de Agricultura "Luiz de Queiroz", Universidade de São Paulo, para a obtenção do título de Mestre em Agronomia, Área de Concentração: Fitotecnia.

PIRACICABA

Estado de São Paulo - Brasil

Dezembro - 2001 
Dados Internacionais de Catalogação na Publicação (CIP)

DIVISÃO DE BIBLIOTECA E DOCUMENTAÇÃO - ESALQ/USP

\section{Salomon, Marcus Vinicius}

Trigo : avaliação de linhagens diaplóides obtidas via cultura de anteras / Marcus Vinicius Salomon. - - Piracicaba, 2001.

$91 \mathrm{p}$.

Dissertação (mestrado) - - Escola Superior de Agricultura Luiz de Queiroz, 2001.

Bibliografia.

1. Cultivo in vitro 2. Genótipos 3. Linhagens vegetais 4. Trigo I. Título

CDD 633.11

"Permitida a cópia total ou parcial deste documento, desde que citada a fonte - $\mathrm{O}$ autor" 
Dedico este trabalho a minha esposa, Julieta, e a minha filha, Letícia, pelo constante apoio. 


\section{AGRADECIMENTOS}

Ao Dr. CARLOS EDUARDO DE OLIVEIRA CAMARGO, que, nos anos de convivência, muito me ensinou, contribuindo para meu crescimento científico e intelectual.

Ao Prof. DURVAL DOURADO NETO, pela atenção e apoio durante o processo de definição de orientação.

À ESCOLA SUPERIOR DE AGRICULTURA “LUIZ DE QUEIROZ”, pela oportunidade de realização do curso de mestrado.

À FUNDAÇÃO DE AMPARO À PESQUISA DO ESTADO DE SÃO PAULO (FAPESP), pela concessão da bolsa de mestrado e pelo apoio financeiro para a realização desta pesquisa.

Ao INSTITUTO AGRONÔMICO (IAC), em Campinas (SP), por colocar à minha disposição a área experimental e o laboratório.

Ao Dr. ANTONIO WILSON PENTEADO FERREIRA FILHO, pela atenção dedicada, amizade, sugestões e auxílio na discussão dos resultados.

Aos chefes das Estações Experimentais de Agronomia ARMANDO PETINELLI JÚNIOR, JAIRO LOPES DE CASTRO e JOAQUIM ADELINO DE AZEVEDO FILHO, pela ajuda nos trabalhos de campo.

Ao Sr. SÉRGIO MELO, funcionário da Estação Experimental de Agronomia de Monte Alegre do Sul, pela colaboração nos trabalhos de campo.

Aos amigos e funcionários que, de alguma forma, contribuíram para a realização deste trabalho. 


\section{SUMÁRIO}

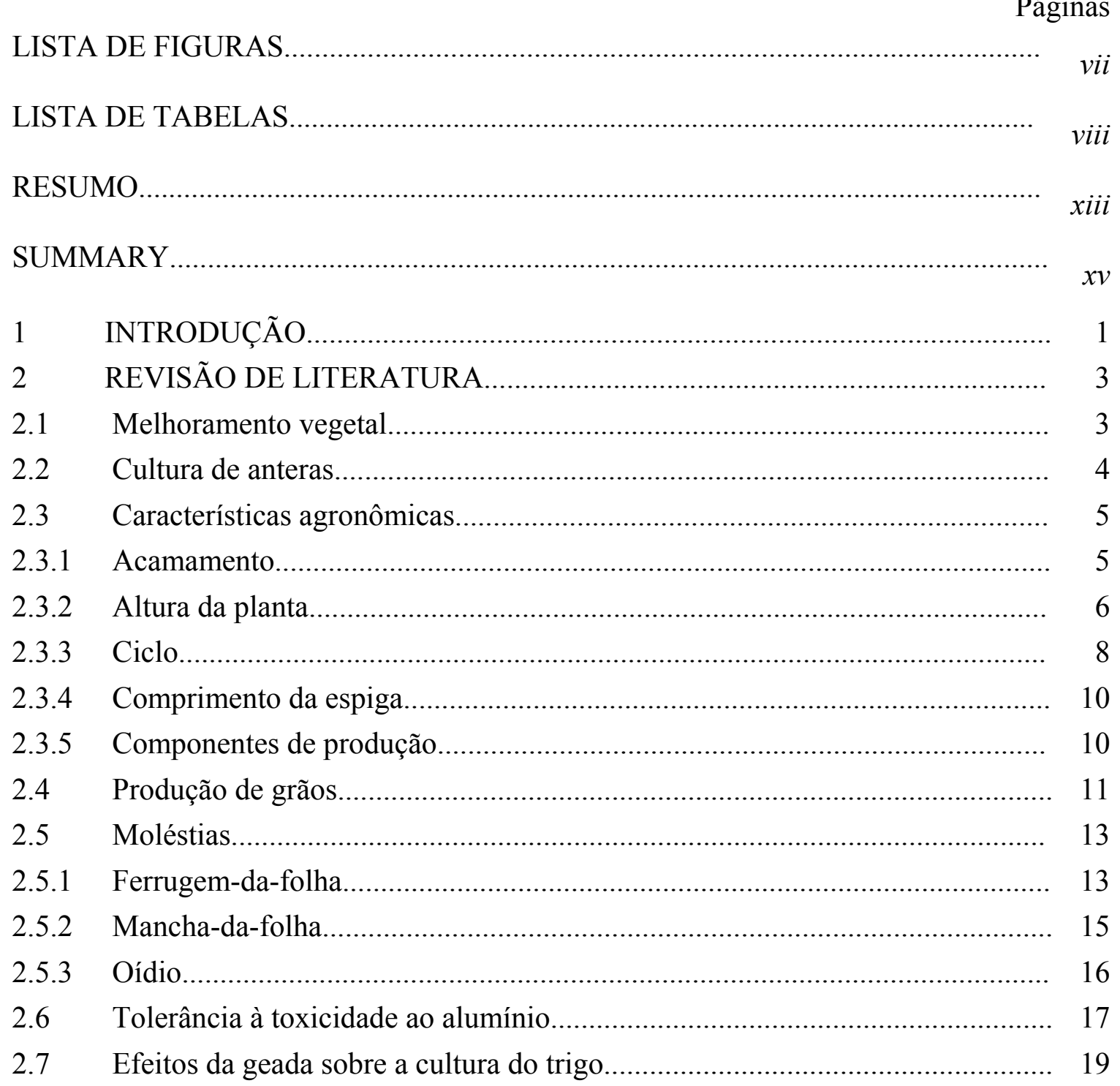


Páginas

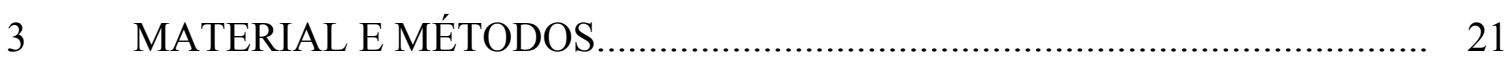

3.1 Origem das linhagens diaplóides de trigo................................................. 21

3.2 Avaliação das linhagens diaplóides de trigo................................................ 23

4 RESULTADOS E DISCUSSÃO............................................................. 31

4.1 Ensaio de Linhagens Diaplóides de Trigo I................................................ 31

4.2 Ensaio de Linhagens Diaplóides de Trigo II.............................................. 57

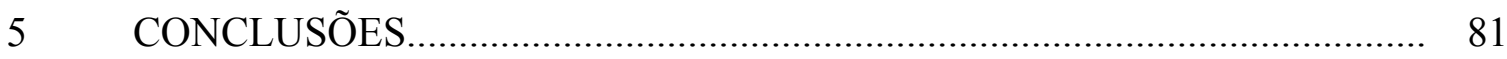

REFERÊNCIAS BIBLIOGRÁFICAS............................................................. 83 


\section{LISTA DE FIGURAS}

Página

1 Precipitações mensais ocorridas de abril a outubro na Estação Experimental de Agronomia de Capão Bonito, em 1999 e 2000 ........................................... 34

2 Temperaturas mínimas mensais ocorridas de abril a setembro na Estação Experimental de Agronomia de Tatuí, em 1999 e 2000.................................... 34

3 Temperaturas mínimas mensais ocorridas de maio a setembro na Estação Experimental de Monte Alegre do Sul, em 1999 e 2000..................................... 60 


\section{LISTA DE TABELAS}

Página

1 Genealogia dos genótipos avaliados no Ensaio de Linhagens Diaplóides de Trigo I, nas Estações Experimentais de Agronomia de Capão Bonito e Tatuí em 1999 e 2000.

2 Genealogia dos genótipos avaliados no Ensaio de Linhagens Diaplóides de Trigo II, nas Estações Experimentais de Agronomia de Monte Alegre do Sul e Tatuí em 1999 e 2000

3 Resultados das análises químicas das amostras de solo, na profundidade de 0-20 cm, dos locais onde foram instalados os Ensaios de Linhagens Diaplóides de Trigo I e II em 1999 e 2000.

4 Produção de grãos dos genótipos avaliados no Ensaio de Linhagens Diaplóides de Trigo I, nas Estações Experimentais de Agronomia de Capão Bonito e Tatuí em 1999 e 2000

5 Altura da planta dos genótipos avaliados no Ensaio de Linhagens Diaplóides de Trigo I, nas Estações Experimentais de Agronomia de Capão Bonito e Tatuí em 1999 e 2000. 
6 Ciclos da emergência ao florescimento e da emergência à maturação, em dias, dos genótipos avaliados no Ensaio de Linhagens Diaplóides de Trigo I, nas Estações Experimentais de Agronomia de Capão Bonito, em 1999 e 2000, e Tatuí em 2000

7 Porcentagem de acamamento dos genótipos avaliados no Ensaio de Linhagens Diaplóides de Trigo I, nas Estações Experimentais de Agronomia de Capão Bonito e Tatuí em 1999 e 2000

8 Porcentagem de área foliar infectada pelo agente causal da ferrugem-da-folha dos genótipos avaliados no Ensaio de Linhagens Diaplóides de Trigo I, nas Estações Experimentais de Agronomia de Capão Bonito e Tatuí em 1999 e 2000

9 Porcentagem de área foliar infectada pelo agente causal da mancha-da-folha dos genótipos avaliados no Ensaio de Linhagens Diaplóides de Trigo I, nas Estações Experimentais de Agronomia de Capão Bonito e Tatuí em 1999 e 2000

10 Porcentagem de área foliar infectada pelo agente causal do oídio dos genótipos avaliados no Ensaio de Linhagens Diaplóides de Trigo I, nas Estações Experimentais de Agronomia de Capão Bonito e Tatuí em 1999 e 2000

11 Comprimento médio da espiga dos genótipos avaliados no Ensaio de Linhagens Diaplóides de Trigo I, nas Estações Experimentais de Agronomia de Capão Bonito e Tatuí em 1999 e 2000

12 Número de espiguetas por espiga dos genótipos avaliados no Ensaio de Linhagens Diaplóides de Trigo I, nas Estações Experimentais de Agronomia de Capão Bonito e Tatuí em 1999 e 2000 
13 Número de grãos por espiga dos genótipos avaliados no Ensaio de Linhagens Diaplóides de Trigo I, nas Estações Experimentais de Agronomia de Capão Bonito e Tatuí em 1999 e 2000

14 Número de grãos por espigueta dos genótipos avaliados no Ensaio de Linhagens Diaplóides de Trigo I, nas Estações Experimentais de Agronomia de Capão Bonito e Tatuí em 1999 e 2000

15 Massa de cem grãos dos genótipos avaliados no Ensaio de Linhagens Diaplóides de Trigo I, nas Estações Experimentais de Agronomia de Capão Bonito e Tatuí em 1999 e 2000

16 Comprimento médio das raízes dos genótipos avaliados no Ensaio de Linhagens Diaplóides de Trigo I, após 72 horas de crescimento em solução normal, que se seguiu a um crescimento em solução tratamento contendo seis concentrações de alumínio (média de cinco repetições)

17 Produção de grãos dos genótipos avaliados no Ensaio de Linhagens Diaplóides de Trigo II, nas Estações Experimentais de Agronomia de Monte Alegre do Sul e Tatuí em 1999 e 2000

18 Altura da planta dos genótipos avaliados no Ensaio de Linhagens Diaplóides de Trigo II, nas Estações Experimentais de Agronomia de Monte Alegre do Sul e Tatuí em 1999 e 2000

19 Ciclos da emergência ao florescimento e da emergência à maturação, em dias, dos genótipos avaliados no Ensaio de Linhagens Diaplóides de Trigo II, nas Estações Experimentais de Agronomia de Monte Alegre do Sul, em 1999 e 2000, e Tatuí em 2000. 
20 Porcentagem de acamamento dos genótipos avaliados no Ensaio de Linhagens Diaplóides de Trigo II, nas Estações Experimentais de Agronomia de Monte Alegre do Sul e Tatuí em 1999 e 2000

21 Porcentagem de área foliar infectada pelo agente causal da ferrugem-da-folha dos genótipos avaliados no Ensaio de Linhagens Diaplóides de Trigo II, nas Estações Experimentais de Agronomia de Monte Alegre do Sul e Tatuí em 1999 e 2000

22 Porcentagem de área foliar infectada pelo agente causal da mancha-da-folha dos genótipos avaliados no Ensaio de Linhagens Diaplóides de Trigo II, nas Estações Experimentais de Agronomia de Monte Alegre do Sul e Tatuí em 1999 e 2000

23 Porcentagem de área foliar infectada pelo agente causal do oídio dos genótipos avaliados no Ensaio de Linhagens Diaplóides de Trigo II, nas Estações Experimentais de Agronomia de Monte Alegre do Sul e Tatuí em 1999 e 2000.

24 Comprimento médio da espiga dos genótipos avaliados no Ensaio de Linhagens Diaplóides de Trigo II, nas Estações Experimentais de Agronomia de Monte Alegre do Sul e Tatuí em 1999 e 2000.

25 Número de espiguetas por espiga dos genótipos avaliados no Ensaio de Linhagens Diaplóides de Trigo II, nas Estações Experimentais de Agronomia de Monte Alegre do Sul e Tatuí em 1999 e 2000

26 Número de grãos por espiga dos genótipos avaliados no Ensaio de Linhagens Diaplóides de Trigo II, nas Estações Experimentais de Agronomia de Monte Alegre do Sul e Tatuí em 1999 e 2000. 
27 Número de grãos por espigueta dos genótipos avaliados no Ensaio de Linhagens Diaplóides de Trigo II, nas Estações Experimentais de Agronomia de Monte Alegre do Sul e Tatuí em 1999 e 2000.............................................

28 Massa de cem grãos dos genótipos avaliados no Ensaio de Linhagens Diaplóides de Trigo II, nas Estações Experimentais de Agronomia de Monte

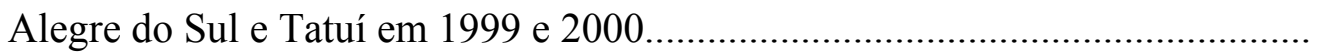

29 Comprimento médio das raízes dos genótipos avaliados no Ensaio de Linhagens Diaplóides de Trigo II, após 72 horas de crescimento em solução normal, que se seguiu a um crescimento em solução tratamento contendo seis concentrações de alumínio (média de cinco repetições)..................................... 


\title{
TRIGO: AVALIAÇÃO DE LINHAGENS DIAPLÓIDES OBTIDAS VIA CULTURA DE ANTERAS
}

\author{
Autor: MARCUS VINICIUS SALOMON \\ Orientador: Dr. CARLOS EDUARDO DE OLIVEIRA CAMARGO
}

\section{RESUMO}

Avaliaram-se 36 linhagens diaplóides de trigo, obtidas via cultura de anteras in vitro oriundas de plantas híbridas, em geração $\mathrm{F}_{1}$, divididas em dois ensaios com dezoito linhagens e dois cultivares controles (IAC-24 e IAC-289), nos anos de 1999 e 2000. Cada ensaio foi instalado em dois locais do Estado de São Paulo: Ensaio I - Estações Experimentais de Agronomia de Capão Bonito (solo ácido, sem aplicação de calcário e em condição de sequeiro) e Tatuí (solo ácido, com aplicação de calcário e em condição de irrigação por aspersão) e Ensaio II - Estações Experimentais de Agronomia de Tatuí e Monte Alegre do Sul (ambos em solo ácido com aplicação de calcário e condição de irrigação por aspersão). Em cada ensaio, avaliaram-se os seguintes parâmetros: acamamento, altura da planta, ciclos da emergência ao florescimento e da emergência à maturação, produção de grãos, resistência às moléstias, comprimento da espiga e componentes de produção. Todos os genótipos foram, também, avaliados quanto à tolerância à toxicidade de alumínio, em solução nutritiva, em condição de laboratório. No Ensaio I, destacaram-se, pela produção de grãos, as linhagens 4 (2.309 $\left.\mathrm{kg} \mathrm{ha}^{-1}\right)$ e 5 (2.319 $\mathrm{kg} \mathrm{ha}^{-1}$ ), provenientes do cruzamento PF70402/ALD"S"//PAT72160/ALD"S"/3/ PEW"S"/4/OPATA/5/IAC-60; 9 (2.150 $\left.\mathrm{kg} \mathrm{ha}^{-1}\right)$, provinda do cruzamento MLR"S"/ BUC"S"//BUC"S"/3/IAC-24, 11 (2.102 $\left.\mathrm{kg} \mathrm{ha}^{-1}\right)$ e 12 (2.056 $\left.\mathrm{kg} \mathrm{ha}^{-1}\right)$, oriundas do cruzamento TEPOCA/IAC-24. A 13 (JUN/GEN//IAC-24) apresentou as plantas mais baixas $(53 \mathrm{~cm})$. As linhagens 2, 4 e 18, originárias dos cruzamentos JUN/GEN//IAC-24, 
PF70402/ALD"S"//PAT72160/ALD"S"/3/PEW"S"/4/OPATA/5/IAC-60 e TEPOCA/ IAC-24, revelaram, ao mesmo tempo, moderada resistência aos agentes causais da ferrugem-da-folha e da mancha-da-folha. Todos os genótipos, com exceção do cultivar IAC-289 e da linhagem 13 (JUN/GEN//IAC-24), foram considerados tolerantes a $10 \mathrm{mg} \mathrm{L}^{-1}$ de $\mathrm{Al}^{3+}$, quando avaliados em solução nutritiva. No Ensaio II, a linhagem 8 (ANA/IAC-24) e o cultivar IAC-289 apresentaram elevadas produções de grão (3.311 e $3.341 \mathrm{~kg} \mathrm{ha}^{-1}$ respectivamente). A linhagem 13 exibiu o porte mais baixo $(61 \mathrm{~cm})$ entre os genótipos estudados e a 3 (ANA/IAC-24//IAC-24), mostruo, ao mesmo tempo, resistência ao agente causal da ferrugem-da-folha, moderada resistência ao agente da mancha-da-folha e imunidade ao agente causal do oídio. As linhagens 8 (ANA/IAC-24) e 14 (PF70402/ALD"S"/PAT72160/ ALD"S"/3/PEW"S"/4/OPATA/5/ IAC-60) mostraram elevada tolerância à toxicidade de alumínio, associada a alta produção de grãos. 


\title{
WHEAT: EVALUATION OF DIHAPLOID LINES ORIGINATED VIA ANTHER CULTURE.
}

\author{
Author: MARCUS VINICIUS SALOMON \\ Adviser: CARLOS EDUARDO DE OLIVEIRA CAMARGO
}

\section{SUMMARY}

Thirty six dihaploid wheat lines, originated via anther culture from $\mathrm{F}_{1}$ hybrid plants were evaluated in two trials with eighteen lines plus two control cultivars (IAC-24 and IAC-289), in 1999 and 2000. Each trial was carried out in two locations of the State of São Paulo: trial I - Capão Bonito Agronomy Experiment Station (acid soil without lime application and upland condition) and Tatuí Agronomy Experiment Station (acid soil with lime application and sprinkler irrigation condition) and trial II - Monte Alegre do Sul and Tatuí Agronomy Experiment Station (both with acid soil with lime application and sprinkler irrigation condition). In each the genotypes were evaluated for lodging, plant height, cycle from emergence to flowering and from emergence to maturation, grain yield, resistance to disease, head length and yield components. All genotypes were also evaluated for aluminum toxicity tolerance, in nutrient solution, under laboratory condition. Considering trail I, the lines $4\left(2.309 \mathrm{~kg} \mathrm{ha}^{-1}\right)$ and 5 (2.319 $\mathrm{kg} \mathrm{ha}^{-1}$ ) originated from the cross PF70402/ALD"S"//PAT72160/ALD"S"/3/PEW"S"/4/ OPATA/5/IAC-60, 9 (2.150 $\left.\mathrm{kg} \mathrm{ha}^{-1}\right)$ from the cross MLR"S"/BUC"S"//BUC"S"/3/ IAC-24, and the lines $11\left(2.102 \mathrm{~kg} \mathrm{ha}^{-1}\right)$ e $12\left(2.056 \mathrm{~kg} \mathrm{ha}^{-1}\right)$ from the cross TEPOCA/IAC-24, presented high grain yield. The line 13 (JUN/GEN//IAC-24) showed the shortest plants $(53 \mathrm{~cm})$. The lines 2,4 and 18 originated from crosses JUN/GEN//IAC-24, 
PF70402/ALD"S"//PAT72160/ALD"S"/3/PEW"S"/4/OPATA/5/IAC-60 and TEPOCA /IAC-24, showed at the same time moderate resistance to the causal agents of leaf rust and leaf spot. All genotypes, with exception of the cultivar IAC-289 and the line 13 (JUN/GEN//IAC-24), were considered tolerant to $10 \mathrm{mg} \mathrm{L}^{-1} \mathrm{Al}^{3+}$, when evaluated in nutrient solutions. Considering trial II, the line 8 (ANA/IAC-24) and the cultivar IAC-289 presented high grain yield (3.311 e $3.341 \mathrm{~kg} \mathrm{ha}^{-1}$ respectively). The line 3 (ANA/IAC-24//IAC-24) exhibited at the same time resistance to the causal agent of leaf rust, moderate resistance to the causal agent of leaf spot and immunity to the causal agent of powdery mildew. The lines 8 (ANA/IAC-24) and 14 (PF70402/ALD"S"// PAT72160/ALD“S”/3/PEW"S"/4/OPATA/5/IAC-60), also showed high tolerance to aluminum toxicity being associated to high grain yield, and so could be used in breeding programs with the objective to get cultivars for acid soils. 


\section{INTRODUÇÃO}

A história do trigo, no Brasil, está estreitamente relacionada com a própria história da Nação. A cultura do trigo foi introduzida, em 1556, na Capitania de São Vicente (SP). Daí, deslocou-se para os campos de Piratininga, onde se estabeleceu, dando origem aos primeiros moinhos. Por volta de 1737, imigrantes dos Açores introduziram-na no Rio Grande do Sul, com grande êxito. A partir de 1768, em virtude da grande produção de trigo e da fertilidade das terras, essa Província passou a ser denominada "o celeiro do Brasil", permitindo que, no período 1805-1810, o País apresentasse uma produção relativamente vultosa, que lhe possibilitou a exportação do cereal (Bayma, 1960).

O aparecimento da ferrugem, em 1811, reduziu as colheitas, desestimulou os produtores e provocou desvio para outras atividades, iniciando a decadência da cultura e obrigando o País a recorrer às importações para o abastecimento interno (Bayma, 1960; Tomasini, 1982).

A partir de 1967, o Brasil viveu um longo período com tendência geral de crescimento da produção, em vista das várias intervenções do Governo, incentivando a produção (Tomasini, 1982) e a pesquisa de trigo. Esta levou ao desenvolvimento de novos cultivares, mais bem adaptados às condições brasileiras, e preconizou a geração de novas técnicas de cultivo, as quais permitiram um aumento da produtividade (Ruedell, 1999).

Em conseqüência, principalmente, de fatores políticos, entre eles a privatização da comercialização do trigo nacional, a partir de 1990, houve um decréscimo da produção, ocasionado por uma redução na área de semeadura (Jacobsen, 1999). Em contrapartida, pelo crescimento da população e pela intensa migração para as grandes cidades, cresceu a busca por alimentos de preparo rápido e baixo custo, que têm 
o trigo como um dos principais componentes, proporcionando um aumento do seu consumo.

Atualmente, o Brasil necessita importar grande volume de trigo para atender a suas necessidades internas, ocupando um lugar de destaque como grande importador (Companhia Nacional de Abastecimento, 2001).

Em conseqüência do problema de abastecimento nacional, a conquista de novas regiões, até então não tritícolas, tem aumentado de modo significativo a produção nacional. Assim a obtenção de genótipos que melhor se adaptem às condições brasileiras de clima e solo é de grande importância, bem como o desenvolvimento de técnicas de produção que visem à redução dos custos e à busca de alternativas para minimizar a dependência externa.

Os programas de melhoramento genético de trigo, no País, buscam obter genótipos com ampla adaptabilidade e maior rendimento de grão. Entre eles, destaca-se o programa desenvolvido pelo Instituto Agronômico, Campinas (IAC), o qual procura desenvolver cultivares de porte semi-anão, com alto potencial produtivo e tolerantes à toxicidade de alumínio, mediante cruzamentos entre cultivares nacionais adaptados às condições de solo ácido e cultivares semi-anões com alto potencial produtivo de origem mexicana (Camargo et al., 1990, 1991b).

No processo convencional de melhoramento de plantas autógamas, após o cruzamento varietal, são necessárias de sete a nove gerações para se obter a estabilidade fenotípica e, conseqüentemente, alto grau de homozigose. Visando aumentar a eficiência na obtenção de cultivares de trigo, novas técnicas têm sido incorporadas aos programas de melhoramento genético, entre elas a obtenção de plantas diaplóides em gerações $F_{1}$ por meio da cultura de anteras in vitro, a qual diminui vários anos o processo de obtenção de novos cultivares, além de simplificar e tornar mais eficiente o processo de seleção (Camargo et al., 1999 e Moraes-Fernandes, 1987).

O presente trabalho objetivou avaliar genótipos diaplóides de trigo, obtidos em 1998, mediante a cultura de anteras in vitro, em comparação com os cultivares IAC-24 e IAC-289, resultantes do programa de melhoramento tradicional. 


\section{REVISÃO DE LITERATURA}

\subsection{Melhoramento vegetal}

Em um programa de melhoramento genético de plantas autógamas cujo objetivo principal é conseguir genótipos com alto rendimento e estabilidade de produção, o sucesso depende, principalmente, da escolha dos genitores com capacidade para produzir genótipos superiores, da adoção de um programa de melhoramento capaz de proporcionar recombinações genéticas de interesse e da capacidade do melhorista em selecionar os indivíduos superiores nas gerações segregantes (Allard, 1971).

Segundo Carvalho et al., citados por Gandin (1982), os caracteres de importância agronômica, cujo conhecimento da base genética é decisivo à implantação de um programa de melhoramento genético, em trigo, são os seguintes: arquitetura foliar, altura da planta, resistência à deiscência natural dos grãos, tolerância à acidez nociva do solo, período de floração e relação grãos/palha. A esses caracteres, pode-se acrescentar o próprio rendimento de grãos e seus componentes, já que a maioria dos programas de melhoramento genético objetiva a obtenção de genótipos com maior produtividade (Gandin, 1982).

O processo de evolução de qualquer espécie baseia-se na variabilidade genética, na seleção natural e/ou artificial, e no ajuste dos genótipos aos ambientes. Comprovada a variabilidade, a seleção assume o maior destaque no progresso genético.

Conforme Allard (1971), a escolha do método de melhoramento a adotar depende do sistema reprodutivo da espécie a ser trabalhada: para as autógamas, entre elas o trigo, os métodos mais eficientes podem ser agrupados nas seguintes categorias: a) seleção de plantas individuais com teste de progênies; b) seleção massal; c) hibridação, com as populações segregantes conduzidas por meio de métodos genealógico (pedigree), 
populacional (bulk) e retrocruzamento. Tais métodos se baseiam no fato de que a autofecundação ou retrocruzamento para um genitor conduz à homozigose.

O desenvolvimento de conhecimentos técnicos para a identificação de genótipos superiores na seleção artificial é uma das tarefas de maior importância para os programas de melhoramento vegetal. A participação direta dos efeitos ambientais sobre a manifestação genotípica de um indivíduo pode causar dificuldades aos melhoristas quanto à eficiência da seleção (Briggs \& Knowles, 1967). Tendo em vista esses aspectos, Camargo \& Ramos (1989) recomendaram iniciar na geração $F_{2}$ somente quando o caráter desejado for de fácil identificação e de alta herdabilidade. Para caracteres com ação gênica de difícil estimativa e reduzida herdabilidade, a intensificação da seleção deveria ser protelada para gerações mais avançadas (Allard, 1971), onde testes de progênies poderiam ser realizados (Camargo \& Ramos, 1989).

\subsection{Cultura de anteras}

Visando aumentar a eficiência na obtenção de cultivares de trigo, a técnica de cultura de anteras também tem sido utilizada no programa de melhoramento genético do Instituto Agronômico (IAC), para obtenção de plantas haplóides a partir das híbridas, em

geração $F_{1}$, uma vez que acelera, em vários anos, o processo de obtenção de novos cultivares, além de simplificar e tornar mais eficiente o processo de seleção (Camargo et al., 1999; Moraes-Fernandes, 1987 e Ramos et al., 2000).

Os haplóides são obtidos mediante a cultura de anteras, que consiste, basicamente, na coleta da inflorescência de trigo na fase de pré-antese, na extração das anteras assepticamente e na inoculação em meio de cultura apropriado (MoraesFernandes, 1987). O número de cromossomos das plantas haplóides regeneradas é restabelecido pelo emprego da colchicina (alcalóide de origem vegetal extraído de Colchicum autumnale L.), a qual afeta a divisão celular, inibindo a formação das fibras do fuso e impedindo a separação das cromátides irmãs durante a anáfase mitótica; conseqüentemente, o núcleo formado possuirá o dobro do número de cromossomos das células do tecido tratado. Dessa forma, a homozigose é obtida imediatamente, uma vez que cada cromossomo terá sua cópia exata, sendo também restaurada a fertilidade, pois a 
planta haplóide é estéril (Moraes-Fernandes, 1987). Partindo-se da geração $F_{1}$, obtêm-se plantas $100 \%$ homozigotas já na geração $F_{2}$.

A principal dificuldade da cultura de anteras está em identificar, para cada espécie, o meio de cultura mais apropriado para que ocorra a divisão celular, sobretudo para ativar e desativar os genes, no momento e no local apropriado, visando à diferenciação celular e, conseqüentemente, a obtenção de uma planta idêntica àquela de onde a célula ou conjunto de células foi retirado (Ramalho et al., 1995)

Camargo et al. (1999) citam a alta eficiência da técnica de cultura de anteras in vitro, na obtenção de cultivares de trigo com características agronômicas desejáveis.

\subsection{Características agronômicas}

\subsubsection{Acamamento}

O acamamento, característica de grande importância para a produção de trigo, influenciando-a diretamente, está relacionado a fatores genéticos e ambientais. Tal importância cresce quando o trigo é cultivado em condição de irrigação, a qual exige elevados rendimentos para cobrir os altos custos decorrentes do seu emprego.

Segundo Pires (1953), na obtenção de plantas resistentes, deve-se conjugar a altura, o diâmetro dos entrenós inferiores do colmo, sua elasticidade e a espessura de suas paredes.

Souza (1998), estudando cultivares de trigo no Rio Grande do Sul, em 1985-90, observou ampla variabilidade no material, sugerindo que a maior resistência ao acamamento poderia estar associada ao porte baixo e à boa condição de palha; exceções, porém, indicaram que outros fatores estariam associados à resistência ao acamamento.

Trabalho realizado por Laude \& Pauli (1956) mostrou que a ocorrência do acamamento uma a duas semanas antes do espigamento provocou um decréscimo de 30 a $35 \%$ na produção de grãos; durante o espigamento, de $27 \%$; nos dez dias posteriores ao espigamento, aumentou para $35 \%$ e, na frutificação (15-20 dias depois do espigamento), o decréscimo foi de $24 \%$. Para Weibel \& Pendleton (1964), os efeitos sobre a produção foram mais severos durante o espigamento, sendo as reduções nessa 
fase, no estádio de grão leitoso, na massa-macia e na massa-firme, de 31, 25, 20 e $12 \%$ respectivamente.

Segundo Laude \& Pauli (1956), os grandes decréscimos na produção, causados por acamamento, duas semanas depois do espigamento, podem ser devidos a restrições na translocação de substâncias, imposta pelo esmagamento dos tecidos e diminuição da água na planta. O menor teor de água nas folhas das plantas acamadas pode contribuir para o decréscimo da taxa fotossintética, da síntese de aminoácidos, da produção de carboidratos e de proteínas.

Além dos efeitos do acamamento sobre a produção, têm sido observados decréscimos sobre o peso do hectolitro e da massa do grão (Laude \& Pauli, 1956 e Weibel \& Pendleton, 1964), redução do número de grãos por espiga e do tamanho do grão (Laude \& Pauli, 1956).

A suscetibilidade ao acamamento tem sido associada à aplicação de fertilizantes nitrogenados, na qual, na maioria das vezes, verifica-se que as variedades altas tendem ao acamamento, enquanto as baixas são mais tolerantes, quando submetidas a altas doses de nitrogênio (Robins \& Domingo, 1962).

Linhagens originárias de cruzamentos entre trigo de primavera e de inverno, quando avaliadas em condição de campo com e sem irrigação, exibiram médias de acamamento entre 2 e $29 \%$, associando-se os maiores valores às plantas mais altas (Camargo et al., 1989).

Camargo et al. (1999), avaliando linhagens de trigo diaplóides, obtiveram acamamento variando de 0 a $40 \%$, onde os cultivares Al Res 104/84 e IAC-24, utilizados como controles, apresentaram média de 33\%.

\subsubsection{Altura da planta}

A baixa altura da planta é uma das características mais importantes no cultivo do trigo, principalmente, por estar associada, na maioria das vezes, a uma maior resistência ao acamamento, quando comparada às variedades de porte alto. Nesse sentido, realizaram-se inúmeros trabalhos de pesquisa nos países produtores do cereal, comprovando, o sucesso alcançado, a importância dessa peculiaridade. 
Observando as características do trigo, Vogel et al. (1956), Borojevic (1968) e Powell \& Schlehuber (1967) verificaram que a resistência ao acamamento era um dos fatores de maior influência no rendimento do produto final. Além disso, diversos trabalhos ressaltam outras vantagens dos trigos de porte baixo, tais como o alto potencial de rendimento devido à capacidade produtiva de perfilhos férteis e o grande número de espiguetas por espiga com alta fertilidade (Rawson \& Evans, 1971), maior tolerância aos danos causados por precipitações elevadas e pela ação dos ventos (Borojevic, 1968) e o aumento da relação grãos/palha (Powell \& Schlehuber, 1967).

A identificação de genes que condicionam o porte baixo foi o primeiro passo para o êxito na obtenção, seleção e lançamento de cultivares com essa característica. Segundo Vogel et al. (1956), o 'Norin 10' (CS 12699) foi o primeiro genótipo que reuniu a desejável combinação de altura baixa, resistência ao acamamento e às moléstias, e qualidade de grãos, no qual se fundamentou a maioria dos cruzamentos, visando à redução da altura das plantas de trigo.

Altos valores de herdabilidade para altura da planta de trigo foram calculados por Camargo \& Oliveira $(1981,1983)$ e Camargo \& Ramos (1989), mostrando a existência de efeitos aditivos na expressão genética desse caráter, e sugerindo que a seleção para altura seria efetiva nas primeiras gerações segregantes de um cruzamento.

Obtiveram-se correlações fenotípicas positivas e significativas para a produção de grãos e altura da planta, em cruzamentos envolvendo o cultivar IAC-5, de porte alto, e quatro diferentes fontes de nanismo (Camargo \& Oliveira, 1983).

Dados obtidos por Camargo \& Ramos (1989), nos quais os caracteres altura da planta e número de grãos por espigueta estão associados positivamente com a produção de grãos, mas não entre si, indicando que, para obter plantas de porte médio com maior número de grãos por espigueta e com alto potencial produtivo, deveriam ser selecionados para os dois primeiros caracteres nas primeiras gerações segregantes, pois ambos se mostraram independentes, e nas gerações $\mathrm{F}_{5}$ e $\mathrm{F}_{6}$ seriam efetuadas avaliações para a produção de grãos quando as progênies estivessem praticamente uniformes. Considerando a associação positiva entre plantas altas e produção de grãos, deveriam ser utilizadas grandes populações $F_{2}$ e $F_{3}$ para obter os recombinantes desejados de porte médio ou baixo. 
Quanto ao comprimento da espiga, em relação à altura total, Powell \& Schlehuber (1967) e Borojevic (1968) evidenciaram a possibilidade de selecionar plantas baixas com espigas grandes.

A altura da planta é um caráter com grande variabilidade (Camargo et al., 1999 e Scheeren et al., 1981). Segundo Camargo et al. (1999), plantas que medem até 90 cm são consideradas de porte baixo; de 91 a $120 \mathrm{~cm}$, de porte intermediário e, com mais de $121 \mathrm{~cm}$, de porte alto.

Os cultivares recomendados pela Comissão Técnica de Trigo, para 1999, são classificados como baixos: BR 18, IAC-24, IAC-287 e IAC-289 (<90 cm), e intermediários: IAC-120, IAC-350 e IAC-370 (91 a 120 cm) (IAC, 1999).

\subsubsection{Ciclo}

A capacidade dos melhoristas em ajustar o ciclo das variedades favorece o aumento da produção, uma vez que elas ficam expostas às condições ambientais adversas por menor período (Worland, 1998), além de permitir a escolha da época de semeadura mais adequada, a fim de aproveitar as condições ambientes mais favoráveis a seu desenvolvimento.

Resultados oriundos de estudos fisiológicos indicam que genótipos de trigo diferem expressivamente em suas respostas ao comprimento do dia e em relação às exigências de temperatura, do período de emergência ao início do espigamento (Federizzi et al., 1982).

Agronomicamente, os cultivares tritícolas são divididos em dois grupos distintos quanto às exigências climáticas: de inverno e de primavera. Ambos podem manifestar sensibilidade ou insensibilidade ao fotoperíodo. Trigos de inverno têm um considerável requerimento em relação à vernalização, mas trigos de primavera podem ser insensíveis ou apenas parcialmente sensíveis à vernalização. No entanto, entre ambos os grupos, encontram-se tipos intermediários (semi-inverno, alternativo e facultativo) caracterizados por forte fotossensibilidade e parcial sensibilidade à vernalização (Stelmarkh, 1998).

Os trigos de primavera, insensíveis ao fotoperíodo e sem exigências em vernalização, destacam-se pela adaptação aos mais variados ambientes. Essa 
característica é típica de trigos oriundos do programa de melhoramento genético do Centro Internacional de Melhoramento de Milho e Trigo (Cunha et al., 1999).

No Instituto Agronômico (IAC), mediante cruzamento entre cultivares de origem mexicana e aqueles nacionais, tipo de primavera, tem-se procurado desenvolver cultivares mais adaptados às condições brasileiras de clima e solo (Camargo et al., 1990; 1991a).

Em relação ao ciclo, da emergência à maturação, os cultivares de trigo para o Estado de São Paulo são classificados em: a) precoce, com maturação até 120 dias; b) intermediário, com maturação entre 121 e 135 dias; e c) tardio, com maturação acima de 136 dias após a emergência (IAC, 1999).

Mediante estudos realizados por Camargo, M. B. P. de et al. (1985), em oito locais, representando diferentes regiões paulistas, por um período que variou de 19 a 34 anos, concluíram, em função da disponibilidade hídrica, que a melhor época para a semeadura de trigo, em condição de sequeiro, era de 11 de março a $1^{\circ}$ de abril para a região Sudeste, representada por Capão Bonito.

Felício et al. (1988), avaliando genótipos de trigo agrupados, quanto ao ciclo da emergência à maturação, em: precoce, médio e tardio, em três épocas de semeadura ( $3^{o}$ decêndio de março; $2^{o}$ decêndio de abril e $3^{o}$ decêndio de maio), em condição de sequeiro, na região de Capão Bonito, de 1981 a 1985, observaram que a primeira época foi a melhor, concordando com os estudos de Camargo, M. B. P. de et al. (1985).

Os genótipos de ciclo precoce são os mais indicados, no Estado de São Paulo, para a semeadura em condição de sequeiro. A realizada no final de março é mais favorável, porque há disponibilidade hídrica adequada no solo para suprir-lhe as necessidades. Os genótipos de ciclo médio e tardio, semeados nessa época, poderiam não ter suas exigências hídricas satisfeitas, principalmente se não ocorressem chuvas no período florescimento-enchimento de grãos. O florescimento mais precoce favorece a fuga do período de provável geada e o menor tempo no campo expõe os genótipos por menor período ao ataque de moléstias.

Camargo et al. (1999), avaliando genótipos diaplóides de trigo de ciclo médio, em 1995, observaram uma produção 30\% menor em condição de sequeiro quando comparados com a de irrigação. Em regiões cuja semeadura é efetuada sob irrigação, os 
genótipos de ciclo médio são os mais indicados. Nessas condições, não há limitação quanto às necessidades hídricas, e os genótipos podem ser semeados em épocas mais tardias, com temperaturas mais favoráveis, e permanecer no campo por um período maior a fim de promover o enchimento de grãos. Deve-se observar, porém, que o período de colheita não coincida com o chuvoso.

\subsubsection{Comprimento da espiga}

Trabalhos de avaliação de linhagens de trigo mostraram grande variabilidade para o caráter comprimento da espiga (Camargo, 1984 e Camargo et al., 1989, 1990, 1999). As linhagens IAC-147 (10,3 cm), IAC-150 (9,7 cm), IAC-152 (9,3 cm) e IAC-143 $(9,2 \mathrm{~cm})$ apresentaram as espigas as mais compridas, e a IAC-158 $(6,5 \mathrm{~cm})$ as mais curtas (Camargo et al., 1989).

Camargo et al. (1989), avaliando o comportamento de linhagens originárias do cruzamento entre os trigos de inverno e os de primavera no Estado de São Paulo, sugeriram que a linhagem IAC-147 $(10,3 \mathrm{~cm})$ poderia ser utilizada em programas de melhoramento como fonte genética para aumentar o comprimento da espiga. Da mesma forma, os cultivares IAC-5, Tordo e Siete Cerros mostraram-se eficientes em transmitir essa característica às suas progênies (Camargo et al., 1983).

Correlações fenotípicas positivas entre produção de grãos e comprimento da espiga foram observadas nos cruzamentos C-3 x Siete Cerros, C-3 x Tordo, C-3 x Olesen e C-3 x Vican-71 (Camargo et al., 1984), indicando que seria possível conseguir um aumento na produção mediante a seleção de genótipos com espigas mais compridas.

\subsubsection{Componentes de produção}

Segundo Medeiros \& Schlehuber (1971), o estudo da produção de grãos, em trigo, deve ser feito por meio de seus componentes (número de espigas férteis e de grãos por espiga e massa de grãos), uma vez que são herdados mais simplesmente que a própria produção.

Trabalhos envolvendo o estudo dos componentes de produção indicam a existência de sua grande variabilidade (Camargo et al., 1984; 1999 e Medeiros \& Schlehuber, 1971). 
Diversos genótipos poderiam ser utilizados como fontes genéticas para o melhoramento dos componentes de produção, como as linhagens IAC-142, 17 (Alondra-1 x IAC-5) e IAC-182 visando aumentar o número de espiguetas por espiga (Camargo \& Ramos, 1989 e Camargo et al., 1990 e 1991b respectivamente), e 20 (S-148 x Pichihuila), 10 (Jupateco x IAC-13), 17 (Alondra-1 x IAC-5) e Anahuac (Camargo et al., 1988; 1989; 1990 e 1991b respectivamente) para aumentar o número de grãos por espiga. Com o objetivo de melhorar a massa de grãos foram indicadas as linhagens IAC-157, 5 (Tobari-66 x BH-1146) e IAC-188 (Camargo et al., 1989; 1990 e 1991b respectivamente).

As massas dos grãos das variedades de trigo apresentam grande variação. Camargo et al. (1999), pesquisando uma série de linhagens, encontraram a massa média de cem grãos variando de 3,80 até 4,21 gramas. Medeiros \& Schlehuber (1971), estudando, 30 variedades de trigo, obtiveram como massa média de mil grãos $33,77 \mathrm{~g}$ $(26,39$ a $43,35 \mathrm{~g})$.

Wahhabe \& Husshain (1957) verificaram que a massa de mil grãos aumentou significativamente com a aplicação de nitrogênio. Entretanto, Volke \& Inostruza (1967) observaram efeito negativo do nitrogênio e positivo do fósforo sobre a massa dos grãos.

Segundo Robins \& Domingo (1962), tal massa foi altamente reduzida por deficiência de umidade antes da maturação, e conforme Weibel \& Pendleton (1964), o acamamento resultou em seu grande decréscimo.

O rendimento do trigo está correlacionado, positivamente, com o número de espigas por área e, o número de espigas, negativamente correlacionado com o de grãos por espiga (Volke \& Inostruza, 1967).

Medeiros \& Schlehuber (1971), em 1966, trabalhando com trinta variedades de trigo, em Pelotas (RS), obtiveram correlações positivas significativas de produção de grãos com número de espigas por parcela e de grãos por espiga.

\subsection{Produção de grãos}

O principal objetivo no melhoramento genético das culturas, na maioria das vezes, é a melhoria da produção de grãos. No entanto, esse é um caráter de regulação 
poligênica, muito influenciado pelo ambiente e, normalmente, de baixa herdabilidade (Camargo, et al., 1998 e Medeiros \& Schlehuber, 1971).

Tendo em vista a complexidade da produção de grãos, Medeiros \& Schlehuber (1971) sugerem que se faça seu estudo por meio de seus componentes (número de espigas férteis e de grãos por espiga e massa de grãos), uma vez que esses são herdados mais simplesmente que a produção. Sugerem, ainda, cautela na interpretação de tal informação, ao elaborar as conclusões gerais.

Johnson et al. (1966) concluíram que os componentes de produção são meros indicadores dos processos fisiológicos e metabólicos das plantas e, portanto, de pouca utilidade para os melhoristas, o que não se dá com a produção. Esta é o resultado, porém, de seus componentes que fornecem pequenas informações específicas.

Em programas de melhoramento, quando o objetivo principal é aumentar a produtividade, a seleção deverá ser dirigida a componentes intimamente relacionados com a produção de grãos. Assim, é de grande importância o conhecimento dos componentes de produção, do seu controle genético e de como estão relacionados.

A associação entre os componentes de produção e destes com as características agronômicas tem sido verificada em vários trabalhos. Segundo Tavella et al. (1987), a altura da planta e a massa de mil grãos estão positivamente associadas com altos rendimentos.

Camargo et al. (1998), estudando cruzamentos entre o cultivar IAC-227 ( $\left.\mathrm{P}_{1}\right)$, de origem nacional, e as linhagens de origem mexicana CMH78.390/CMH77A.917// CMH.215 $\left(\mathrm{P}_{2}\right)$, CMH79.959/2*CNO79 $\left(\mathrm{P}_{3}\right)$, CMH79.481/CMH77A.917 $\left(\mathrm{P}_{4}\right)$ e $\mathrm{CMH}$ 80A.747 $\left(\mathrm{P}_{5}\right)$ obtiveram correlações positivas e significativas entre produção de grãos e número de espigas por planta, em todos os cruzamentos entre o cultivar IAC-227 com as linhagens mexicanas, e para produção de grãos com número de grãos por espiga e com massa de cem grãos nos cruzamentos $\mathrm{P}_{1} \times \mathrm{P}_{2}$ e $\mathrm{P}_{1} \times \mathrm{P}_{4}$.

Camargo et al. (1994), avaliando linhagens e cultivares de trigo em diferentes regiões do Estado de São Paulo, em 1985, 1986 e 1987, obtiveram um ganho médio de $31 \%$ de produção dos genótipos cultivados em condição de irrigação por aspersão, quando comparados com os mesmos genótipos em sequeiro. Quando se considerou 
apenas o cultivar IAC-24, nas localidades de Maracaí (condição de sequeiro) e Monte Alegre do Sul (condição de irrigação), em 1985, essa diferença chegou a 43\%.

\subsection{Moléstias}

\subsubsection{Ferrugem-da-folha}

Segundo Mehta (1978), entre as moléstias de maior importância para a produção do trigo, encontra-se a ferrugem-da-folha, a mais disseminada em todo o mundo (Weise, 1977). No Brasil, é generalizada causando infecção em todas as safras nas mais diferentes regiões tritícolas (Barcellos, 1982). A intensidade de sua ocorrência e o conseqüente prejuízo variam de acordo com as condições climáticas da região de cultivo e com as variedades semeadas (Barros, 1985 e Goulart \& Paiva, 1992).

A obtenção de variedades resistentes é bastante dificultada, em face da alta especialização e da existência de grande número de raças fisiológicas do fungo (Barcellos, 1982 e Picinini \& Prestes, 1985).

$\mathrm{O}$ agente causal da ferrugem-da-folha é o fungo Puccinia recondita f. sp. tritici Rob. Desm., e que, apesar da denominação, pode atacar todas as partes da planta, desde a fase de plântula até o final do ciclo (Mehta, 1978).

Os sintomas característicos da moléstia são pústulas arredondadas ou ovaladas, cor de laranja, podendo espalhar-se por toda a parte aérea da planta e dispostas, preferencialmente, na face superior da folha. Tais pústulas contêm grande quantidade de esporos, os quais, transportados pelo vento, constituem fonte de infecção (Cardoso \& Kimati, 1980; Mehta, 1978 e Picinini \& Prestes, 1985).

Peterson (1965) considera que, apesar de ocorrer em todas as regiões produtoras de trigo, a moléstia mostra-se mais destrutiva em regiões temperadas e subtemperadas e nas estações úmidas de regiões secas.

O aparecimento da ferrugem-da-folha depende da suscetibilidade do hospedeiro, da existência da fonte de inóculo e de condições climáticas favoráveis, pois requer baixas temperaturas para seu desenvolvimento, o que condiciona seu aparecimento a partir da fase de perfilhamento e se estende até o final do ciclo, no Sul do Brasil (Picinini \& Prestes, 1985). 
A temperatura é um dos fatores ambientais de maior influência sobre o patógeno responsável pela ferrugem-da-folha, além de afetar o hospedeiro e a interação patógeno x hospedeiro (Broes \& Wallenburg, 1989). A resistência do hospedeiro parece diminuir com o aumento da temperatura; além disso, o estádio fenológico do hospedeiro constitui outro fator de influência sobre o desenvolvimento da moléstia. À medida que a cultura amadurece, maior a sua incidência (Burleigh et. al., 1972).

O prejuízo causado pela ferrugem-da-folha não é geralmente tão grande como o provocado por uma severa infestação de ferrugem-do-colmo. Redução de 5 a 10\% da produção é mais comum, em anos de severa ocorrência, porém, durante os primeiros estádios de desenvolvimento, podem matar as plantas novas (Poehlman, 1959).

Burleigh et al. (1972) observaram reação linear entre a severidade da infecção de ferrugem-da-folha e a redução da produção de trigo. O cultivar Sonora 63, no Paraná, apresentou 42\% de decréscimo na produção de grãos (Mehta \& Igarashi, 1979). Em experimento de campo, no Rio Grande do Sul, a moléstia provocou redução do número de grãos por espiga, massa de mil grãos e peso do hectolitro (Barcellos \& Ignaczak, 1978).

Goulart \& Paiva (1992) obtiveram um coeficiente de correlação negativo, altamente significativo, entre a incidência de ferrugem-da-folha e o rendimento, a massa de mil grãos e do peso do hectolitro, indicando que tais parâmetros foram prejudicados pela incidência da ferrugem.

Camargo et al. (1989) avaliaram 24 linhagens de trigo em condição de casa de vegetação e laboratório, para a reação ao agente causal da ferrugem-da-folha, verificando o destaque das linhagens IAC-143 e IAC-150 como resistentes às três misturas contendo diferentes raças do referido agente. Camargo et al. (1990) também destacaram a linhagem 21 (IAC-5 x ALONDRA S-46) por apresentar-se resistente às misturas 1 e 3 das mesmas raças do fungo, sugerindo que essa linhagem poderia ser utilizada como fonte genética em programas de melhoramento.

As linhagens diaplóides de trigo 1, 5 e 6, provenientes do cruzamento IAS-63/ ALDAN"S"//GLEN/3/IAC-24, apresentaram imunidade ao agente causal da ferrugem-da-folha, e as linhagens 2 (HAHN"S"*2/PRL"S"//IAC-24), 8, 10, 14 e 15, 
oriundas do cruzamento IAS-63/ALDAN"S"//GLEN/3/IAC-24, reação tS (apenas algumas pústulas), quando avaliadas em condição de campo (Camargo et al., 1999).

\subsubsection{Mancha-da-folha}

O fungo causador da mancha-da-folha, Helminthosporium sativum Pammel, King \& Bakke (Reis et al., 1987) sin. Bipolaris sorokiniana Sacc. ex. Sorok (Goulart et al., 1995), está largamente distribuído em todo o País, principalmente nas regiões de clima mais quente e úmido (Mehta, 1978).

A incidência da moléstia pode surgir em qualquer estádio de desenvolvimento da planta, causando manchas nas folhas, que se apresentam com bordos difusos e coloração marrom, variando de pardo-escura a preta, circundadas por um halo amarelo. Quando o ataque se dá em fase inicial de desenvolvimento, pode causar a morte prematura da planta (Cardoso \& Kimati, 1980; Mehta, 1978 e Picinini \& Prestes, 1985).

Aparece em zonas quentes e úmidas, podendo causar elevadas perdas, em virtude de sobreviver em restos de plantas por vários anos, o que dificulta seu controle, sobretudo em áreas onde se utiliza a semeadura direta (Mehta, 1978). Além de sobreviver em restos culturais, o fungo também pode ser transmitido por meio de sementes infectadas (Forcelini \& Reis, 1988 e Vechiato et al., 1987).

As linhagens de trigo 5 e 23, oriundas, respectivamente, dos cruzamentos PEL 14933-64 x IAC-5 e IAS-20(4) x IRN 152-63, destacaram-se pela moderada resistência ao Helminthosporium sativum, quando avaliadas no município de Capão Bonito, em condição de sequeiro, em 1986 (Camargo et al., 1988).

Em Cruzália (condição de sequeiro), as linhagens de trigo avaliadas em 1996-98 mostraram área foliar infectada por mancha-da-folha, variando de 10 a 90\%. O ano de 1997 foi o de sua maior incidência, quando se destacou a linhagem 21, com um grau máximo de infecção de $20 \%$, sendo considerada moderadamente resistente (Camargo et al., 1990). 


\subsubsection{Oídio}

O oídio pode ocorrer em quase todas as áreas tritícolas do mundo, com danos mais severos nas regiões de clima temperado. No Brasil, onde é muito importante, sua severidade varia muito de estação para estação (Linhares et al., 1988 e Picinini \& Prestes, 1985).

Causado pelo fungo Erysiphe graminis f. sp. tritici Marchal (Linhares, 1988b), é caracterizado por formação de um mofo variando de branco a cinza, em toda a parte aérea da planta, porém somente atacando tecido vivo, que, após o ataque, morre, provocando o declínio da planta (Linhares, 1982 e Mehta, 1978).

O prejuízo causado por oídio deve-se mais à intensidade de ataque do que à sua freqüência; a intensidade depende das condições ambientais (Ge et al., 1998; Linhares, 1982, 1988a e Linhares \& Ignaczak, 1978).

Ao contrário de outros patógenos, o oídio não apresenta um fator crítico ambiental, adaptando-se bem tanto a verões quentes como a invernos frios. $\mathrm{Na}$ generalização de que a moléstia é mais severa em condições de seca, deve-se levar em consideração que o orvalho e a irrigação podem, tanto quanto a chuva, aumentar a umidade do ambiente, favorecendo o patógeno (Linhares et al., 1988). A água aplicada por aspersão, além de provocar alterações no microclima, supre a umidade requerida para a infecção (geminação e penetração) de numerosos patógenos, favorecendo, também, a dispersão de esporos.

Sentelhas et al. (1993), estudando o efeito da irrigação e da densidade de semeadura sobre o oídio, observaram que a alteração no microclima, provocada por esses fatores, contribui de forma progressiva ao desenvolvimento do oídio, isto é, quanto mais densa e mais úmida a parcela, maior a incidência da moléstia.

As perdas de produção provocadas por oídio chegam a 55\%, quando comparadas às produções de ensaios que receberam tratamento com fungicidas a partir do perfilhamento (Linhares, 1988a).

As linhagens 11 (LILIFEN/MAGPIE) e 14 (SAWA/4/TEZANOS PINTOS PRECOZ//IRN 46/CIANO/3/PROTOR) mostraram-se resistentes e a 16 (CAPPELLE DESPREZ/2*PULLMAN 101//PAVON 76) e a 19 (STEPHENS/MCDERMID//CAMA /3/CIANO/SIETE CERROS//CORRECAMINOS /TOBARI) moderadamente resistente 
ao agente causal do oídio, quando avaliadas em condição de campo (Camargo et al., 1994).

\subsection{Tolerância à toxicidade ao alumínio}

Os solos brasileiros, na maioria, são bastante lixiviados, pobres e de elevada acidez. Associada a essas características, encontra-se, com freqüência, alta concentração de alumínio provocando toxicidade em muitas plantas cultivadas (Olmos \& Camargo, 1976).

A técnica geralmente empregada para corrigir tal problema é a calagem, que diminui a acidez do solo, aumentando a disponibilidade de nutrientes. Entretanto, essa correção se limita à camada superficial, restringindo o crescimento radicular ao horizonte superficial, limitando a absorção de água e nutrientes dos horizontes inferiores, provocando perda de rendimento e aumentando os danos decorrentes de veranicos (Alves et al., 1988 e Rosa et al., 1994).

Alternativa para diminuir os problemas da toxicidade de alumínio e a redução causada na produtividade das culturas é o melhoramento genético visando à obtenção de cultivares com elevada tolerância a altos níveis de alumínio (Brauner \& Sarruge, 1980; Camargo et al., 1990, 1991b e Rosa et al., 1994).

Os programas de melhoramento devem envolver a seleção em ampla variabilidade de material genético dentro da espécie, a determinação da natureza da tolerância e a combinação desta com outras características desejáveis, visando obter uma variedade superior para aquela condição particular de solo.

A presença do alumínio interfere na absorção e translocação de fósforo, bem como nos teores de cálcio, zinco e manganês na parte aérea, e de fósforo, magnésio e ferro no sistema radicular (Alves et al., 1988). A redução da produção e o acúmulo de matéria seca, quer por efeito direto, quer indireto no aproveitamento do fósforo foi observada por Zanata \& Mundstock (1988).

A restrição do crescimento radicular diminui a produção de grãos, a altura da planta e o número de perfilhos (Camargo \& Oliveira, 1981).

A tolerância à toxicidade de alumínio é um fator importante para garantir bom desenvolvimento do sistema radicular do trigo, em solos ácidos, permitindo a obtenção 
de água em maiores profundidades na seca, onde cultivares sensíveis não sobreviveriam, dada a inibição no crescimento radicular provocada pelo alumínio, além da camada superficial, quase sempre corrigida pela prática da calagem (Camargo \& Oliveira, 1981).

Camargo (1981), avaliando cruzamentos entre os cultivares BH-1146 (tolerante a $10 \mathrm{mg} \mathrm{L}^{-1}$ ), Atlas (tolerante a $6 \mathrm{mg} \mathrm{L}^{-1}$ ), Tordo (tolerante a $2 \mathrm{mg} \mathrm{L}^{-1}$ ) e Siete Cerros (sensível a $2 \mathrm{mg} \mathrm{L}^{-1}$ ), em solução nutritiva, observou que o 'BH-1146' diferiu dos demais por um par de genes dominantes, para a tolerância à toxicidade de alumínio, o qual foi eficiente a $10 \mathrm{mg} \mathrm{L}^{-1}$, sugerindo que esse cultivar, entre os estudados, foi a melhor fonte de tolerância para estudo em altas concentrações de alumínio.

Altos valores de herdabilidade no sentido restrito para a tolerância ao alumínio foram estimados em população proveniente do cruzamento entre os cultivares Siete Cerros (sensível) e C-3 (tolerante) (Camargo, 1984) e para as populações oriundas dos cruzamentos entre BH-1146 (tolerante) e os cultivares Alondra S-46 e IAC-17 (moderadamente tolerantes) (Camargo, 1987), indicando que grande parte da variabilidade genética total para essa característica está associada à ação aditiva dos genes, ou é devida a genes que se comportam de maneira aditiva. Os resultados indicam que a seleção para essa característica deveria ser realizada nas primeiras gerações após os cruzamentos.

Em populações provenientes de cruzamentos entre cultivares tolerantes e sensíveis à toxicidade ao alumínio, verificou-se que a tolerância a $6 \mathrm{mg} \mathrm{L}^{-1}$ não foi associada com altura da plantas (exceto para uma das populações estudadas), produção de grãos e número de grãos por espigueta, sugerindo que seria possível selecionar plantas tolerantes de porte médio com maior fertilidade da espiga e elevado potencial produtivo (Camargo, 1984).

A técnica empregada para o estudo da reação de cultivares de trigo ao alumínio tóxico baseia-se na paralisação irreversível do meristema das raízes primárias de trigo em estádio de plântula, utilizando soluções nutritivas em condição de laboratório (Camargo \& Oliveira, 1981 e Camargo et al., 1990, 1991ac).

O emprego de solução nutritiva para a identificação de genótipos de trigo tolerantes à toxicidade ao alumínio é rápida e eficiente, pois elimina a complexidade das interações entre o alumínio e demais nutrientes do solo, e permite a visualização do 
sistema radicular sem problemas; os resultados demonstram alta associação com as observações em campo em solo ácido (Camargo \& Oliveira, 1981 e Camargo et al., 1990).

Os cultivares Anahuac, sensível a $2 \mathrm{mg} \mathrm{L}^{-1}$, em solução nutritiva, produziu em solo ácido da Estação Experimental de Agronomia de Capão Bonito, em 1994-96, 192 $\mathrm{kg} \mathrm{ha}^{-1}$. Nas mesmas condições, o cultivar IAC-24, tolerante a $10 \mathrm{mg} \mathrm{L}^{-1}$, em solução nutritiva, produziu $1.209 \mathrm{~kg} \mathrm{ha}^{-1}$, sugerindo elevada associação entre os dados obtidos em condição de solo ácido e em condição de solução nutritiva, no laboratório (Tulmann Neto et al., 2001).

\subsection{Efeitos da geada sobre a cultura do trigo}

A perda de produtividade, por danos provocados por geadas é freqüentemente observada em diversas culturas e, segundo Camargo, M. B. P. et al. (1985), a ocorrência desse fenômeno é relativamente freqüente no Estado de São Paulo.

Estudando dados climatológicos coletados em diferentes regiões paulistas, durante vários anos, Camargo, M. B. P. et al. (1985) concluíram que a diferença entre a temperatura mínima registrada em abrigos meteorológicos era, na média, $4,1^{\circ} \mathrm{C}$ maior do que a obtida na relva.

Mota (1982) considera a temperatura de $-2^{\circ} \mathrm{C}$, como sendo o limite abaixo do qual os danos provocados pela geada já se fariam sentir na cultura do trigo, em vista das disfunções provocadas nos processos metabólicos da planta.

Segundo Scheeren (1982), embora baixas temperaturas, em determinados momentos, sejam desejáveis, o trigo é sensível às geadas, cujos danos tomam diferentes formas, dependendo do estádio de desenvolvimento da planta e da temperatura registrada durante a geada. Além da queima de folhas e estrangulamento de colmos, porém, o mais grave dano que a geada pode causar ao trigo é quando atinge os primórdios frutíferos, impedindo a formação dos grãos.

Avaliando o efeito da geada em trigo de inverno, Linvingston \& Swinbank (1949) observaram uma relação direta entre a quantidade de injúria na espiga com a temperatura e o tempo de exposição. Observaram, também, que a extensão dos danos poderia variar, dependendo do estádio de desenvolvimento em que se encontra a planta 
no momento da geada, ocorrendo as maiores injúrias durante o período de polinização, causando chochamento das espigas.

Segundo Lynch (1990), em revisão sobre as injúrias provocadas pelo resfriamento, essas não dependem somente da espécie ou tipo de tecido afetado, mas, também, da severidade e tempo de exposição a baixa temperatura, e que, além dessas, outras variáveis ambientais contribuem para a extensão da manifestação da injúria como conseqüência do resfriamento.

Campos et al. (2001), avaliando genótipos de trigo no Sul do País, verificaram a existência de variabilidade genética quanto à tolerância às geadas, e que a intensidade com que a cultura foi afetada pela geada dependeu de sua localização topográfica dentro do terreno e do estádio de desenvolvimento, sendo mais sensível por ocasião da emissão da espiga. Quando ocorre nos estádios de espigamento, até grão leitoso, há grande probabilidade de perdas totais. Esse dano pode ser comprovado pela mudança da coloração das espigas, que se tornam esbranquiçadas, e pelo estrangulamento de algumas partes do colmo. 


\section{MATERIAL E MÉTODOS}

\subsection{Origem das linhagens diaplóides de trigo}

Em 1997, realizaram-se no Instituto Agronômico (IAC), 1.687 cruzamentos entre cultivares de trigo adaptados às condições do Brasil, com alta tolerância ao alumínio, boa produtividade em solos ácidos e porte baixo, e cultivares de origem mexicana, de alto potencial produtivo e resistência às moléstias, principalmente ferrugem-da-folha e oídio, visando melhorar o potencial de produção do material brasileiro. Desses cruzamentos, escolheram-se 40 , semeando-se as sementes $F_{1}$ obtidas em vaso contendo solo devidamente corrigido e adubado, em condição de telado, em três épocas, empregando-se, em cada uma, cinco vasos por cruzamento. Em cada vaso, semeou-se uma semente para proporcionar melhor desenvolvimento da planta.

Quando as espigas das plantas dos cruzamentos em geração $F_{1}$ atingiram o tamanho equivalente a dois terços da bainha da folha bandeira e as aristas começavam e se evidenciar, elas foram coletadas, identificadas e levadas ao Laboratório de Cultura de Tecido do IAC. Lavaram-se as espigas com detergente comercial e desinfectaram-nas com uma solução de hipoclorito de sódio a $2 \%$, por trinta minutos, após três enxagües com água destilada deionizada. A seguir, armazenaram-nas em geladeira por um período não superior a uma semana, até posterior inoculação.

A inoculação das anteras foi realizada em câmara de fluxo laminar contínuo, em placas de Petri (9 $\mathrm{cm}$ de diâmetro), contendo, cada uma, $30 \mathrm{~mL}$ de meio de cultura "batata 2" (Moraes Fernandes, 1987). Em cada placa, colocaram-se somente anteras coletadas da mesma espiga, as quais foram identificadas com o registro da planta de origem. As placas foram, submetidas a tratamentos físicos como choque térmico a $5^{\circ} \mathrm{C}$, por três dias, acondicionamento em sala fotoperiódica com doze horas de luz (4.000 Lux) e temperatura de $25^{\circ} \mathrm{C}$, conforme Ramos et al. (1994), até que houvesse 
regeneração de estruturas androgenéticas. Em 1997, cerca de 120 mil anteras foram inoculadas.

Cerca de trinta dias após a inoculação, verificou-se o desenvolvimento de plântulas haplóides de algumas anteras. Em algumas placas, foi possível observar mais de uma antera produzindo estruturas androgenéticas, no entanto, a regeneração desse tipo de estrutura no referido ano ficou ao redor de $0,2 \%$ do total de anteras inoculadas. Outro detalhe relevante desse aspecto é quanto à diferença genética entre as plântulas regeneradas de anteras obtidas da mesma planta-mãe, isto é, cada antera, de uma mesma espiga, possui micrósporos, os quais poderão regenerar haplóides. No entanto, cada micrósporo apresenta um padrão genético diferente do outro: cada haplóide obtido, portanto, constitui um indivíduo geneticamente diferente.

Os haplóides obtidos, quando alcançaram bom desenvolvimento vegetativo, foram transplantados para vasos contendo solo corrigido e adubado sob condição de telado (com "sombrite" para a devida aclimatação). Das anteras inoculadas, obtiveram-se plântulas haplóides, as quais, após aclimatadas, foram levadas para um telado em condição natural, onde permaneceram até o início do perfilhamento. Nesse estádio de desenvolvimento, foram tratadas com solução de colchicina $(2,5 \%)$, por três horas, para que houvesse a duplicação cromossômica.

Após a duplicação, as plantas permaneceram em condição de telado até atingir a maturação, quando se realizou a colheita das espigas para a obtenção das sementes. Embora as plantas, agora diaplóides, possuíssem condições de produzir sementes, nem todas o fizeram, e, em alguns casos, chegaram a formar espigas, porém com todas ou algumas flores estéreis. Assim, as diaplóides, mesmo férteis, produziram pequeno número de sementes, o que poderia ser explicado pelo seu fraco desenvolvimento vegetativo.

As sementes, em pequeno número, obtidas das plantas duplicadas, foram multiplicadas em telado, recebendo, cada vaso, apenas uma semente. Na maturação, efetuaram-se algumas avaliações preliminares das características agronômicas (altura e ciclo) e aspecto geral da planta, descartando-se as que não apresentaram boas características. Das plantas restantes, selecionaram-se as melhores e com uma produção de sementes adequada para a avaliação nos Ensaios de Linhagens Diaplóides de Trigo I 
e II, estudadas no presente trabalho. As diaplóides com boas características, porém com pequena produção de sementes, foram postas em outro ensaio, incorporado ao programa de melhoramento do IAC para futuras avaliações e multiplicação de sementes.

Assim, cada tratamento foi composto por sementes produzidas a partir de uma planta diaplóide originada de uma única antera. A escolha de cada tratamento foi em função das boas características agronômicas expressas em condição de telado e da quantidade adequada de sementes que proporcionasse a avaliação em ensaios, com quatro repetições, em parcelas de 3,6 $\mathrm{m}^{2}$.

\subsection{Avaliação das linhagens diaplóides de trigo}

Dois ensaios, compostos cada um de 18 diferentes linhagens diaplóides de trigo provenientes de cultura de anteras e dois cultivares controles (IAC-24 e IAC-289), denominados Ensaios de Linhagens Diaplóides de Trigo I e II, foram instalados em dois locais do Estado de São Paulo, utilizando-se o delineamento estatístico de blocos ao acaso, com quatro repetições, em 1999 e 2000. Cada ensaio foi constituído de 80 parcelas, cada uma com de seis linhas de $3 \mathrm{~m}$ de comprimento, espaçadas de $0,20 \mathrm{~m}$.

A genealogia dos genótipos avaliados no Ensaio de Linhagens Diaplóides de Trigo I, instalado nas Estações Experimentais de Agronomia de Capão Bonito (Zona tritícola B - recomendação de época de semeadura: 20/3 a 31/5 solo ácido sem aplicação de calcário e em condição de sequeiro) e Tatuí (Zona tritícola D - recomendação de época de semeadura: 1\%/4 a 31/5 solo ácido com aplicação de calcário e em condição de irrigação por aspersão) e no Ensaio de Linhagens Diaplóides de Trigo II, instalado nas Estações Experimentais de Agronomia de Monte Alegre do Sul (Zona tritícola H - época de semeadura recomendada: $1^{\circ} / 4$ a 31/5, solo ácido com aplicação de calcário e em condição de irrigação por aspersão) e, Tatuí, em 1999 e 2000, é apresentada nas Tabelas 1 e 2 respectivamente. 
Tabela 1. Genealogia dos genótipos avaliados no Ensaio de Linhagens Diaplóides de Trigo I, nas Estações Experimentais de Agronomia de Capão Bonito e Tatuí em 1999 e 2000.

\begin{tabular}{|c|c|c|c|}
\hline Genótipos & $\begin{array}{l}\mathrm{N}^{\mathrm{o}} \mathrm{da} \\
\text { planta }\end{array}$ & Híbrido & Genealogia \\
\hline $1 \ldots \ldots \ldots \ldots . . . . .$. & 2460 & Н.20560 & JUN/GEN//IAC-24 \\
\hline $2 \ldots \ldots \ldots \ldots$ & 2461 & Н.20560 & JUN/GEN//IAC-24 \\
\hline $3 \ldots \ldots \ldots \ldots$ & 2462 & H.20558 & TEPOCA/IAC-24 \\
\hline 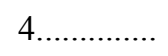 & 2470 & Н.20977 & PF70402/ALD“S”//PAT72160/ALD“S”/3/PEW“S”/4/OPATA/5/IAC-60 \\
\hline $5 \ldots \ldots \ldots \ldots . . . . .$. & 2470 & Н.20977 & PF70402/ALD“S”//PAT72160/ALD“S”/3/PEW“S”/4/OPATA/5/IAC-60 \\
\hline $6 \ldots \ldots \ldots$ & 2474 & Н.20976 & PF70402/ALD“S”//PAT72160/ALD“S”/3/PEW“S”/4/OPATA/5/IAC-60 \\
\hline $7 \ldots \ldots \ldots$ & 2485 & H.20550 & TRAP $1 * 2 / / E R P / R U S O / 3 / I A C-24$ \\
\hline $8 \ldots$ & 2488 & H.20552 & $\mathrm{PFAU} / 4 / \mathrm{BB} / \mathrm{GLL} / / \mathrm{CJ} / 3 / \mathrm{F} 35.70 / / \mathrm{KAL} / 5 / \mathrm{VEE} 7 / 6 / \mathrm{IAC}-24$ \\
\hline $9 \ldots$ & 2501 & Н.20409 & MRL”S”/BUC“S”//BUC“S”/3/IAC-24 \\
\hline $10 \ldots \ldots \ldots$ & 2521 & H.20553 & CS/A.CURV//GLEN/3/ALD/PVN/4/SUZ8/5/IAC-24 \\
\hline $11 \ldots \ldots \ldots \ldots . . . . .$. & 2556 & H.20558 & TEPOCA/IAC-24 \\
\hline $12 \ldots \ldots \ldots \ldots . . . . . .$. & 2557 & H.20558 & TEPOCA/IAC-24 \\
\hline $13 \ldots$ & 2563 & Н.20560 & JUN/GEN//IAC-24 \\
\hline $14 \ldots \ldots \ldots \ldots$ & 2580 & H.20976 & PF70402/ALD“S”//PAT72160/ALD“S”/3/PEW“S”/4/OPATA/5/IAC-60 \\
\hline $15 \ldots \ldots \ldots \ldots$ & 2581 & H.20976 & PF70402/ALD“S”//PAT72160/ALD“S”/3/PEW“S”/4/OPATA/5/IAC-60 \\
\hline $16 \ldots \ldots \ldots \ldots$ & 2582 & H.20976 & PF70402/ALD“S”//PAT72160/ALD“S”/3/PEW“S”/4/OPATA/5/IAC-60 \\
\hline $17 \ldots \ldots \ldots$ & 2605 & H.20526 & FURY-KEN/SLM//ALDAN/4/PAT10/ALD//PAT72300/3/PVN/4/IAC-24 \\
\hline 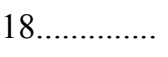 & 2626 & H.20558 & TEPOCA/IAC-24 \\
\hline 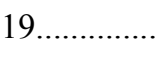 & & & IAS-51/IRN597-70 (IAC-24) \\
\hline $20 \ldots \ldots \ldots \ldots$ & & & KVZ/BUHO"S"//KAL/BLUEBIRD (IAC-289) \\
\hline
\end{tabular}


Tabela 2. Genealogia dos genótipos avaliados no Ensaio de Linhagens Diaplóides de Trigo II, nas Estações Experimentais de Agronomia de Monte Alegre do Sul e Tatuí em 1999 e 2000.

\begin{tabular}{|c|c|c|c|}
\hline Genótipos & $\begin{array}{l}\mathrm{N}^{\mathrm{o}} \mathrm{da} \\
\text { planta }\end{array}$ & Híbrido & Genealogia \\
\hline $1 \ldots \ldots \ldots \ldots . . . .$. & 2634 & H.20976 & PF70402/ALD“S”//PAT72160/ALD“S”/3/PEW“S”/4/OPATA/5/IAC-60 \\
\hline $2 \ldots \ldots \ldots \ldots . . . .$. & 798 & & ANA/IAC-24//IAC-24 \\
\hline $3 \ldots \ldots \ldots \ldots . . . .$. & 822 & & ANA/IAC-24//IAC-24 \\
\hline $4 \ldots \ldots \ldots \ldots . . . .$. & 843 & & ANA/IAC-24//IAC-24 \\
\hline $5 \ldots \ldots \ldots \ldots . . . .$. & 852 & & ANA/IAC-24//IAC-24 \\
\hline $6 \ldots \ldots \ldots$ & 859 & & ANA/IAC-24//IAC-24 \\
\hline $7 \ldots \ldots \ldots$ & 861 & & ANA/IAC-24//IAC-24 \\
\hline $8 \ldots \ldots \ldots$ & 865 & & ANA/IAC-24 \\
\hline $9 \ldots \ldots \ldots$ & 866 & & ANA/IAC-24 \\
\hline $10 \ldots \ldots \ldots \ldots$ & 868 & & ANA/IAC-24//IAC-24 \\
\hline 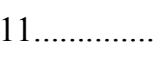 & 2480 & H.20526 & FURY-KEN/SLM//ALDAN/4/PAT10/ALD//PAT72300/3/PVN/5/IAC-24 \\
\hline $12 \ldots \ldots \ldots \ldots . . . .$. & 2574 & H.20605 & $\mathrm{JUP} / \mathrm{ZP} / / \mathrm{COC} / 3 / \mathrm{PVN} / 4 / \mathrm{GEN} / 5 / \mathrm{IAC}-24$ \\
\hline 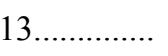 & 818 & & ANA/IAC-24//IAC-24 \\
\hline $14 \ldots \ldots \ldots \ldots$ & 2483 & H.20977 & PF70402/ALD“S”//PAT72160/ALD“S”/3/PEW“S”/4/OPATA/5/IAC-60 \\
\hline $15 \ldots \ldots \ldots \ldots$ & 2554 & H.20553 & CS/A.CURV//GLEN/3/ALD/PVN/4/SUZ8/5/IAC-24 \\
\hline $16 \ldots \ldots \ldots . .$. & 2558 & H.20558 & TEPOCA/IAC-24 \\
\hline $17 \ldots \ldots \ldots . .$. & 2598 & H.20977 & PF70402/ALD“S”//PAT72160/ALD“S”/3/PEW“S”/4/OPATA/5/IAC-60 \\
\hline $18 \ldots \ldots \ldots \ldots . . . .$. & 795 & & ANA/IAC-24//IAC-24 \\
\hline 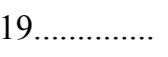 & & & IAS-51/IRN597-70 (IAC-24) \\
\hline $20 \ldots \ldots \ldots \ldots$ & & & KVZ/BUHO"S"//KAL/BLUEBIRD (IAC-289) \\
\hline
\end{tabular}


Em cada local, retiraram-se amostras compostas dos solos, na profundidade de 0-20 cm, visando às análises químicas efetuadas no Centro de Solos e Recursos Agroambientais do IAC, e cujos resultados se encontram na Tabela 3. A quantidade de fertilizante empregada $\left(\mathrm{N}, \mathrm{P}_{2} \mathrm{O}_{5}\right.$ e $\left.\mathrm{K}_{2} \mathrm{O}\right)$, nos diferentes ensaios, baseou-se nas tabelas de adubação do IAC em função das análises do solo (Raij et al., 1985).

Tabela 3. Resultados das análises químicas das amostras de solo $\left({ }^{1}\right)$, na profundidade de 0-20 cm, dos locais onde foram instalados os Ensaios de Linhagens Diaplóides de Trigo I e II em 1999 e 2000.

\begin{tabular}{|c|c|c|c|c|c|c|c|c|c|}
\hline \multirow{2}{*}{ Determinações } & \multicolumn{3}{|c|}{ Capão Bonito } & \multicolumn{3}{|c|}{ Monte Alegre do Sul } & \multicolumn{3}{|c|}{ Tatuí } \\
\hline & 1999 & 2000 & Média & 1999 & 2000 & Média & 1999 & 2000 & Média \\
\hline M.O. $\left(\mathrm{g} \mathrm{dm}^{-1}\right)$. & 26 & 26 & 26 & 14 & 20 & 17 & 25 & 23 & 24 \\
\hline $\mathrm{pH} \mathrm{CaCl} 2 \ldots \ldots \ldots$ & 4,2 & 4,3 & 4,3 & 5,3 & 5,3 & 5,3 & 4,6 & 5,0 & 4,8 \\
\hline P resina $\left(\mathrm{mg} \mathrm{dm}^{-3}\right)$. & 27 & 21 & 24 & 10 & 40 & 25 & 49 & 45 & 47 \\
\hline $\mathrm{K}\left(\mathrm{mmol}_{\mathrm{c}} \mathrm{dm}^{-3}\right) \ldots$. & 2,0 & 1,8 & 1,9 & 2,8 & 3,2 & 3,0 & 7,2 & 5,2 & 6,2 \\
\hline $\mathrm{Ca}\left(\mathrm{mmol}_{\mathrm{c}} \mathrm{dm}^{-3}\right) \ldots$ & 11 & 10 & 11 & 23 & 34 & 29 & 47 & 41 & 44 \\
\hline $\operatorname{Mg}\left(\mathrm{mmol}_{\mathrm{c}} \mathrm{dm}^{-3}\right) .$. & 2 & 2 & 2 & 8 & 10 & 9 & 13 & 12 & 13 \\
\hline $\mathrm{H}^{+}+\mathrm{Al}^{3+}\left(\mathrm{mmol}_{\mathrm{c}} \mathrm{dm}^{-3}\right)$ & 89 & 76 & 83 & 25 & 28 & 27 & 58 & 43 & 51 \\
\hline S.B. $\left(\mathrm{mmol}_{\mathrm{c}} \mathrm{dm}^{-3}\right) \ldots \ldots$ & 15 & 13 & 14 & 34 & 47 & 46 & 67 & 57 & 62 \\
\hline $\mathrm{CTC}\left(\mathrm{mmol}_{\mathrm{c}} \mathrm{dm}^{-3}\right) \ldots \ldots$ & 104 & 89 & 96 & 59 & 75 & 67 & 125 & 100 & 113 \\
\hline $\mathrm{V}(\%) \ldots$ & 14 & 15 & 15 & 57 & 63 & 60 & 53 & 58 & 56 \\
\hline
\end{tabular}

(1) Analises efetuadas pelo Centro de Solos e Recursos Agroambientais, do Instituto Agronômico (IAC), em Campinas (SP).

O cultivar IAC-24, utilizado como controle, caracteriza-se por apresentar ciclo intermediário da emergência à maturação, porte semi-anão, tolerância à toxicidade de alumínio, boa qualidade de panificação, média exigência em fertilidade do solo, média resposta à adubação nitrogenada, suscetibilidade ao agente causal de ferrugem-da-folha (IAC, 1996), e o 'IAC-289', ciclo de intermediário a tardio da emergência à maturação, porte semi-anão, moderada tolerância à toxicidade de alumínio, boa qualidade de panificação, alta exigência em fertilidade do solo, alta resposta à adubação nitrogenada, sensibilidade à germinação na espiga, suscetibilidade à ferrugem-da-folha (IAC, 1999). 
Efetuou-se a semeadura na base de oitenta sementes viáveis por metro linear de sulco, o que equivale a 1.440 sementes por parcela, com uma área útil de colheita de $3,6 \mathrm{~m}^{2}$.

Nesses ensaios, realizaram-se as seguintes avaliações:

Acamamento: considerando-se a porcentagem de plantas acamadas em cada parcela, por avaliação visual na época de maturação, empregando-se uma escala de 0 (sem acamamento) até $100 \%$ de plantas acamadas.

Altura da planta: medida, em centímetros, no campo, em três pontos de cada parcela, na época da maturação, do nível do solo ao ápice da espiga, excluindo-se as aristas.

Ciclo da emergência ao florescimento: contando-se o número de dias decorridos entre a emergência das plântulas e o florescimento (quando mais de $50 \%$ das espigas haviam florescido), nos ensaios instalados em Capão Bonito e Monte Alegre do Sul, em 1999 e 2000, e em Tatuí, em 2000.

Ciclo da emergência à maturação: anotando-se o número de dias decorridos entre a emergência das plântulas e a maturação de cada parcela (quando mais de 50\% apresentavam grãos maduros), classificando em precoce ( $<120$ dias), médio (121 a 130 dias) e tardio ( $>130$ dias).nos ensaios instalados em Capão Bonito e Monte Alegre do Sul, em 1999 e 2000, e em Tatuí, em 2000.

Comprimento da espiga: considerando-se o comprimento médio, em centímetros, de cinco espigas tomadas ao acaso em cada parcela, na maturação.

Número de espiguetas por espiga: computando-se o número médio de espiguetas de cinco espigas tomadas ao acaso em cada parcela.

Número de grãos por espiga: considerando-se o número médio de grãos de cinco espigas tomadas aleatoriamente em cada parcela.

Número de grãos por espigueta: calculando-se, mediante a divisão do número total de grãos pelo número total de espiguetas de cinco espigas coletadas de forma aleatória em cada parcela.

Massa de cem grãos: levando-se em conta a massa, em gramas, de grãos de cinco espigas tomadas ao acaso em cada parcela, e transformada para massa de cem grãos. 
Ferrugem-da-folha: na avaliação da resistência dessa moléstia, nas folhas superiores, no estádio de início de maturação, em condições naturais de infecção, empregou-se a escala modificada de Cobb (Schramm et al., 1974), ela vai de 0 a $100 \%$ da área foliar infectada, complementada pelo tipo de reação: $\mathrm{S}=$ suscetível (uredossoro grande, coalescente, sem necrose e sem clorose); MS = moderadamente suscetível (uredossoro médio); $\mathrm{M}=$ intermediária (diversos tipos de reação); $\mathrm{MR}=$ moderadamente resistente (uredossoro pequeno), e $\mathrm{R}=$ resistente (uredossoro minúsculo, rodeado por áreas necróticas). No Ensaio de Linhagens Diaplóides de Trigo II, instalado em 2000, em Monte Alegre do Sul, consideraram-se as folhas bandeiras.

Mancha-da-folha: na sua avaliação, em planta adulta, nas folhas superiores, em condições naturais de infecção, empregou-se a escala de 0 a 99\% de área foliar infectada, apresentada por Mehta (1978), onde 0 é considerado imune; de 1 a 5\%, resistente; de 6 a 25\%, moderadamente resistente; de 26 a 50\% suscetível, e de 51 a 99\%, altamente suscetível. No Ensaio de Linhagens Diaplóides de Trigo II, instalado em 2000, em Monte Alegre do Sul, nas avaliações consideraram-se as folhas bandeiras.

Oídio: sua avaliação foi idêntica à citada para mancha-da-folha.

Produção de grãos: considerando-se a produção total de grãos de cada parcela, transformada em $\mathrm{kg} \mathrm{ha}^{-1}$.

Os dados de produção de grãos, altura da planta, ciclos da emergência ao florescimento e da emergência à maturação (Capão Bonito e Monte Alegre, em 1999 e 2000, e Tatuí, em 2000), comprimento da espiga, número de espiguetas por espiga e de grãos por espiga e por espigueta e massa de cem grãos obtidos em cada ensaio instalado em diferentes locais, em 1999 e 2000, foram submetidos à análise da variância, utilizando-se o teste $\mathrm{F}$, a 5\%, para testar efeitos significativos de genótipos.

Analisaram-se as variâncias conjuntas para esses dados para cada grupo de ensaios, instalados em um mesmo local nos dois anos, detectando-se, pelo teste $\mathrm{F}$, a 5\%, as significâncias dos efeitos de genótipos, de anos e da interação genótipos $\mathrm{x}$ anos. Analisaram-se, também, as variâncias conjuntas para os mesmos dados obtidos, para cada grupo de ensaio independentemente de anos e locais, verificando-se, pelo teste $\mathrm{F}$, a $5 \%$, as significâncias dos efeitos de genótipos, de ensaios e da interação genótipos x ensaios. 
O teste de Tukey, a 5\%, foi empregado para a comparação das médias de genótipos em cada ensaio, ou grupo de ensaios.

Além das análises da variância, realizaram-se correlações entre produção de grãos, altura da planta e acamamento e entre produção de grãos e comprimento médio das raízes nas diferentes concentrações de alumínio, para os Ensaios de Linhagens Diaplóides de Trigo I e II. Nessas correlações, utilizaram-se as médias de cada um dos vinte genótipos avaliados em ambos os locais.

A tolerância à toxicidade ao alumínio dos genótipos estudados nos Ensaios I e II, foi avaliada em solução nutritiva, em condição de laboratório, empregando-se como controle as variedades BH-1146 (tolerante ao alumínio) e Anahuac (sensível). O método adotado para essas avaliações foi o descrito por Camargo \& Oliveira, 1981. As sementes dos vinte genótipos estudados no Ensaio de Linhagens Diaplóides de Trigo I e dos cultivares BH-1146 e Anahuac, usadas como controle, foram cuidadosamente lavadas com uma solução de hipoclorito de sódio a $10 \%$ e postas em caixas de Petri forradas com papel-filtro umedecido. As caixas permaneceram na geladeira por, aproximadamente, 24 horas para se obter uma germinação uniforme das sementes. Após esse período, foram colocadas sobre o balcão para que as sementes iniciassem a germinação. Quando as radículas ficaram visíveis, escolheram-se dez sementes uniformes de cada linhagem e seis de cada variedade controle, arrumando-as sobre cada uma das seis telas de náilon sobre potes plásticos, com 8,30 L de capacidade, contendo solução nutritiva, de modo que as sementes ficassem em contato com ela.

A concentração final da solução nos seis potes, que será referida como solução-base, foi a seguinte: $\mathrm{Ca}\left(\mathrm{NO}_{3}\right)_{2} 4 \mathrm{mM}$; $\mathrm{MgSO}_{4} 2 \mathrm{mM} ; \mathrm{KNO}_{3} 4 \mathrm{mM} ;\left(\mathrm{NH}_{4}\right)_{2} \mathrm{SO}_{4}$ 0,435 mM; $\mathrm{KH}_{2} \mathrm{PO}_{4}$ 0,5 mM; $\mathrm{MnSO}_{4} 2 \mu \mathrm{M} ; \mathrm{CuSO}_{4} 0,3 \mu \mathrm{M} ; \mathrm{ZnSO}_{4} 0,8 \mu \mathrm{M} ; \mathrm{NaCl} 30$ $\mu \mathrm{M}$; Fe-CYDTA $10 \mu \mathrm{M}$; $\mathrm{Na}_{2} \mathrm{MoO}_{4} 0,1 \mu \mathrm{M}$ e $\mathrm{H}_{3} \mathrm{BO}_{3} 10 \mu \mathrm{M}$. O nível da solução nas vasilhas plásticas foi tal de modo a tocar a parte inferior da tela de náilon, de maneira que as sementes fossem mantidas úmidas, tendo as radículas emergentes um pronto suprimento de nutrientes. O pH da solução foi previamente ajustado para 4,0 com $\mathrm{H}_{2} \mathrm{SO}_{4} 1 \mathrm{~N}$. As soluções foram continuamente aeradas e suas vasilhas plásticas colocadas em banho-maria com temperatura de $25 \pm 1^{\circ} \mathrm{C}$. O experimento foi mantido com luz artificial em sua totalidade. 
As plântulas desenvolveram-se nessas condições por 48 horas. Após esse período, cada qual apresentava três raízes primárias, uma mais longa e duas mais curtas, localizadas lateralmente à primeira.

Cada uma das seis telas de náilon com as plântulas dos genótipos estudados foi transferida para a solução-tratamento contendo um décimo da concentração da solução-base e as respectivas concentrações de alumínio $\left(0,2,4,6,8\right.$ e $\left.10 \mathrm{mg} \mathrm{L}^{-1}\right)$, exceto o fósforo que foi omitido para evitar possível precipitação do alumínio, e o ferro, adicionado em quantidade equivalente como $\mathrm{FeCl}_{3}$ no lugar de Fe-CYDTA. Por causa da possibilidade da precipitação do alumínio com $\mathrm{Al}(\mathrm{OH})_{3}$, especial atenção foi dada a esse ponto. Antes de transferir as telas para as soluções tratamento suficiente $\mathrm{H}_{2} \mathrm{SO}_{4} 1 \mathrm{~N}$ foi adicionado para trazer o $\mathrm{pH}$ para cerca de 4,2, colocando-se, então, a necessária quantidade de $\mathrm{Al}_{2}\left(\mathrm{SO}_{4}\right)_{3} \cdot 18 \mathrm{H}_{2} \mathrm{O}$. $\mathrm{O} \mathrm{pH}$ final foi ajustado para 4,0 com $\mathrm{H}_{2} \mathrm{SO}_{4} 1 \mathrm{~N}$, evitando-se adicionar $\mathrm{KOH}$, que poderia causar a precipitação do alumínio, pelo menos no local da queda da gota. As plântulas ficaram crescendo na solução-tratamento por 48 horas, quando foram transferidas novamente para a solução-base, a fim de que tivessem um meio adequado para retomar o desenvolvimento.

As plântulas permaneceram na solução-base por 72 horas. O crescimento da raiz, após esse período, dependeu da severidade prévia da solução-tratamento. Com as raízes das plantas sensíveis ao alumínio, ocorre uma injúria em sua extremidade e estas param de crescer; já com as raízes das plantas tolerantes, após a injúria causada pelo alumínio, ocorre novo surto de crescimento. A quantidade de crescimento da raiz após o efeito prejudicial do alumínio foi determinada, em cada uma das plântulas de cada genótipo, medindo-se o comprimento total da raiz primária central ao término das 72 horas de crescimento na solução-base e subtraindo-lhe o crescimento até a injúria provocada pelo alumínio. Este procedimento foi repetido cinco vezes para cada concentração.

O comprimento médio da raiz de cada genótipo foi representado pela média das dez plântulas avaliadas em cada concentração, nas cinco repetições.

O mesmo método foi utilizado para a avaliação da tolerância à toxicidade de alumínio dos genótipos estudados no Ensaio de Linhagens Diaplóides de Trigo II. 


\section{RESULTADOS E DISCUSSÃO}

\subsection{Ensaio de Linhagens Diaplóides de Trigo I}

O Ensaio de Linhagens Diaplóides de Trigo I foi instalado nas Estações Experimentais de Agronomia de Capão Bonito (solo ácido, sem aplicação de calcário e em condição de sequeiro) e Tatuí (solo ácido, com aplicação de calcário e em condição de irrigação por aspersão).

As diferenças existentes entre as duas condições de cultivo influenciaram todas as características avaliadas. Os genótipos semeados em Capão Bonito mostraram, na maioria das características, médias mais baixas, quando comparadas às de Tatuí, possivelmente em função da baixa fertilidade do solo e da elevada presença de alumínio (Tabela 3). A condição de sequeiro, foi outro fator que contribuiu para essa diferença.

Em Capão Bonito, em 2000, ocorreu menor disponibilidade hídrica em vista do menor volume de chuvas no período inicial de cultivo, obrigando ao uso da irrigação por aspersão, para que as plantas emergissem, mesmo considerando que, nesse local, o ensaio seria desenvolvido em condição de sequeiro (sem irrigação). Além da seca no início da cultura e geadas em julho, ocorreram chuvas na época de maturação e colheita, afetando negativamente o rendimento da cultura (Figura 1).

Em Tatuí, em julho de 2000, registraram-se temperaturas mínimas extremamente baixas durante as noites de $17\left(-1,4^{\circ} \mathrm{C}\right), 18\left(-1,2^{\circ} \mathrm{C}\right), 21\left(-2,0^{\circ} \mathrm{C}\right)$ e 22 $\left(-1,8^{\circ} \mathrm{C}\right)$ (Figura 2). As temperaturas mínimas na relva em Tatuí, nos dias 17 e 18 de julho de 2000 , ficaram em torno de $-7^{\circ} \mathrm{C}$. Nesse local, em 2000, houve também ocorrência de chuvas na época da maturação, prejudicando a produção de grãos do ensaio. 


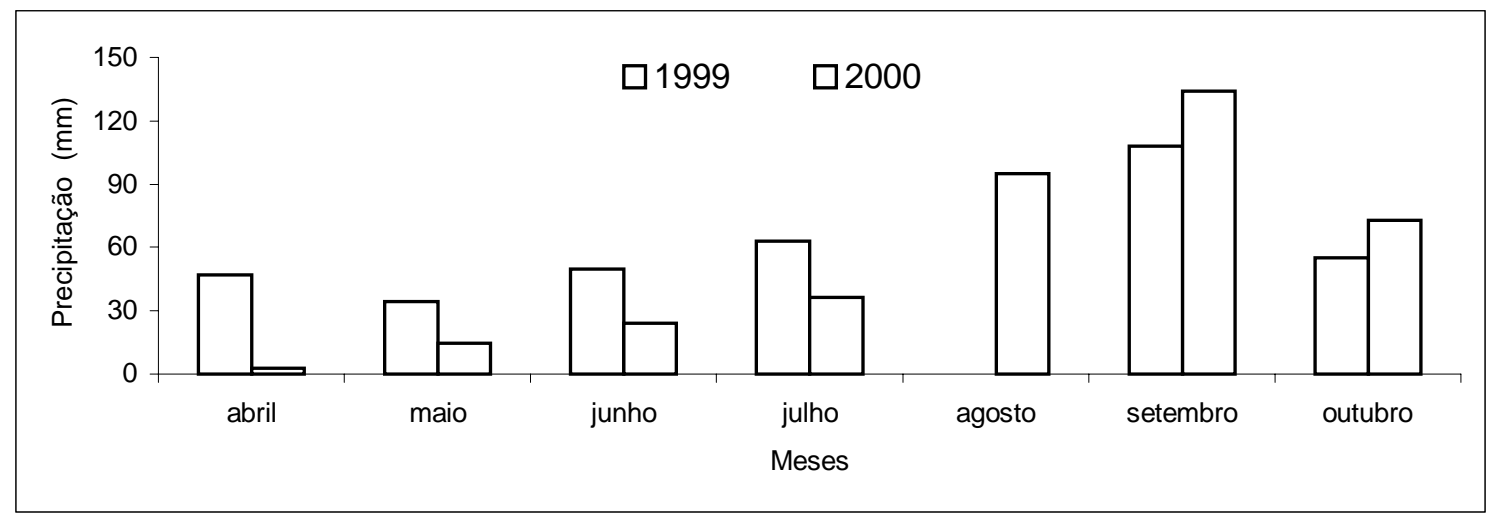

Figura 1 - Precipitações mensais de abril a outubro na Estação Experimental de Agronomia de Capão Bonito, em 1999 e 2000.

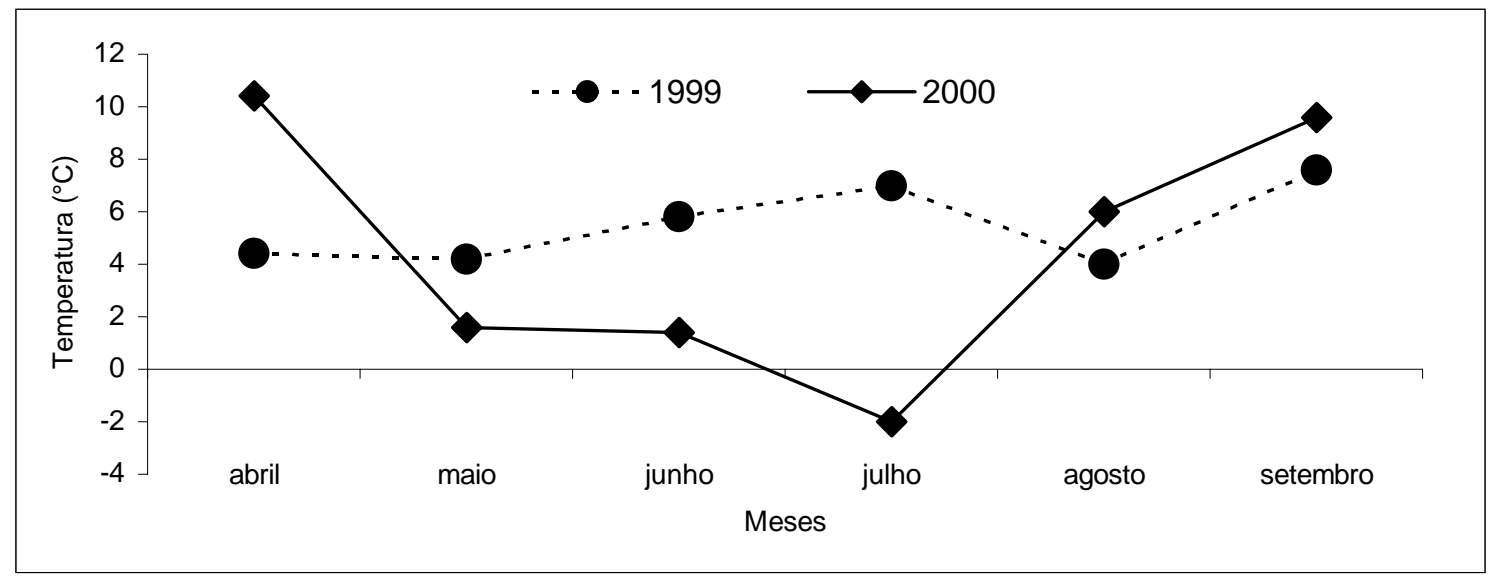

Figura 2 - Temperaturas mínimas mensais de abril a setembro na Estação Experimental de Agronomia de Tatuí, em 1999 e 2000. 
As produções médias de grãos dos genótipos avaliados nos Ensaios I, em Capão Bonito e Tatuí, em ambos os anos, encontram-se na Tabela 4. As produções obtidas em 2000 foram inferiores às alcançadas em 1999, principalmente em função das adversidades climáticas.

Levando-se em conta a análise da variância conjunta para produção de grãos dos quatro Ensaios de Linhagens Diaplóides de Trigo I, pode-se observar efeitos significativos de genótipos, de ensaios e da interação genótipos x ensaios. Essa interação indicou que os genótipos estudados apresentaram comportamento diferencial em relação aos ambientes em que foram avaliados. Apesar disso, a linhagem 13 mostrou as piores médias em todos os ensaios (Tabela 4).

Considerando-se as médias de produção de grãos dos genótipos avaliados nos quatro Ensaios I, as linhagens 4 (2.309 $\left.\mathrm{kg} \mathrm{ha}^{-1}\right), 5$ (2.319 $\left.\mathrm{kg} \mathrm{ha}^{-1}\right), 9$ (2.150 $\left.\mathrm{kg} \mathrm{ha}^{-1}\right), 11$ $\left(2.102 \mathrm{~kg} \mathrm{ha}^{-1}\right)$ e $12\left(2.056 \mathrm{~kg} \mathrm{ha}^{-1}\right)$ foram as mais produtivas, diferindo, porém, pelo teste de Tukey a 5\%, somente da linhagem $13\left(779 \mathrm{~kg} \mathrm{ha}^{-1}\right)$, a menos produtiva.

Os ensaios instalados em Capão Bonito, nos dois anos, em solo ácido e baixa fertilidade (Tabela 3) e em condição de sequeiro, quando analisados em conjunto, mostraram efeitos não significativos para genótipos e significativos para anos e para a interação genótipos $\mathrm{x}$ anos. $\mathrm{O}$ efeito de anos foi, principalmente, em função da deficiência hídrica do período inicial do ciclo em 2000, com uma produção média de $65,38 \%$ menor do que a obtida no ano anterior (Figura 1). A interação genótipos x anos indicou que a maioria dos genótipos avaliados não apresentou estabilidade de produção de grãos, isto é, tiveram um comportamento diferente em função do ano considerado (Tabela 4).

Na comparação das médias de produção de grãos, em Capão Bonito, em 1999, a linhagem 4, com $2.021 \mathrm{~kg} \mathrm{ha}^{-1}$ foi a mais produtiva, não diferindo, porém em $\mathrm{kg} \mathrm{ha}^{-1}$, dos genótipos 3 (1.733), 5 (1.778), 6 (1.865), 7 (1.674), 8 (1.768), 9 (1.802), 11 (1.625), 12 (1.861), 14 (1.854), 17 (1.688), 18 (1.636), 19 (1.497) e 20 (1.660). Em 2000, destacou-se a linhagem 9, com uma produção de $1.188 \mathrm{~kg} \mathrm{ha}^{-1}$, só não diferindo, em $\mathrm{kg} \mathrm{ha}^{-1}$, dos genótipos 3 (931), 10 (910), 15 (726), 16 (726), 18 (993) e 19 (792). 
Tabela 4. Produção de grãos dos genótipos avaliados no Ensaio de Linhagens Diaplóides de Trigo I, nas Estações Experimentais de Agronomia de Capão Bonito e Tatuí em 1999 e 2000.

\begin{tabular}{|c|c|c|c|c|c|c|c|}
\hline \multirow{3}{*}{ Genótipos } & \multicolumn{7}{|c|}{ Produção de grãos } \\
\hline & \multicolumn{3}{|c|}{ Capão Bonito } & \multicolumn{3}{|c|}{ Tatuí } & \multirow{2}{*}{$\begin{array}{l}\text { Média } \\
\text { geral }\end{array}$} \\
\hline & 1999 & 2000 & Média & 1999 & 2000 & Média & \\
\hline & \multicolumn{6}{|c|}{$\mathrm{kg} \mathrm{ha}^{-1}$} & \\
\hline ......... & $1232 \mathrm{~cd}$ & $490 \mathrm{c}-\mathrm{i}$ & 861 & $2201 \mathrm{~d}-\mathrm{g}$ & $1354 \mathrm{~d}-\mathrm{f}$ & $1778 \mathrm{ab}$ & $1319 a b$ \\
\hline $2 \ldots$ & $1410 \mathrm{~b}-\mathrm{d}$ & $431 \mathrm{~d}-\mathrm{i}$ & 920 & $2222 \mathrm{c}-\mathrm{g}$ & 1549 b-e & $1885 \mathrm{ab}$ & $1403 \mathrm{ab}$ \\
\hline $3 \ldots \ldots$. & $1733 a-c$ & $931 \mathrm{a}-\mathrm{c}$ & 1332 & $3833 \mathrm{ab}$ & 1215 ef & $2524 \mathrm{ab}$ & $1928 \mathrm{ab}$ \\
\hline $4 \ldots \ldots \ldots \ldots$ & $2021 \mathrm{a}$ & $681 \mathrm{~b}-\mathrm{g}$ & 1351 & $4118 \mathrm{ab}$ & $2417 \mathrm{a}$ & $3267 \mathrm{a}$ & $2309 \mathrm{a}$ \\
\hline $5 \ldots \ldots \ldots \ldots . . . . .$. & $1778 \mathrm{a}-\mathrm{c}$ & $625 \mathrm{~b}-\mathrm{h}$ & 1201 & $4583 \mathrm{a}$ & 2292 a-c & 3438 a & $2319 a$ \\
\hline $6 \ldots \ldots \ldots \ldots \ldots . . .$. & $1865 \mathrm{ab}$ & 410 e-i & 1137 & 3583 a-d & 1410 d-f & $2497 \mathrm{ab}$ & $1817 \mathrm{ab}$ \\
\hline 7....................... & $1674 \mathrm{a}-\mathrm{c}$ & $163 \mathrm{hi}$ & 918 & 3583 a-d & $2326 \mathrm{ab}$ & $2955 \mathrm{ab}$ & $1937 \mathrm{ab}$ \\
\hline $8 \ldots \ldots \ldots \ldots \ldots$. & 1768 a-c & 194 g-i & 981 & $2722 \mathrm{~b}-\mathrm{g}$ & 1139 ef & $1931 a b$ & $1456 \mathrm{ab}$ \\
\hline 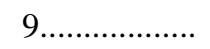 & $1802 \mathrm{a}-\mathrm{c}$ & $1188 \mathrm{a}$ & 1495 & 3472 a-e & 2139 a-d & $2806 \mathrm{ab}$ & $2150 \mathrm{a}$ \\
\hline $10 \ldots \ldots \ldots \ldots \ldots$ & $969 \mathrm{~d}$ & 910 a-e & 939 & $1799 \mathrm{fg}$ & 1299 d-f & $1549 \mathrm{ab}$ & $1244 \mathrm{ab}$ \\
\hline $11 \ldots \ldots \ldots \ldots \ldots \ldots$ & $1625 a-c$ & $542 \mathrm{~b}-\mathrm{i}$ & 1083 & $4459 \mathrm{a}$ & 1785 a-e & $3122 \mathrm{ab}$ & $2102 \mathrm{a}$ \\
\hline $12 \ldots \ldots \ldots \ldots \ldots$ & $1861 \mathrm{a}-\mathrm{c}$ & $260 \mathrm{f}-\mathrm{i}$ & 1061 & $4334 \mathrm{a}$ & $1771 \mathrm{a}-\mathrm{e}$ & $3052 \mathrm{ab}$ & $2056 \mathrm{a}$ \\
\hline $13 \ldots \ldots \ldots \ldots \ldots$ & $976 \mathrm{~d}$ & $63 \mathrm{i}$ & 519 & $1445 \mathrm{~g}$ & $632 \mathrm{f}$ & $1038 \mathrm{~b}$ & $779 \mathrm{~b}$ \\
\hline $14 \ldots \ldots \ldots \ldots$ & $1854 \mathrm{a}-\mathrm{c}$ & $288 \mathrm{f}-\mathrm{i}$ & 1071 & 3667 a-d & 1694 a-e & $2680 \mathrm{ab}$ & $1876 a b$ \\
\hline $15 \ldots \ldots \ldots \ldots$ & 1292 b-d & 726 a-f & 1009 & 3695 a-c & 1340 d-e & $2517 \mathrm{ab}$ & $1763 \mathrm{ab}$ \\
\hline $16 \ldots \ldots \ldots \ldots$ & $1386 \mathrm{~b}-\mathrm{d}$ & 726 a-f & 1056 & 3430 a-e & $1326 \mathrm{~d}-\mathrm{f}$ & $2378 \mathrm{ab}$ & $1717 \mathrm{ab}$ \\
\hline $17 \ldots \ldots \ldots \ldots \ldots \ldots$ & $1688 \mathrm{a}-\mathrm{c}$ & $448 \mathrm{c}-\mathrm{i}$ & 1068 & $1924 \mathrm{e}-\mathrm{g}$ & $1438 \mathrm{c}-\mathrm{f}$ & $1681 \mathrm{ab}$ & $1374 \mathrm{ab}$ \\
\hline $18 \ldots \ldots \ldots \ldots \ldots \ldots$ & $1636 a-c$ & $993 \mathrm{ab}$ & 1314 & $2604 \mathrm{~b}-\mathrm{g}$ & 1868 a-e & $2236 \mathrm{ab}$ & $1775 \mathrm{ab}$ \\
\hline $19 \ldots \ldots \ldots \ldots \ldots$ & 1497 a-d & 792 a-e & 1144 & 3653 a-d & $1479 b-f$ & $2566 \mathrm{ab}$ & $1855 \mathrm{ab}$ \\
\hline $20 \ldots \ldots \ldots \ldots \ldots$ & $1660 a-c$ & $125 \mathrm{i}$ & 892 & 3229 a-f & 1493 b-f & $2361 \mathrm{ab}$ & $1627 \mathrm{ab}$ \\
\hline F (Gen.) & $5,96 *$ & $11,24 *$ & 0,96 & $9,49 *$ & $7,48^{*}$ & $2,77 *$ & $2,82^{*}$ \\
\hline F (Anos) & - & - & $113,35^{*}$ & - & - & $94,68 *$ & - \\
\hline F (Ensaios) & - & - & - & - & - & - & $114,53 *$ \\
\hline$F(G \times A)$ & - & - & $7,53^{*}$ & - & - & $4,86^{*}$ & - \\
\hline$F(G \times E)$ & - & - & - & - & - & - & $6,09 *$ \\
\hline d.m.s. ${ }^{(1)}$ & 629 & 497 & 1253 & 1579 & 857 & 2153 & 1207 \\
\hline C.V. $(\%)$ & 15,10 & 34,49 & 21,03 & 18,63 & 20,43 & 19,91 & 21,55 \\
\hline
\end{tabular}

${ }^{(1)}$ Médias seguidas de, pelo menos, uma letra comum não diferem, entre si, pelo teste de Tukey.

* Significativo a $5 \%$. 
A análise da variância conjunta dos ensaios de Tatuí, nos dois anos, mostrou efeitos significativos para genótipos e anos, sugerindo que a queda de 50,49\% no rendimento de 2000 foi devida às diferenças ambientais entre os dois anos, sobretudo, às geadas de 2000, durante o ciclo da cultura. Também a interação genótipos x anos foi significativa, mostrando que eles exibiram um comportamento diferente em relação aos anos em que foram avaliados.

Considerando-se as médias de produção de grãos dos ensaios de Tatuí, destacaram-se as linhagens 4 e 5 (3.267 e $\left.3.438 \mathrm{~kg} \mathrm{ha}^{-1}\right)$ como as mais produtivas, somente diferindo, porém, da $13\left(1.038 \mathrm{~kg} \mathrm{ha}^{-1}\right)$, a menos produtiva (Tabela 4).

Em 1999, as linhagens 5 (4.583 kg ha $\left.{ }^{-1}\right), 11\left(4.459 \mathrm{~kg} \mathrm{ha}^{-1}\right)$ e 12 (4.334 $\mathrm{kg} \mathrm{ha}^{-1}$ ) destacaram-se como as mais produtivas, diferindo, porém, em $\mathrm{kg} \mathrm{ha}^{-1}$, das linhagens 1 (2.201), 2 (2.222), 8 (2.722), 10 (1.799), 13 (1.445), 17 (1.924) e 18 (2.604), menos produtivas. Já no ano seguinte, destacou-se a linhagem 4 (2.417), não diferindo, pelo teste de Tukey a $5 \%$, em $\mathrm{kg} \mathrm{ha}^{-1}$, das linhagens 5 (2.292), 7 (2.326), 9 (2.139), 11 (1.785), 12 (1.771), 14 (1.694) e 18 (1.868).

Na Tabela 5, encontram-se os dados de altura da planta dos genótipos do Ensaio de Linhagens Diaplóides de Trigo I, em Capão Bonito e Tatuí, em ambos os anos.

A análise da variância para altura da planta mostrou efeitos significativos para genótipos, para ensaios e para a interação genótipos x ensaios, quando avaliados em conjunto os quatro Ensaios I, indicando que os genótipos apresentaram comportamento diferente de acordo com o ambiente em que foram avaliados. Entretanto, a linhagem 13, com plantas mais baixas nos quatro ensaios, revelou-se, portanto, uma fonte genética para essa característica (Tabela 5). Sua baixa altura, porém mostrou-se associada à baixa produção de grãos.

Na comparação das médias de altura dos quatro ensaios, a linhagem $9(86 \mathrm{~cm})$ apresentou as plantas mais altas, diferindo apenas dos genótipos 7, 11, 13, 19 e 20, com altura entre 53 e $75 \mathrm{~cm}$. 
Tabela 5. Altura da planta dos genótipos avaliados no Ensaio de Linhagens Diaplóides de Trigo I, nas Estações Experimentais de Agronomia de Capão Bonito e Tatuí em 1999 e 2000.

\begin{tabular}{|c|c|c|c|c|c|c|c|}
\hline \multirow{3}{*}{ Genótipos } & \multicolumn{7}{|c|}{ Altura da planta } \\
\hline & \multicolumn{3}{|c|}{ Capão Bonito } & \multicolumn{3}{|c|}{ Tatuí } & \multirow{2}{*}{$\begin{array}{c}\text { Média } \\
\text { geral }\end{array}$} \\
\hline & 1999 & 2000 & Média & 1999 & 2000 & Média & \\
\hline & & & & $-\mathrm{cm}-$ & & & - \\
\hline $1 \ldots \ldots \ldots \ldots$ & $79 a b$ & $61 \mathrm{ab}$ & $70 a b$ & $100 \mathrm{a}-\mathrm{d}$ & $76 \mathrm{ab}$ & $88 \mathrm{a}$ & $79 \mathrm{a}-\mathrm{d}$ \\
\hline $2 \ldots \ldots \ldots \ldots$ & $79 a b$ & $60 \mathrm{ab}$ & $69 a b$ & $100 \mathrm{a}-\mathrm{d}$ & $78 \mathrm{ab}$ & $89 \mathrm{a}$ & 79 a-d \\
\hline 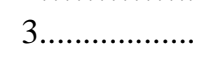 & $75 \mathrm{~b}$ & $65 \mathrm{ab}$ & $70 \mathrm{ab}$ & $93 \mathrm{de}$ & $69 \mathrm{~b}$ & $81 \mathrm{a}$ & $76 \mathrm{a}-\mathrm{d}$ \\
\hline $4 \ldots \ldots \ldots \ldots$ & $81 \mathrm{ab}$ & $68 \mathrm{a}$ & $74 a b$ & $108 \mathrm{a}$ & $77 \mathrm{ab}$ & $92 \mathrm{a}$ & $83 \mathrm{a}-\mathrm{c}$ \\
\hline $5 \ldots \ldots \ldots \ldots . . .$. & $88 \mathrm{a}$ & $68 \mathrm{a}$ & $78 \mathrm{a}$ & $106 \mathrm{a}-\mathrm{c}$ & $80 \mathrm{ab}$ & $93 \mathrm{a}$ & $85 \mathrm{ab}$ \\
\hline 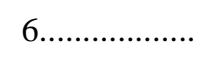 & $78 \mathrm{ab}$ & $61 \mathrm{ab}$ & $69 a b$ & $98 \mathrm{c}-\mathrm{e}$ & $69 \mathrm{~b}$ & $83 \mathrm{a}$ & $76 \mathrm{a}-\mathrm{d}$ \\
\hline 7..................... & $78 a b$ & $55 \mathrm{a}-\mathrm{c}$ & $66 a b$ & $93 \mathrm{de}$ & $72 \mathrm{ab}$ & $83 \mathrm{a}$ & $74 \mathrm{~cd}$ \\
\hline 8...................... & $81 \mathrm{ab}$ & $63 \mathrm{ab}$ & $72 a b$ & $107 \mathrm{ab}$ & $74 \mathrm{ab}$ & $90 \mathrm{a}$ & $81 \mathrm{a}-\mathrm{d}$ \\
\hline $9 \ldots \ldots \ldots \ldots \ldots$ & $81 \mathrm{ab}$ & $70 \mathrm{a}$ & $76 a b$ & $107 \mathrm{ab}$ & $85 \mathrm{a}$ & $96 a$ & $86 \mathrm{a}$ \\
\hline $10 \ldots \ldots \ldots \ldots \ldots \ldots$ & $75 \mathrm{~b}$ & $63 a b$ & $69 a b$ & 99 b-e & $66 \mathrm{bc}$ & $83 a$ & 76 a-d \\
\hline 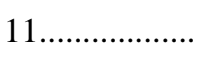 & $74 \mathrm{~b}$ & $61 \mathrm{ab}$ & $68 \mathrm{ab}$ & $93 \mathrm{de}$ & $73 a b$ & $83 \mathrm{a}$ & $75 \mathrm{~b}-\mathrm{d}$ \\
\hline $12 \ldots \ldots \ldots \ldots \ldots \ldots$ & $81 \mathrm{ab}$ & $56 \mathrm{a}-\mathrm{c}$ & $69 \mathrm{ab}$ & $94 \mathrm{de}$ & $73 \mathrm{ab}$ & $83 \mathrm{a}$ & $76 \mathrm{a}-\mathrm{d}$ \\
\hline $13 \ldots \ldots \ldots \ldots$ & $58 \mathrm{c}$ & $41 \mathrm{c}$ & $49 \mathrm{c}$ & $62 \mathrm{f}$ & $52 \mathrm{c}$ & $57 \mathrm{~b}$ & $53 \mathrm{e}$ \\
\hline $14 \ldots \ldots \ldots \ldots$ & $79 a b$ & $61 \mathrm{ab}$ & $70 a b$ & $106 \mathrm{a}-\mathrm{c}$ & $79 \mathrm{ab}$ & $93 \mathrm{a}$ & $81 \mathrm{a}-\mathrm{d}$ \\
\hline $15 \ldots \ldots \ldots \ldots$ & $78 \mathrm{ab}$ & $61 \mathrm{ab}$ & $69 a b$ & 99 b-e & $74 \mathrm{ab}$ & $86 \mathrm{a}$ & $78 \mathrm{a}-\mathrm{d}$ \\
\hline $16 \ldots \ldots \ldots \ldots$ & $78 a b$ & $63 \mathrm{ab}$ & $70 \mathrm{ab}$ & $100 \mathrm{a}-\mathrm{d}$ & $71 \mathrm{ab}$ & $85 \mathrm{a}$ & $78 \mathrm{a}-\mathrm{d}$ \\
\hline $17 \ldots \ldots \ldots \ldots \ldots$ & $81 \mathrm{ab}$ & $65 a b$ & $73 a b$ & 99 b-e & $68 \mathrm{~b}$ & $84 \mathrm{a}$ & 78 a-d \\
\hline $18 \ldots \ldots \ldots \ldots \ldots \ldots$ & $74 \mathrm{~b}$ & $69 \mathrm{a}$ & $71 \mathrm{ab}$ & $94 \mathrm{de}$ & $85 \mathrm{a}$ & $90 \mathrm{a}$ & $80 \mathrm{a}-\mathrm{d}$ \\
\hline $19 \ldots \ldots \ldots \ldots \ldots \ldots$ & $73 \mathrm{~b}$ & $68 \mathrm{a}$ & $70 a b$ & $91 \mathrm{e}$ & $66 \mathrm{bc}$ & $78 \mathrm{a}$ & $74 \mathrm{~cd}$ \\
\hline $20 \ldots \ldots \ldots \ldots \ldots \ldots$ & $74 \mathrm{~b}$ & $48 \mathrm{bc}$ & $61 \mathrm{bc}$ & $92 \mathrm{de}$ & $73 \mathrm{ab}$ & $82 \mathrm{a}$ & $72 \mathrm{~d}$ \\
\hline F (Gen.) & $5,88^{*}$ & $4,13^{*}$ & $4,34 *$ & $29,92 *$ & $6,50 *$ & $6,20 *$ & $10,16^{*}$ \\
\hline $\mathrm{F}($ Anos $)$ & - & - & $159,79 *$ & - & - & $273,81^{*}$ & - \\
\hline F (Ensaios) & - & - & - & - & - & - & $247,24 *$ \\
\hline$F(G \times A)$ & - & - & 1,76 & - & - & $3,11^{*}$ & - \\
\hline$F(G \times E)$ & - & - & - & - & - & - & $2,28 *$ \\
\hline d.m.s. ${ }^{(1)}$ & 13 & 18 & 16 & 9 & 15 & 19 & 11 \\
\hline C.V. (\%) & 6,26 & 11,28 & 8,61 & 3,72 & 7,89 & 6,12 & 7,25 \\
\hline
\end{tabular}

${ }^{(1)}$ Médias seguidas de, pelo menos, uma letra comum não diferem, entre si, pelo teste de Tukey.

* Significativo a $5 \%$. 
Considerando-se os ensaios de Capão Bonito, nos dois anos, a análise da variância mostrou efeitos significativos somente para genótipos e anos. O fato de não haver interação genótipos x anos indicou que, apesar da diferença entre os anos, os genótipos tenderam a apresentar o mesmo comportamento, isto é, os mais altos em 1999 também tenderam a ser os mais altos no ano seguinte.

Comparando-se as médias de altura da planta dos ensaios de Capão Bonito, em 1999 e 2000, a linhagem 5 (78 cm) exibiu as plantas mais altas, diferindo apenas, porém, dos genótipos 13 e 20 (49 e 61 cm).

Quando se consideraram em conjunto os ensaios instalados em Tatuí, em 1999 e 2000, a análise da variância exibiu efeitos significativos para genótipos, para anos e para a interação genótipos $\mathrm{x}$ anos, indicando um comportamento diferenciado dos genótipos em relação aos anos de avaliação.

A linhagem $13(57 \mathrm{~cm})$ exibiu as plantas mais baixas, diferindo das demais pelo teste de Tukey a 5\%, quando se levou em conta o conjunto dos ensaios de Tatuí em ambos os anos.

Em 1999, a linhagem $4(108 \mathrm{~cm})$ exibiu as plantas mais altas, não diferindo das linhagens $1,2,5,8,9,14$ e 16, com plantas de 100 a 107 cm. Já em 2000, as linhagens 9 e $18(85 \mathrm{~cm})$ foram as mais altas, diferindo somente dos genótipos 3, 6, 10, 13,17 e 19, com altura inferior a $70 \mathrm{~cm}$.

A correlação entre os dados médios dos genótipos avaliados nos quatro ensaios I, para produção de grãos e altura da planta, mostrou-se positiva e significativa $(\mathrm{r}=0,63 *)$, a $5 \%$, indicando uma tendência de as plantas mais altas exibirem as maiores produções, concordando com Camargo \& Oliveira (1983), que procuraram estimar a herdabilidade para várias características da planta e a associação entre elas em cruzamentos entre o cultivar IAC-5, de porte alto, e 'Tordo', 'Vican-71' e 'Olesen', de plantas anãs, e com Camargo (1987), estudando a associação entre produção de grãos e outras características agronômicas do trigo.

Os ciclos, em dias, da emergência ao florescimento e da emergência à maturação dos genótipos do Ensaio de Linhagens Diaplóides de Trigo I, em Capão Bonito, em 1999 e 2000, e em Tatuí, em 2000, acham-se na Tabela 6. 
Tabela 6. Ciclos da emergência ao florescimento e da emergência à maturação, em dias, dos genótipos avaliados no Ensaio de Linhagens Diaplóides de Trigo I, nas Estações Experimentais de Agronomia de Capão Bonito, em 1999 e 2000, e Tatuí em 2000.

\begin{tabular}{|c|c|c|c|c|c|c|c|c|c|c|}
\hline \multirow{3}{*}{ Genótipos } & \multicolumn{5}{|c|}{ Emergência-Florescimento } & \multicolumn{5}{|c|}{ Emergência-Maturação } \\
\hline & \multicolumn{3}{|c|}{ Capão Bonito } & \multirow{2}{*}{$\begin{array}{l}\text { Tatuí } \\
2000\end{array}$} & \multirow{2}{*}{$\begin{array}{l}\text { Média } \\
\text { geral }\end{array}$} & \multicolumn{3}{|c|}{ Capão Bonito } & \multirow{2}{*}{$\begin{array}{l}\text { Tatuí } \\
2000\end{array}$} & \multirow{2}{*}{$\begin{array}{c}\text { Média } \\
\text { geral }\end{array}$} \\
\hline & 1999 & 2000 & Média & & & 1999 & 2000 & Média & & \\
\hline & & & & & & & & & & \\
\hline $1 \ldots$ & $82 \mathrm{a}-\mathrm{c}$ & 86 a-d & $84 \mathrm{a}-\mathrm{c}$ & $73 \mathrm{bc}$ & $80 \mathrm{~b}-\mathrm{d}$ & $158 \mathrm{a}$ & 150 & 154 & 139 a & 149 a \\
\hline & $85 \mathrm{ab}$ & $93 \mathrm{a}$ & 89 a & $80 \mathrm{~b}$ & $86 \mathrm{ab}$ & $158 \mathrm{a}$ & 150 & 154 & 139 a & $149 \mathrm{a}$ \\
\hline 3..................... & $69 \mathrm{~d}-\mathrm{g}$ & $79 c-e$ & $74 \mathrm{a}-\mathrm{c}$ & $67 \mathrm{~cd}$ & $72 \mathrm{~d}-\mathrm{h}$ & $143 \mathrm{bc}$ & 150 & 147 & $130 \mathrm{a}-\mathrm{c}$ & $141 \mathrm{ab}$ \\
\hline $4 \ldots \ldots \ldots \ldots$ & $70 \mathrm{~d}-\mathrm{g}$ & 83 a-e & $76 \mathrm{a}-\mathrm{c}$ & $68 \mathrm{~cd}$ & $73 \mathrm{~d}-\mathrm{h}$ & $158 \mathrm{a}$ & 150 & 154 & 119 c-e & $142 a b$ \\
\hline $5 \ldots \ldots \ldots \ldots \ldots . .$. & $68 \mathrm{~d}-\mathrm{g}$ & 86 a-d & $77 \mathrm{a}-\mathrm{c}$ & $67 \mathrm{~cd}$ & $74 \mathrm{c}-\mathrm{h}$ & $153 \mathrm{ab}$ & 150 & 152 & 124 b-e & $142 a b$ \\
\hline $6 \ldots \ldots \ldots \ldots . .$. & 69 d-g & 76 de & $73 \mathrm{a}-\mathrm{c}$ & $67 \mathrm{~cd}$ & $71 \mathrm{e}-\mathrm{h}$ & $138 \mathrm{c}$ & 149 & 143 & $125 \mathrm{~b}-\mathrm{e}$ & $137 \mathrm{ab}$ \\
\hline $7 \ldots \ldots \ldots \ldots \ldots . . .$. & $66 \mathrm{e}-\mathrm{g}$ & 86 a-d & $76 \mathrm{a}-\mathrm{c}$ & $67 \mathrm{~cd}$ & $73 \mathrm{~d}-\mathrm{h}$ & $158 \mathrm{a}$ & 150 & 154 & $121 \mathrm{c}-\mathrm{e}$ & $143 a b$ \\
\hline 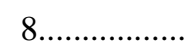 & $70 \mathrm{~d}-\mathrm{g}$ & $88 \mathrm{a}-\mathrm{c}$ & $79 \mathrm{a}-\mathrm{c}$ & $73 \mathrm{bc}$ & $77 \mathrm{c}-\mathrm{f}$ & $143 \mathrm{bc}$ & 150 & 147 & $120 \mathrm{c}-\mathrm{e}$ & $138 a b$ \\
\hline $9 \ldots \ldots \ldots \ldots$ & $86 a b$ & 83 a-e & $84 \mathrm{a}-\mathrm{c}$ & $79 \mathrm{~b}$ & $82 \mathrm{a}-\mathrm{c}$ & $158 \mathrm{a}$ & 150 & 154 & $137 \mathrm{ab}$ & $148 \mathrm{a}$ \\
\hline $10 \ldots \ldots \ldots \ldots . . . . .$. & 79 a-d & $79 \mathrm{c}-\mathrm{e}$ & $79 \mathrm{a}-\mathrm{c}$ & $66 \mathrm{~cd}$ & $75 \mathrm{c}-\mathrm{g}$ & $158 \mathrm{a}$ & 150 & 154 & 127 a-d & $145 a b$ \\
\hline 11 ................... & $63 \mathrm{fg}$ & $79 \mathrm{c}-\mathrm{e}$ & $71 \mathrm{a}-\mathrm{c}$ & $64 \mathrm{~cd}$ & $69 \mathrm{f}-\mathrm{h}$ & $138 \mathrm{c}$ & 150 & 144 & $114 \mathrm{de}$ & $134 \mathrm{~b}$ \\
\hline $12 \ldots \ldots \ldots$ & $61 \mathrm{fg}$ & $85 \mathrm{a}-\mathrm{d}$ & $73 \mathrm{a}-\mathrm{c}$ & $65 \mathrm{~cd}$ & 70 e-h & $143 \mathrm{bc}$ & 150 & 147 & $113 \mathrm{e}$ & $135 \mathrm{~b}$ \\
\hline $13 \ldots \ldots \ldots$ & $72 \mathrm{c}-\mathrm{f}$ & $91 \mathrm{ab}$ & $81 \mathrm{a}-\mathrm{c}$ & $69 \mathrm{~cd}$ & 77 c-f & $143 \mathrm{bc}$ & 149 & 146 & $132 \mathrm{a}-\mathrm{c}$ & $141 \mathrm{ab}$ \\
\hline $14 \ldots \ldots \ldots \ldots$ & $63 \mathrm{fg}$ & $78 \mathrm{c}-\mathrm{e}$ & $70 \mathrm{a}-\mathrm{c}$ & $63 \mathrm{~d}$ & $68 \mathrm{gh}$ & $138 \mathrm{c}$ & 149 & 143 & $116 \mathrm{de}$ & $134 \mathrm{~b}$ \\
\hline $15 \ldots \ldots \ldots \ldots$ & $59 \mathrm{~g}$ & $75 \mathrm{de}$ & $67 \mathrm{bc}$ & $63 \mathrm{~d}$ & $66 \mathrm{~h}$ & $138 \mathrm{c}$ & 147 & 143 & $114 \mathrm{de}$ & $133 \mathrm{~b}$ \\
\hline $16 \ldots \ldots \ldots \ldots$ & $59 \mathrm{~g}$ & $73 \mathrm{e}$ & $66 \mathrm{c}$ & $66 \mathrm{~cd}$ & $66 \mathrm{~h}$ & $138 \mathrm{c}$ & 150 & 144 & $116 \mathrm{de}$ & $135 \mathrm{~b}$ \\
\hline $17 \ldots$ & $62 \mathrm{fg}$ & $81 \mathrm{~b}-\mathrm{e}$ & $71 \mathrm{a}-\mathrm{c}$ & $67 \mathrm{~cd}$ & 70 e-h & $158 \mathrm{a}$ & 150 & 154 & 127 a-d & $145 a b$ \\
\hline $18 \ldots$ & $88 \mathrm{a}$ & $88 \mathrm{a}-\mathrm{c}$ & $88 \mathrm{ab}$ & $90 \mathrm{a}$ & 89 a & $158 \mathrm{a}$ & 150 & 154 & 139 a & $149 \mathrm{a}$ \\
\hline $19 \ldots \ldots \ldots$ & $68 \mathrm{~d}-\mathrm{g}$ & 79 a-e & $74 \mathrm{a}-\mathrm{c}$ & $66 \mathrm{~cd}$ & 71 e-h & $158 \mathrm{a}$ & 150 & 154 & 126 a-e & $145 a b$ \\
\hline $20 \ldots \ldots \ldots$ & $75 \mathrm{~b}-\mathrm{e}$ & $92 \mathrm{ab}$ & $83 \mathrm{a}-\mathrm{c}$ & $69 \mathrm{~cd}$ & 78 b-e & $153 \mathrm{ab}$ & 150 & 152 & $122 \mathrm{c}-\mathrm{e}$ & $142 \mathrm{ab}$ \\
\hline F (Gen.) & $15,54^{*}$ & $6,10^{*}$ & $2,99 *$ & $13,12^{*}$ & $9,27 *$ & $11,43^{*}$ & 1,43 & 1,23 & $10,42^{*}$ & $3,82^{*}$ \\
\hline $\mathrm{F}$ (Anos) & - & - & $52,98^{*}$ & - & - & - & & 0,004 & - & \\
\hline F (Ensaios) & - & - & - & - & $57,85^{*}$ & - & & & - & $117,44^{*}$ \\
\hline$F(G \times A)$ & - & - & $5,03^{*}$ & - & - & - & - & $8,96^{*}$ & - & - \\
\hline$F(G \times E)$ & - & - & - & - & $3,42 *$ & - & - & - & - & $5,85^{*}$ \\
\hline d.m.s. ${ }^{(1)}$ & 12 & 12 & 22 & 10 & 9 & 14 & 4 & 24 & 14 & 13 \\
\hline C.V. (\%) & 6,49 & 5,53 & 6,20 & 5,32 & 6,98 & 3,52 & 0,92 & 2,67 & 4,39 & 3,75 \\
\hline
\end{tabular}

${ }^{(1)}$ Médias seguidas de, pelo menos, uma letra comum não diferem, entre si, pelo teste de Tukey .

*Significativo a $5 \%$. 
Verificaram-se efeitos significativos para genótipos, para ensaios e para a interação genótipos $\mathrm{x}$ ensaios, por meio da análise da variância para o ciclo da emergência ao florescimento, considerando-se em conjunto os três Ensaios I.

Na média desses ensaios, a linhagem 18 (89 dias) apresentou o maior ciclo da emergência ao florescimento, não diferindo apenas das linhagens 2 e 9. As linhagens 15 e 16, com um ciclo da emergência ao florescimento de 66 dias, foram as mais precoces para florescer, diferindo dos genótipos $1,2,8,9,10,13,18$ e 20, com um ciclo de 75 a 89 dias.

A análise da variância em Capão Bonito, em ambos os anos, mostrou efeitos significativos para genótipos, para anos e para a interação genótipos x anos, quando se considerou o ciclo da emergência ao florescimento.

Na média dos ensaios em Capão Bonito, a linhagem 2 (89 dias) apresentou o maior ciclo para florescer, diferindo somente das linhagens 15 e 16 (67 e 66 dias).

Em 1999, em Capão Bonito, a linhagem 18 (88 dias) mostrou o maior ciclo para o florescimento, não diferindo apenas das linhagens 1, 2, 9 e 10, com um ciclo variando de 79 a 86 dias. Em 2000, a linhagem 2 (93 dias) foi a mais tardia para florescer, não diferindo dos genótipos 3, 6, 10, 11, 14, 15, 16 e 17, com ciclos de 73 a 81 dias.

Em Tatuí, em 2000, a linhagem 18 (90 dias) apresentou o maior ciclo para florescer, diferindo dos demais genótipos, com ciclo entre 63 e 80 dias. A análise da variância para a média do número de dias decorridos da emergência à maturação, considerando-se em conjunto os três ensaios, exibiu efeitos significativos para genótipos, para ensaios e para a interação genótipos x ensaios.

$\mathrm{Na}$ média desses três ensaios, as linhagens 1, 2, 9 e 18 apresentaram os maiores ciclos para a maturação, diferindo apenas das linhagens 11, 12, 14, 15 e 16, com ciclo de 133 a 135 dias.

Considerando-se em conjunto os ensaios de Capão Bonito, em 1999 e 2000, a análise da variância revelou efeitos significativos apenas para a interação genótipos $\mathrm{x}$ anos.

Quando avaliados em Capão Bonito, em 1999 e 2000, os genótipos apresentaram um ciclo da emergência à maturação de 143 a 154 dias, porém não diferiram estatisticamente entre si. 
Em 1999, as linhagens 6, 11, 14, 15 e 16 (138 dias) foram as mais precoces, não diferindo das linhagens 3, 8, 12 e 13 (143 dias). No ano seguinte, não houve diferenças estatísticas entre as médias dos genótipos, quando se aplicou o teste de Tukey, a $5 \%$.

Em Tatuí, em 2000, as linhagens 1, 2 e 18, com 139 dias da emergência à maturação foram as mais tardias, não diferindo das linhagens $3,9,10,13,17$ e 19 .

Dos genótipos avaliados no Ensaio de Linhagens Diaplóides de Trigo I, quando considerados em conjunto os três ensaios, destacaram-se as linhagens 15 e 16, apresentando, ao mesmo tempo, os ciclos mais precoces para florescer e para maturar.

A interação genótipos $\mathrm{x}$ ensaios e genótipos $\mathrm{x}$ anos para produção de grãos, altura da planta e ciclos da emergência ao florescimento e da emergência à maturação, obtidas no Ensaio de Linhagens Diaplóides de Trigo I, concordam com resultados obtidos por Camargo et al. (1989), avaliando o comportamento de linhagens originárias de trigos de inverno e de primavera, e Camargo et al. (1991a), pesquisando genótipos oriundos de populações híbridas introduzidas de Oregon, em diferentes regiões paulistas.

As porcentagens médias de acamamento dos genótipos avaliados no Ensaio de Linhagens Diaplóides de Trigo I encontram-se na Tabela 7. Os genótipos 1, 2, 10, 18 e 20 mostraram-se resistentes ao acamamento, considerando-se em conjunto a média dos quatro ensaios. Destacaram-se, também, pela baixa presença de plantas acamadas, os genótipos 9, 13 e 19 (1\%), os quais poderiam ser indicados para cultivo em condição de irrigação por aspersão.

Nos ensaios de Capão Bonito e Tatuí, houve uma tendência de menor acamamento em 2000, quando comparado ao ano anterior, isso poderia estar relacionado ao menor desenvolvimento vegetativo resultante da maior escassez de água em 2000, na Estação Experimental de Capão Bonito, e às geadas, prejudicando o desenvolvimento dos genótipos em Tatuí.

A correlação entre altura das plantas e a porcentagem de acamamento $(r=0,19)$ não foi significativa a 5\%, quando se consideraram as médias obtidas nos quatro Ensaios de Linhagens Diaplóides de Trigo I, de Capão Bonito e Tatuí, em ambos os anos, demonstrando não haver tendência de os genótipos mais altos apresentarem as maiores 
Tabela 7. Porcentagem de acamamento dos genótipos avaliados no Ensaio de Linhagens Diaplóides de Trigo I, nas Estações Experimentais de Agronomia de Capão Bonito e Tatuí em 1999 e 2000.

\begin{tabular}{|c|c|c|c|c|c|c|c|}
\hline \multirow{3}{*}{ Genótipos } & \multicolumn{7}{|c|}{ Acamamento } \\
\hline & \multicolumn{3}{|c|}{ Capão Bonito } & \multicolumn{3}{|c|}{ Tatuí } & \multirow{2}{*}{$\begin{array}{l}\text { Média } \\
\text { geral }\end{array}$} \\
\hline & 1999 & 2000 & Média & 1999 & 2000 & Média & \\
\hline & & & & $\%$ & & & - \\
\hline $1 \ldots \ldots \ldots \ldots$ & 0 & 0 & 0 & 0 & 0 & 0 & 0 \\
\hline 2 . & 0 & 0 & 0 & 0 & 0 & 0 & 0 \\
\hline $3 \ldots \ldots \ldots \ldots$ & 20 & 0 & 10 & 5 & 0 & 3 & 6 \\
\hline $4 \ldots \ldots \ldots \ldots$ & 0 & 0 & 0 & 15 & 0 & 8 & 4 \\
\hline $5 \ldots \ldots \ldots \ldots . . . . . .$. & 5 & 5 & 5 & 5 & 5 & 5 & 5 \\
\hline $6 \ldots \ldots \ldots \ldots . . .$. & 20 & 0 & 10 & 5 & 5 & 5 & 8 \\
\hline $7 \ldots \ldots$ & 0 & 5 & 3 & 10 & 10 & 10 & 6 \\
\hline 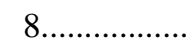 & 25 & 5 & 15 & 30 & 20 & 25 & 20 \\
\hline $9 \ldots \ldots$ & 0 & 0 & 0 & 0 & 5 & 3 & 1 \\
\hline $10 \ldots \ldots \ldots \ldots . . .$. & 0 & 0 & 0 & 0 & 0 & 0 & 0 \\
\hline $11 \ldots \ldots \ldots \ldots$ & 30 & 0 & 15 & 5 & 5 & 5 & 10 \\
\hline $12 \ldots$ & 20 & 10 & 15 & 5 & 5 & 5 & 10 \\
\hline $13 \ldots \ldots \ldots . . . . . . .$. & 0 & 0 & 0 & 0 & 5 & 3 & 1 \\
\hline $14 \ldots \ldots \ldots \ldots$ & 25 & 10 & 18 & 15 & 10 & 13 & 15 \\
\hline $15 \ldots \ldots$ & 35 & 0 & 18 & 20 & 15 & 18 & 18 \\
\hline $16 \ldots \ldots \ldots \ldots$ & 35 & 5 & 20 & 5 & 15 & 10 & 15 \\
\hline $17 \ldots \ldots$ & 0 & 5 & 3 & 25 & 0 & 13 & 8 \\
\hline $18 \ldots \ldots \ldots$ & 0 & 0 & 0 & 0 & 0 & 0 & 0 \\
\hline $19 \ldots \ldots \ldots$ & 0 & 5 & 3 & 0 & 0 & 0 & 1 \\
\hline $20 \ldots \ldots \ldots \ldots . . . . . . . .$. & 0 & 0 & 0 & 0 & 0 & 0 & 0 \\
\hline
\end{tabular}


maiores porcentagens de acamamento. Essas observações contrariam as de Souza (1998), ao sugerir que a maior resistência ao acamamento poderia estar associada à baixa altura da planta. Uma das razões para essa contradição, possivelmente, fosse a baixa altura apresentada por todos os genótipos avaliados.

Nas Tabelas 8, 9 e 10, encontram-se, respectivamente, os graus médios de infecção de ferrugem-da-folha, mancha-da-folha e oídio, dos genótipos de trigo do Ensaio de Linhagens Diaplóides de Trigo I, de Capão Bonito e Tatuí em 1999 e 2000.

Em relação à ferrugem-da-folha, destacaram-se, em Capão Bonito, os genótipos 2, 9 e 18, apresentando-se como resistentes nos ensaios considerados. Com exceção da linhagem 10, que exibiu suscetibilidade (38S) em 1999, os demais genótipos foram moderadamente resistentes em Capão Bonito, por exibirem um grau máximo de infecção entre 6 e $25 \%$, em, pelo menos, um dos anos.

Em Tatuí, todas as linhagens, com uma porcentagem máxima de área foliar infectada entre 6 e 24\% mostraram-se moderadamente resistentes ao agente causal da ferrugem-da-folha. A 8, com um grau máximo de infecção de 55\%, mostrou-se altamente suscetível, e os genótipos 10, 13, 14, 17 e 20, com um grau máximo de infecção variando de 30 a 43\%, suscetíveis.

Nos ensaios de Capão Bonito, em 1999, e Tatuí, em 1999 e 2000, quando se considerou a avaliação da mancha-da-folha nas folhas superiores, verificou-se que os genótipos 2, 4 e 18 foram moderadamente resistentes, com um grau máximo de infecção entre 20 e $25 \%$. Os demais genótipos foram considerados suscetíveis pelo grau de infecção entre 30 e 50\%, em, pelo menos, um ensaio, e as linhagens 6, 8, 11, 13, 14 e 17, com grau máximo de infecção entre 60 e 80\%, altamente suscetíveis (Tabela 9).

A porcentagem de ocorrência de infecção de mancha-da-folha na folha bandeira, em 2000, no ensaio de Capão Bonito, mostrou valores bem menores, quando comparados aos obtidos nas folhas superiores em 1999, o que já era esperado, uma vez que a principal fonte de contaminação está presente nos restos vegetais depositados no solo (Mehta, 1978 e Vechiato et al., 1987).

Nos anos considerados, sem condições favoráveis ao desenvolvimento de oídio, houve baixa incidência da moléstia. 
Tabela 8. Porcentagem de área foliar infectada pelo agente causal da ferrugem-da-folha ${ }^{(1)}$ dos genótipos avaliados no Ensaio de Linhagens Diaplóides de Trigo I, nas Estações Experimentais de Agronomia de Capão Bonito e Tatuí em 1999 e 2000.

\begin{tabular}{|c|c|c|c|c|}
\hline \multirow{3}{*}{ Genótipos } & \multicolumn{4}{|c|}{ Ferrugem-da-folha } \\
\hline & \multicolumn{2}{|c|}{ Capão Bonito } & \multicolumn{2}{|c|}{ Tatuí } \\
\hline & $1999^{(2)}$ & $2000^{(3)}$ & $1999^{(2)}$ & $2000^{(2)}$ \\
\hline & & & & 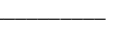 \\
\hline $1 \ldots \ldots \ldots \ldots \ldots$ & $9 \mathrm{~S}$ & $9 \mathrm{~S}$ & $5 \mathrm{~S}$ & $10 \mathrm{~S}$ \\
\hline $2 \ldots \ldots \ldots \ldots \ldots$ & $5 \mathrm{~S}$ & $5 \mathrm{~S}$ & $6 \mathrm{~S}$ & $9 \mathrm{~S}$ \\
\hline 3...................... & $10 \mathrm{~S}$ & $4 \mathrm{~S}$ & $10 \mathrm{~S}$ & $9 \mathrm{~S}$ \\
\hline $4 \ldots \ldots \ldots \ldots \ldots$ & $6 \mathrm{~S}$ & $6 S$ & 9S & $14 \mathrm{~S}$ \\
\hline $5 \ldots \ldots \ldots \ldots \ldots$ & $4 \mathrm{~S}$ & $6 \mathrm{~S}$ & $8 \mathrm{~S}$ & $18 \mathrm{~S}$ \\
\hline $6 \ldots \ldots \ldots \ldots \ldots \ldots$ & $16 \mathrm{~S}$ & $18 \mathrm{~S}$ & $24 S$ & $10 \mathrm{~S}$ \\
\hline 7 ....................... & $7 \mathrm{~S}$ & $5 \mathrm{~S}$ & $5 \mathrm{~S}$ & $13 \mathrm{~S}$ \\
\hline 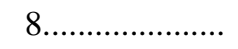 & $25 \mathrm{~S}$ & $16 \mathrm{~S}$ & $55 \mathrm{~S}$ & $16 \mathrm{~S}$ \\
\hline $9 \ldots \ldots \ldots \ldots \ldots \ldots \ldots$ & $1 \mathrm{~S}$ & $2 \mathrm{~S}$ & $4 \mathrm{~S}$ & $9 \mathrm{~S}$ \\
\hline $10 \ldots \ldots \ldots \ldots$ & $38 \mathrm{~S}$ & $8 \mathrm{~S}$ & $43 \mathrm{~S}$ & $11 \mathrm{~S}$ \\
\hline $11 \ldots \ldots \ldots \ldots \ldots$ & $14 S$ & $13 \mathrm{~S}$ & $18 \mathrm{~S}$ & $13 \mathrm{~S}$ \\
\hline $12 \ldots \ldots \ldots \ldots \ldots \ldots$ & $10 \mathrm{~S}$ & $10 \mathrm{~S}$ & $20 \mathrm{~S}$ & $13 \mathrm{~S}$ \\
\hline $13 \ldots \ldots \ldots \ldots \ldots$ & $20 \mathrm{~S}$ & $16 \mathrm{~S}$ & $33 \mathrm{~S}$ & $25 \mathrm{~S}$ \\
\hline $14 \ldots \ldots \ldots \ldots \ldots \ldots$ & $23 \mathrm{~S}$ & $15 \mathrm{~S}$ & $40 \mathrm{~S}$ & $21 \mathrm{~S}$ \\
\hline $15 \ldots \ldots \ldots \ldots \ldots$ & $5 \mathrm{~S}$ & $8 \mathrm{~S}$ & $6 \mathrm{~S}$ & $11 \mathrm{~S}$ \\
\hline $16 \ldots \ldots \ldots \ldots \ldots$ & $12 \mathrm{~S}$ & $6 \mathrm{~S}$ & $10 \mathrm{~S}$ & $18 \mathrm{~S}$ \\
\hline $17 \ldots \ldots \ldots \ldots \ldots \ldots$ & $16 \mathrm{~S}$ & $15 \mathrm{~S}$ & $33 \mathrm{~S}$ & $18 \mathrm{~S}$ \\
\hline 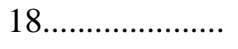 & $\mathrm{tS}$ & 0 & $3 \mathrm{~S}$ & $6 \mathrm{~S}$ \\
\hline $19 \ldots \ldots \ldots \ldots \ldots \ldots$ & $9 \mathrm{~S}$ & $16 \mathrm{~S}$ & $16 \mathrm{~S}$ & $19 \mathrm{~S}$ \\
\hline $20 \ldots \ldots \ldots \ldots \ldots \ldots \ldots$ & 9S & $8 \mathrm{~S}$ & $30 \mathrm{~S}$ & $13 \mathrm{~S}$ \\
\hline
\end{tabular}

${ }^{(1)}$ Avaliação de ferrugem-da-folha segundo Schramm et. al. (1974): $0=$ imune; 1 a 5\% de área infectada $=$ resistente; 6 a $25 \%=$ moderadamente resistente; 26 a $50 \%=$ suscetível, e 51 a $99 \%$ = altamente suscetível; $\mathrm{t}=$ traço (apenas algumas pústulas); $\mathrm{S}=$ reação de suscetibilidade; $\mathrm{MS}$ = reação de moderada suscetibilidade.

(2) Avaliação realizadas nas folhas superiores.

(3) Avaliação realizada apenas na folha bandeira. 
Tabela 9. Porcentagem de área foliar infectada pelo agente causal da mancha-da-folha ${ }^{(1)}$ dos genótipos avaliados no Ensaio de Linhagens Diaplóides de Trigo I, nas Estações Experimentais de Agronomia de Capão Bonito e Tatuí em 1999 e 2000.

\begin{tabular}{|c|c|c|c|c|}
\hline \multirow{3}{*}{ Genótipos } & \multicolumn{4}{|c|}{ Mancha-da-folha } \\
\hline & \multicolumn{2}{|c|}{ Capão Bonito } & \multicolumn{2}{|c|}{ Tatuí } \\
\hline & $1999^{(2)}$ & $2000^{(3)}$ & $1999^{(2)}$ & $2000^{(2)}$ \\
\hline $1 \ldots \ldots \ldots \ldots \ldots$ & 20 & 3 & 20 & 30 \\
\hline $2 \ldots \ldots \ldots \ldots \ldots$ & 23 & 3 & 20 & 20 \\
\hline $3 \ldots \ldots \ldots \ldots \ldots$ & 23 & 5 & 23 & 30 \\
\hline $4 \ldots$ & 23 & 3 & 25 & 20 \\
\hline 5 & 25 & 4 & 25 & 40 \\
\hline $6 \ldots \ldots \ldots \ldots \ldots$ & 25 & 14 & 30 & 70 \\
\hline $7 \ldots \ldots \ldots$ & 25 & 1 & 23 & 40 \\
\hline 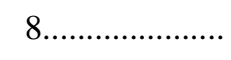 & 25 & 4 & 35 & 80 \\
\hline 9 & 20 & 2 & 20 & 30 \\
\hline 10 & 35 & 3 & 38 & 40 \\
\hline $11 \ldots \ldots \ldots$ & 25 & 2 & 28 & 70 \\
\hline $12 \ldots \ldots \ldots \ldots \ldots \ldots$ & 23 & 2 & 23 & 30 \\
\hline $13 \ldots \ldots \ldots$ & 38 & 3 & 35 & 60 \\
\hline $14 \ldots \ldots \ldots \ldots \ldots$ & 28 & 6 & 33 & 60 \\
\hline $15 \ldots \ldots \ldots \ldots \ldots$ & 25 & 4 & 23 & 50 \\
\hline $16 \ldots \ldots \ldots \ldots \ldots$ & 20 & 3 & 23 & 30 \\
\hline $17 \ldots \ldots \ldots$ & 33 & 5 & 35 & 70 \\
\hline $18 \ldots \ldots \ldots \ldots$ & 20 & 1 & 20 & 10 \\
\hline $19 \ldots \ldots \ldots \ldots$ & 23 & 10 & 25 & 30 \\
\hline $20 \ldots \ldots \ldots \ldots$ & 30 & 1 & 23 & 40 \\
\hline
\end{tabular}

${ }^{(1)}$ Avaliação de mancha-da-folha segundo Mehta (1978): 0 = imune; 1 a 5\% de área infectada $=$ resistente 6 a $25 \%=$ moderadamente resistente; 26 a $50 \%=$ suscetível, e 51 a $99 \%$ = altamente suscetível.

(2) Avaliação realizadas nas folhas superiores.

(3) Avaliação realizada apenas na folha bandeira. 
Tabela 10. Porcentagem de área foliar infectada pelo agente causal do oídio $^{(1)}$ dos genótipos avaliados no Ensaio de Linhagens Diaplóides de Trigo I, nas Estações Experimentais de Agronomia de Capão Bonito e Tatuí em 1999 e 2000.

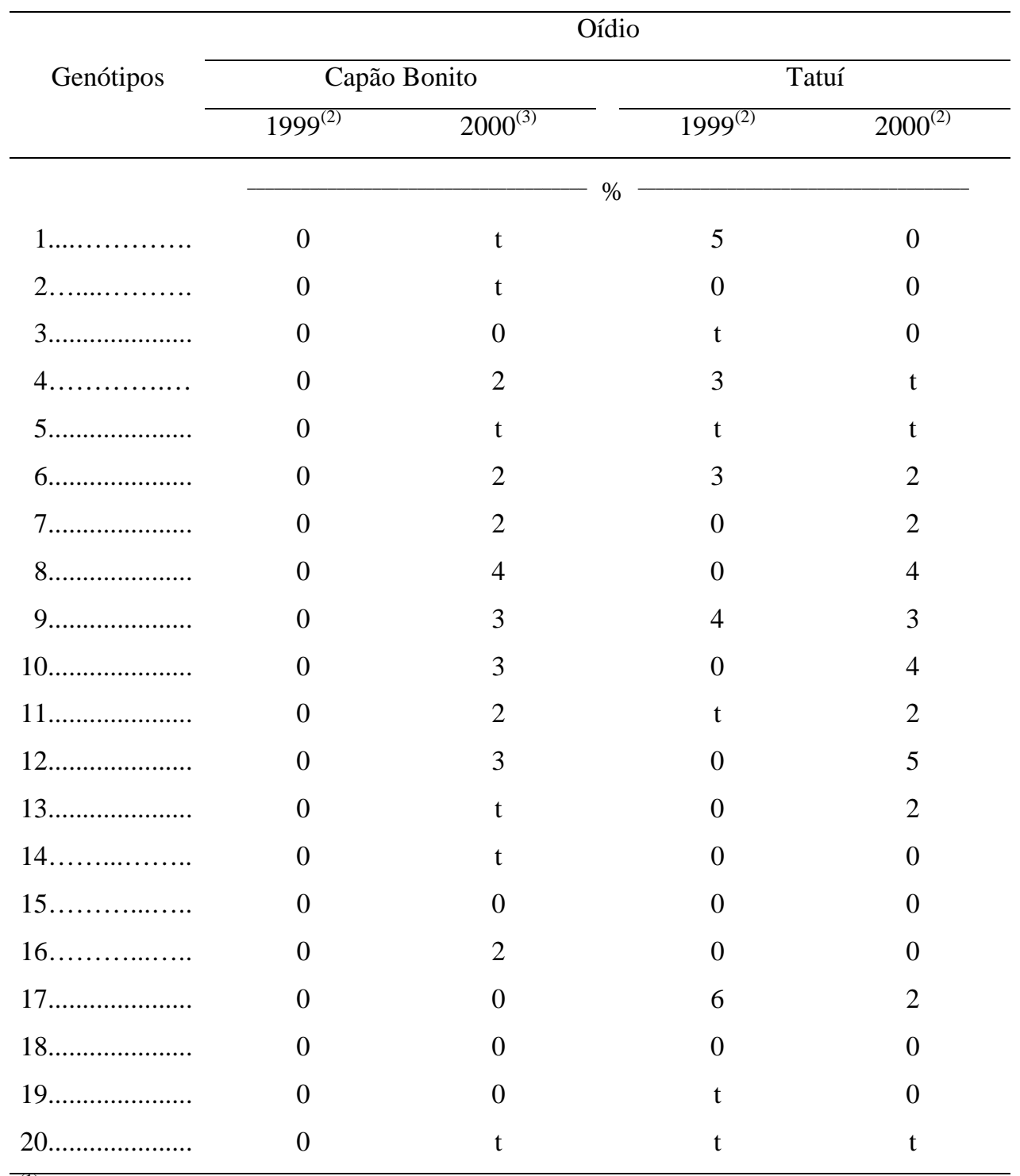

${ }^{(1)}$ Avaliação de oídio segundo Mehta (1978): 0 = imune; 1 a 5\% de área infectada = resistente; 6 a $25 \%=$ moderadamente resistente; 26 a $50 \%=$ suscetível, e 51 a $99 \%=$ altamente suscetível.

${ }^{(2)}$ Avaliação realizadas nas folhas superiores.

(3) Avaliação realizada apenas na folha bandeira. 
Observa-se, na Tabela 10, que as linhagens 15 e 18 foram imunes ao oídio. Os demais genótipos, com exceção da linhagem 17, com moderada resistência (6\%) em, pelo menos, um dos ensaios, foram considerados resistentes.

As linhagens 2, 4 e 18 destacaram-se por apresentar, ao mesmo tempo, moderada resistência aos agentes causais da ferrugem-da-folha e da mancha-da-folha, e imunidade ou resistência ao agente causal do oídio, e poderiam, portanto, ser aproveitadas em programas de melhoramento visando à resistência a essas moléstias.

Nas Tabelas 11, 12, 13, 14 e 15 encontram-se os dados médios referentes ao comprimento da espiga, ao número de espiguetas por espiga e de grãos por espiga e por espigueta e massa de cem grãos dos genótipos de trigo do Ensaio de Linhagens Diaplóides de Trigo I, em Capão Bonito e Tatuí, em 1999 e 2000.

A análise da variância dos dados médios de comprimento da espiga, considerando em conjunto os quatro ensaios, mostrou efeitos significativos para genótipos, para ensaios e para a interação genótipos $\mathrm{x}$ ensaios, indicando que os genótipos apresentaram comportamento diferencial nos diferentes ambientes.

A linhagem $2(9,1 \mathrm{~cm})$ exibiu as espigas mais compridas, diferindo somente, porém, dos genótipos $6,10,11,12,16,17,19$ e 20, cujo comprimento da espiga variou de 7,3 a 7,9 cm, quando consideradas as médias dos quatro ensaios.

A análise conjunta dos ensaios de Capão Bonito, em 1999 e 2000, apresentando efeitos significativos para genótipos, para anos e para a interação genótipos $\mathrm{x}$ anos, indicou que os genótipos tiveram comportamento diferencial em relação aos anos. Não se detectaram diferenças significativas entre os genótipos pelo teste de Tukey a 5\%, na média dos dois anos.

Comparando-se as médias de comprimento da espiga, considerando-se o ensaio instalado em Capão Bonito, em 1999, destacou-se a linhagem 18 (9,0 cm), diferindo, porém, apenas das linhagens 6, 9, 10 e 17, com um comprimento da espiga de 7,4 a 7,7 cm. Em 2000, a linhagem 18 (7,9 cm), também exibiu as espigas mais compridas, não diferindo somente das linhagens 2 e $5(7,1 \mathrm{~cm}), 8(7,3 \mathrm{~cm})$ e $9(6,9 \mathrm{~cm})$. 
Tabela 11. Comprimento médio da espiga, dos genótipos avaliados no Ensaio de Linhagens Diaplóides de Trigo I, nas Estações Experimentais de Agronomia de Capão Bonito e Tatuí em 1999 e 2000.

\begin{tabular}{|c|c|c|c|c|c|c|c|}
\hline \multirow{3}{*}{ Genótipos } & \multicolumn{7}{|c|}{ Comprimento da espiga } \\
\hline & \multicolumn{3}{|c|}{ Capão Bonito } & \multicolumn{3}{|c|}{ Tatuí } & \multirow{2}{*}{$\begin{array}{c}\text { Média } \\
\text { geral }\end{array}$} \\
\hline & 1999 & 2000 & Média & 1999 & 2000 & Média & \\
\hline & & & & $\mathrm{cm}$ & & & \\
\hline $1 \ldots \ldots \ldots \ldots$ & 8,0 a-d & $6,2 \mathrm{~b}-\mathrm{f}$ & 7,1 & $10,5 \mathrm{ab}$ & $9,1 \mathrm{a}-\mathrm{c}$ & $9,8 \mathrm{ab}$ & 8,4 a-e \\
\hline $2 \ldots \ldots \ldots \ldots$ & $8,9 a b$ & $7,1 \mathrm{ab}$ & 8,0 & $10,8 \mathrm{a}$ & $9,7 \mathrm{a}$ & $10,3 \mathrm{a}$ & $9,1 \mathrm{a}$ \\
\hline $3 \ldots \ldots \ldots \ldots \ldots . . .$. & 7,8 a-d & 6,4 b-e & 7,1 & 9,9 a-e & 8,6 a-e & 9,3 b-d & 8,2 a-e \\
\hline $4 \ldots$ & 7,9 a-d & $6,5 b-d$ & 7,2 & 10,0 a-d & $9,1 \mathrm{a}-\mathrm{c}$ & $9,5 \mathrm{a}-\mathrm{c}$ & 8,4 a-e \\
\hline $5 \ldots .$. & $8,7 \mathrm{a}-\mathrm{c}$ & $7,1 \mathrm{ab}$ & 7,9 & $9,5 b-f$ & $9,4 \mathrm{ab}$ & $9,5 \mathrm{a}-\mathrm{c}$ & $8,7 \mathrm{a}-\mathrm{c}$ \\
\hline $6 \ldots \ldots \ldots \ldots . . .$. & $7,4 \mathrm{~d}$ & $5,6 \mathrm{~d}-\mathrm{f}$ & 6,5 & $8,7 \mathrm{fg}$ & $8,0 \mathrm{c}-\mathrm{f}$ & $8,3 \mathrm{~d}-\mathrm{f}$ & $7,4 \mathrm{de}$ \\
\hline $7 \ldots \ldots \ldots . . . . .$. & 8,3 a-d & $6,5 \mathrm{~b}-\mathrm{d}$ & 7,4 & $9,1 \mathrm{~d}-\mathrm{g}$ & 8,9 a-d & 9,0 b-e & 8,2 a-e \\
\hline $8 \ldots \ldots \ldots \ldots . . . .$. & $8,5 \mathrm{a}-\mathrm{d}$ & $7,3 \mathrm{ab}$ & 7,9 & 9,6 b-f & $8,5 \mathrm{a}-\mathrm{f}$ & 9,1 b-e & 8,5 a-d \\
\hline 9 & $7,6 \mathrm{~cd}$ & $6,9 \mathrm{a}-\mathrm{c}$ & 7,3 & 9,4 d-g & 8,7 a-e & 9,1 b-e & $8,2 \mathrm{a}-\mathrm{e}$ \\
\hline $10 \ldots \ldots \ldots \ldots \ldots$ & $7,5 \mathrm{~cd}$ & $5,5 \mathrm{~d}-\mathrm{f}$ & 6,5 & $8,9 \mathrm{e}-\mathrm{g}$ & 7,4 ef & 8,1 ef & $7,3 \mathrm{e}$ \\
\hline $11 \ldots \ldots \ldots \ldots \ldots$ & 7,8 a-d & $5,2 \mathrm{f}$ & 6,5 & 10,0 a-d & 8,6 a-e & 9,3 b-d & 7,9 b-e \\
\hline $12 \ldots \ldots \ldots \ldots . . .$. & 7,9 a-d & $5,3 \mathrm{ef}$ & 6,6 & 9,6 b-f & $8,5 \mathrm{a}-\mathrm{f}$ & 9,1 b-e & $7,8 \mathrm{c-e}$ \\
\hline $13 \ldots \ldots \ldots \ldots$ & $8,9 \mathrm{ab}$ & $5,5 \mathrm{~d}-\mathrm{f}$ & 7,2 & 10,0 a-d & $9,1 \mathrm{a}-\mathrm{c}$ & $9,5 \mathrm{a}-\mathrm{c}$ & 8,4 a-e \\
\hline $14 \ldots \ldots \ldots \ldots \ldots$ & $8,7 \mathrm{a}-\mathrm{c}$ & $6,3 \mathrm{~b}-\mathrm{f}$ & 7,5 & $10,2 \mathrm{a}-\mathrm{c}$ & 8,7 a-e & $9,5 \mathrm{a}-\mathrm{c}$ & $8,5 \mathrm{a}-\mathrm{d}$ \\
\hline $15 \ldots \ldots \ldots \ldots$ & $8,3 \mathrm{a}-\mathrm{d}$ & $5,8 \mathrm{c}-\mathrm{f}$ & 7,0 & $9,6 b-f$ & $8,3 \mathrm{~b}-\mathrm{f}$ & $9,0 \mathrm{~b}-\mathrm{e}$ & 8,0 a-e \\
\hline $16 \ldots \ldots \ldots \ldots$ & 8,6 a-d & $5,6 \mathrm{~d}-\mathrm{f}$ & 7,1 & 9,5 b-f & $7,6 \mathrm{~d}-\mathrm{f}$ & $8,5 \mathrm{c}-\mathrm{f}$ & $7,8 \mathrm{c-e}$ \\
\hline $17 \ldots \ldots \ldots \ldots . . . .$. & 7,7 b-d & $5,9 \mathrm{c}-\mathrm{f}$ & 6,8 & $8,4 \mathrm{~g}$ & $7,2 \mathrm{f}$ & $7,8 \mathrm{f}$ & $7,3 \mathrm{e}$ \\
\hline 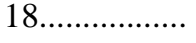 & $9,0 \mathrm{a}$ & $7,9 \mathrm{a}$ & 8,4 & 10,0 a-d & 9,0 a-c & $9,5 \mathrm{a}-\mathrm{c}$ & $9,0 a b$ \\
\hline 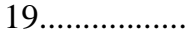 & 7,9 a-d & $5,6 \mathrm{~d}-\mathrm{f}$ & 6,8 & $8,6 \mathrm{fg}$ & 7,6 d-f & 8,1 ef & $7,4 \mathrm{de}$ \\
\hline $20 \ldots \ldots \ldots \ldots \ldots . . .$. & $8,1 \mathrm{a}-\mathrm{d}$ & $5,4 \mathrm{~d}-\mathrm{f}$ & 6,7 & $9,2 \mathrm{~d}-\mathrm{g}$ & $7,8 \mathrm{c}-\mathrm{f}$ & $8,5 \mathrm{c}-\mathrm{f}$ & 7,6 c-e \\
\hline F (Gen.) & $4,08^{*}$ & $12,05^{*}$ & $2,49 *$ & $9,62 *$ & $6,48^{*}$ & $8,88^{*}$ & $5,59 *$ \\
\hline F (Anos) & - & - & $164,17 *$ & - & - & $133,63 *$ & - \\
\hline F (Ensaios) & - & - & - & - & - & - & $199,56^{*}$ \\
\hline $\mathrm{F}(\mathrm{G} \times \mathrm{A})$ & - & - & $3,31 *$ & - & - & 1,51 & - \\
\hline$F(G \times E)$ & - & - & - & - & - & - & $3,04 *$ \\
\hline d.m.s. ${ }^{(1)}$ & 1,29 & 1,17 & 2,00 & 1,08 & 1,43 & 1,22 & 1,17 \\
\hline C.V. (\%) & 6,03 & 7,20 & 7,53 & 4,28 & 6,41 & 5,39 & 6,35 \\
\hline
\end{tabular}

${ }^{(1)}$ Médias seguidas de, pelo menos, uma letra comum não diferem, entre si, pelo teste de Tukey.

* Significativo a $5 \%$. 
Tabela 12. Número de espiguetas por espiga dos genótipos avaliados no Ensaio de Linhagens Diaplóides de Trigo I, nas Estações Experimentais de Agronomia de Capão Bonito e Tatuí em 1999 e 2000.

\begin{tabular}{|c|c|c|c|c|c|c|c|}
\hline \multirow{3}{*}{ Genótipos } & \multicolumn{7}{|c|}{ Número de espiguetas por espiga } \\
\hline & \multicolumn{3}{|c|}{ Capão Bonito } & \multicolumn{3}{|c|}{ Tatuí } & \multirow{2}{*}{$\begin{array}{c}\text { Média } \\
\text { geral }\end{array}$} \\
\hline & 1999 & 2000 & Média & 1999 & 2000 & Média & \\
\hline & & & & $-\mathrm{n}^{\mathrm{o}}-$ & & & \\
\hline $1 \ldots \ldots \ldots \ldots$ & 17,2 a-d & $12,3 \mathrm{c}-\mathrm{e}$ & 14,7 a-e & 21,9 a-c & 19,2 a-d & $20,5 \mathrm{a}-\mathrm{c}$ & 17,6 b-e \\
\hline $2 \ldots \ldots \ldots \ldots$ & $19,0 \mathrm{ab}$ & $16,0 \mathrm{ab}$ & $17,5 \mathrm{ab}$ & 21,7 a-d & 19,6 a-c & $20,6 \mathrm{a}-\mathrm{c}$ & $19,1 \mathrm{a}-\mathrm{c}$ \\
\hline ......... & $15,6 \mathrm{c}-\mathrm{e}$ & $13,2 \mathrm{bc}$ & 14,4 b-e & 20,7 b-e & 18,7 a-e & 19,7 a-d & $17,0 \mathrm{~b}-\mathrm{e}$ \\
\hline $4 \ldots$ & $14,6 \mathrm{c}-\mathrm{e}$ & $11,7 \mathrm{c}-\mathrm{g}$ & $13,2 \mathrm{c}-\mathrm{e}$ & $19,3 \mathrm{e}-\mathrm{h}$ & 17,4 b-e & $18,3 \mathrm{~cd}$ & $15,7 \mathrm{~d}-\mathrm{h}$ \\
\hline $5 \ldots$. & $14,2 \mathrm{de}$ & $12,4 \mathrm{~cd}$ & $13,3 \mathrm{c}-\mathrm{e}$ & $18,0 \mathrm{gh}$ & 18,4 a-e & $18,2 \mathrm{~cd}$ & $15,7 \mathrm{~d}-\mathrm{h}$ \\
\hline $6 \ldots \ldots \ldots \ldots . . .$. & $15,8 \mathrm{c}-\mathrm{e}$ & $12,3 \mathrm{c}-\mathrm{e}$ & $14,1 \mathrm{~b}-\mathrm{e}$ & $19,9 \mathrm{c}-\mathrm{g}$ & 18,3 a-e & $19,1 \mathrm{~b}-\mathrm{d}$ & $16,6 \mathrm{~d}-\mathrm{g}$ \\
\hline $7 \ldots \ldots \ldots \ldots . . . .$. & $15,8 \mathrm{c}-\mathrm{e}$ & $13,0 \mathrm{c}$ & 14,4 b-e & 20,2 b-g & 18,4 a-e & $19,3 \mathrm{a}-\mathrm{d}$ & $16,8 \mathrm{c}-\mathrm{e}$ \\
\hline $8 \ldots \ldots \ldots \ldots . . . .$. & $19,7 \mathrm{a}$ & $17,1 \mathrm{a}$ & $18,4 \mathrm{a}$ & $23,4 \mathrm{a}$ & $20,5 \mathrm{a}$ & $22,0 \mathrm{a}$ & $20,2 \mathrm{a}$ \\
\hline 9 & $17,4 \mathrm{a}-\mathrm{c}$ & $17,1 \mathrm{a}$ & $17,3 \mathrm{ab}$ & $22,4 \mathrm{ab}$ & $20,0 \mathrm{ab}$ & $21,2 \mathrm{ab}$ & $19,2 \mathrm{ab}$ \\
\hline $10 \ldots \ldots \ldots \ldots . . . .$. & 16,8 a-e & $11,6 \mathrm{c}-\mathrm{g}$ & 14,2 b-e & $18,4 \mathrm{f}-\mathrm{h}$ & $16,9 \mathrm{c}-\mathrm{e}$ & $17,7 \mathrm{de}$ & $15,9 \mathrm{~d}-\mathrm{h}$ \\
\hline $11 \ldots \ldots \ldots \ldots \ldots$ & 13,9 e & $9,0 \mathrm{fg}$ & $11,4 \mathrm{e}$ & $18,4 \mathrm{f}-\mathrm{h}$ & $16,4 \mathrm{de}$ & $17,4 \mathrm{de}$ & $14,4 \mathrm{f}-\mathrm{h}$ \\
\hline $12 \ldots \ldots \ldots \ldots . . .$. & $14,0 \mathrm{e}$ & $8,9 \mathrm{~g}$ & $11,5 \mathrm{e}$ & $18,1 \mathrm{f}-\mathrm{h}$ & $16,2 \mathrm{ef}$ & $17,1 \mathrm{de}$ & $14,3 \mathrm{gh}$ \\
\hline$\ldots \ldots \ldots . .$. & $14,5 \mathrm{c}-\mathrm{e}$ & $10,0 \mathrm{~d}-\mathrm{g}$ & $12,3 \mathrm{de}$ & 19,4 e-h & 17,9 a-e & 18,7 b-d & $15,5 \mathrm{e}-\mathrm{h}$ \\
\hline $14 \ldots \ldots \ldots \ldots$ & $14,3 \mathrm{de}$ & $11,6 \mathrm{c}-\mathrm{g}$ & $13,0 \mathrm{c}-\mathrm{e}$ & $19,2 \mathrm{e}-\mathrm{h}$ & 17,2 b-e & $18,2 \mathrm{~cd}$ & $15,6 \mathrm{e}-\mathrm{h}$ \\
\hline $15 \ldots \ldots \ldots \ldots$ & $16,1 \mathrm{~b}-\mathrm{e}$ & $12,0 \mathrm{c}-\mathrm{e}$ & $14,0 \mathrm{~b}-\mathrm{e}$ & $20,0 \mathrm{c}-\mathrm{g}$ & 17,5 b-e & 18,7 b-d & $16,4 \mathrm{~d}-\mathrm{g}$ \\
\hline $16 \ldots \ldots \ldots \ldots$ & $13,9 \mathrm{e}$ & $9,5 \mathrm{e}-\mathrm{g}$ & $11,7 \mathrm{de}$ & $17,5 \mathrm{~h}$ & $13,4 \mathrm{f}$ & $15,4 \mathrm{e}$ & $13,6 \mathrm{~h}$ \\
\hline $17 \ldots \ldots \ldots \ldots . . .$. & $17,1 \mathrm{a}-\mathrm{d}$ & $13,5 \mathrm{bc}$ & $15,3 \mathrm{a}-\mathrm{d}$ & $20,2 \mathrm{~b}-\mathrm{g}$ & 17,8 a-e & 19,0 b-d & $17,1 \mathrm{~b}-\mathrm{e}$ \\
\hline $18 \ldots \ldots \ldots \ldots . . .$. & $17,5 \mathrm{a}-\mathrm{c}$ & $16,0 \mathrm{ab}$ & $16,7 \mathrm{a}-\mathrm{c}$ & 21,4 a-e & 17,3 b-e & 19,3 a-d & 18,0 a-d \\
\hline $19 \ldots \ldots \ldots$ & 16,6 b-e & $13,0 \mathrm{c}$ & 14,8 a-e & $19,5 \mathrm{~d}-\mathrm{h}$ & 17,8 a-e & 18,7 b-d & $16,7 \mathrm{~d}-\mathrm{f}$ \\
\hline $20 \ldots \ldots \ldots \ldots \ldots$ & $15,8 \mathrm{c}-\mathrm{e}$ & $11,0 \mathrm{c}-\mathrm{g}$ & $13,4 \mathrm{c}-\mathrm{e}$ & 20,3 b-f & $17,0 \mathrm{c}-\mathrm{e}$ & 18,6 b-d & $16,0 \mathrm{~d}-\mathrm{g}$ \\
\hline F (Gen.) & $8,29 *$ & $20,31 *$ & $8,88^{*}$ & $12,64 *$ & $7,35^{*}$ & $9,18^{*}$ & $13,62 *$ \\
\hline $\mathrm{F}$ (Anos) & - & - & $131,56^{*}$ & - & - & $101,33 *$ & - \\
\hline F (Ensaios) & - & - & - & - & - & - & $239,59 *$ \\
\hline$F(G \times A)$ & - & - & $2,54^{*}$ & - & - & 1,82 & - \\
\hline$F(G \times E)$ & - & - & - & - & - & - & $2,68^{*}$ \\
\hline d.m.s. ${ }^{(1)}$ & 3,07 & 2,85 & 3,85 & 2,31 & 3,01 & 2,81 & 2,37 \\
\hline C.V. (\%) & 7,33 & 8,66 & 8,33 & 4,40 & 6,46 & 5,43 & 6,70 \\
\hline
\end{tabular}

${ }^{(1)}$ Médias seguidas de, pelo menos, uma letra comum não diferem, entre si, pelo teste de Tukey.

* Significativo a $5 \%$. 
Tabela 13. Número de grãos por espiga dos genótipos avaliados no Ensaio de Linhagens Diaplóides de Trigo I, nas Estações Experimentais de Agronomia de Capão Bonito e Tatuí em 1999 e 2000.

\begin{tabular}{|c|c|c|c|c|c|c|c|}
\hline \multirow{3}{*}{ Genótipos } & \multicolumn{7}{|c|}{ Número de grãos por espiga } \\
\hline & \multicolumn{3}{|c|}{ Capão Bonito } & \multicolumn{3}{|c|}{ Tatuí } & \multirow{2}{*}{$\begin{array}{c}\text { Média } \\
\text { geral }\end{array}$} \\
\hline & 1999 & 2000 & Média & 1999 & 2000 & Média & \\
\hline & & & & $-\mathrm{n}^{\mathrm{o}}-$ & & & \\
\hline $1 \ldots \ldots \ldots \ldots$ & 41,7 & $24,2 \mathrm{c}-\mathrm{f}$ & $32,9 \mathrm{ab}$ & $54,5 \mathrm{a}-\mathrm{c}$ & $44,1 \mathrm{ab}$ & $49,3 \mathrm{ab}$ & $41,1 \mathrm{ab}$ \\
\hline $2 \ldots \ldots \ldots \ldots$ & 44,5 & $30,5 \mathrm{a}-\mathrm{d}$ & $37,5 \mathrm{ab}$ & $56,9 \mathrm{ab}$ & $47,3 \mathrm{ab}$ & $52,1 \mathrm{a}$ & $44,8 \mathrm{a}$ \\
\hline $3 \ldots \ldots \ldots \ldots \ldots$ & 42,6 & $30,2 \mathrm{a}-\mathrm{d}$ & $36,4 \mathrm{ab}$ & $60,6 \mathrm{a}$ & $42,3 \mathrm{a}-\mathrm{c}$ & $51,4 \mathrm{a}$ & $43,9 \mathrm{ab}$ \\
\hline ....... & 41,8 & $27,1 \mathrm{a}-\mathrm{f}$ & $34,5 \mathrm{ab}$ & 49,4 a-e & $44,1 \mathrm{ab}$ & $46,7 \mathrm{a}-\mathrm{c}$ & 40,6 a-c \\
\hline $5 \ldots \ldots \ldots \ldots \ldots \ldots$ & 48,2 & $32,0 \mathrm{a}-\mathrm{c}$ & $40,1 \mathrm{a}$ & 50,0 a-e & $45,0 \mathrm{ab}$ & $47,5 \mathrm{a}-\mathrm{c}$ & $43,8 \mathrm{ab}$ \\
\hline $6 \ldots \ldots \ldots \ldots \ldots$ & 41,2 & $26,2 \mathrm{a}-\mathrm{f}$ & $33,7 \mathrm{ab}$ & 51,0 a-e & $47,4 \mathrm{ab}$ & $49,2 \mathrm{ab}$ & $41,4 \mathrm{ab}$ \\
\hline $7 \ldots \ldots \ldots \ldots \ldots . . .$. & 39,4 & $24,8 \mathrm{~b}-\mathrm{f}$ & $32,1 \mathrm{ab}$ & $42,1 \mathrm{de}$ & $38,1 \mathrm{a}-\mathrm{c}$ & $40,1 \mathrm{a}-\mathrm{c}$ & $36,1 \mathrm{~b}-\mathrm{d}$ \\
\hline 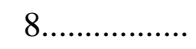 & 47,7 & 28,2 a-e & $37,9 \mathrm{ab}$ & $54,4 \mathrm{a}-\mathrm{c}$ & $43,2 \mathrm{a}-\mathrm{c}$ & $48,8 \mathrm{a}-\mathrm{c}$ & $43,3 \mathrm{ab}$ \\
\hline 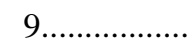 & 40,6 & $34,8 \mathrm{a}$ & $37,7 \mathrm{ab}$ & $52,2 \mathrm{a}-\mathrm{d}$ & $51,8 \mathrm{a}$ & $52,0 \mathrm{a}$ & $44,8 \mathrm{a}$ \\
\hline 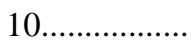 & 42,0 & $24,3 \mathrm{c}-\mathrm{f}$ & $33,2 \mathrm{ab}$ & 48,6 b-e & $41,1 \mathrm{a}-\mathrm{c}$ & $44,8 \mathrm{a}-\mathrm{c}$ & 39,0 a-d \\
\hline $11 \ldots \ldots \ldots \ldots \ldots . . .$. & 41,0 & $22,6 \mathrm{~d}-\mathrm{f}$ & $31,8 \mathrm{ab}$ & 48,1 b-e & 40,0 a-c & $44,1 \mathrm{a}-\mathrm{c}$ & 37,9 a-d \\
\hline $12 \ldots \ldots \ldots \ldots$ & 38,6 & 19,3 ef & $28,9 \mathrm{~b}$ & 48,6 b-e & $44,8 \mathrm{ab}$ & $46,7 \mathrm{a}-\mathrm{c}$ & 37,8 a-d \\
\hline $13 \ldots \ldots \ldots \ldots$ & 36,9 & 21,1 ef & $29,0 \mathrm{~b}$ & $40,0 \mathrm{e}$ & $32,6 \mathrm{bc}$ & $36,3 \mathrm{bc}$ & $32,6 \mathrm{~cd}$ \\
\hline $14 \ldots \ldots \ldots \ldots \ldots$ & 41,3 & $25,2 \mathrm{~b}-\mathrm{f}$ & $33,2 \mathrm{ab}$ & 50,2 a-e & $37,2 \mathrm{a}-\mathrm{c}$ & 43,7 a-c & 38,5 a-d \\
\hline $15 \ldots \ldots \ldots \ldots$ & 41,6 & $25,1 \mathrm{~b}-\mathrm{f}$ & $33,3 \mathrm{ab}$ & 51,6 a-e & $40,1 \mathrm{a}-\mathrm{c}$ & $45,8 \mathrm{a}-\mathrm{c}$ & 39,6 a-d \\
\hline $16 \ldots \ldots \ldots \ldots$ & 38,3 & $18,7 \mathrm{f}$ & $28,5 \mathrm{~b}$ & $42,2 \mathrm{de}$ & $28,6 \mathrm{c}$ & $35,4 \mathrm{c}$ & $31,9 \mathrm{~d}$ \\
\hline $17 \ldots \ldots \ldots$ & 38,2 & $24,3 \mathrm{c}-\mathrm{f}$ & $31,2 a b$ & 46,6 b-e & $38,2 \mathrm{a}-\mathrm{c}$ & $42,4 \mathrm{a}-\mathrm{c}$ & 36,8 a-d \\
\hline $18 \ldots \ldots . . . . . .$. & 47,2 & $33,3 \mathrm{ab}$ & $40,2 \mathrm{a}$ & 49,3 a-e & 42,0 a-c & $45,7 \mathrm{a}-\mathrm{c}$ & $42,9 \mathrm{ab}$ \\
\hline $19 \ldots \ldots \ldots$ & 43,4 & 20,3 ef & $31,8 \mathrm{ab}$ & 42,9 c-e & $38,9 \mathrm{a}-\mathrm{c}$ & 40,9 a-c & $36,3 \mathrm{~b}-\mathrm{d}$ \\
\hline $20 \ldots \ldots \ldots \ldots$ & 44,5 & $22,4 \mathrm{~d}-\mathrm{f}$ & $33,4 \mathrm{ab}$ & 54,0 a-c & 37,0 a-c & $45,5 \mathrm{a}-\mathrm{c}$ & 39,5 a-d \\
\hline F (Gen.) & 1,52 & $7,21 *$ & $3,44 *$ & $5,50^{*}$ & $3,39 *$ & $4,03^{*}$ & $5,70^{*}$ \\
\hline F (Anos) & - & - & $379,50^{*}$ & - & - & $65,51 *$ & - \\
\hline F (Ensaios) & - & - & - & - & - & - & $203,19^{*}$ \\
\hline$F(G \times A)$ & - & - & 1,19 & - & - & 1,63 & - \\
\hline$F(G \times E)$ & - & - & - & - & - & - & 1,57 \\
\hline d.m.s. ${ }^{(1)}$ & 13,48 & 8,97 & 10,76 & 11,66 & 15,07 & 13,46 & 8,21 \\
\hline C.V. $(\%)$ & 12,22 & 13,28 & 14,34 & 8,95 & 13,95 & 11,40 & 12,66 \\
\hline
\end{tabular}

${ }^{(1)}$ Médias seguidas de, pelo menos, uma letra comum não diferem, entre si, pelo teste de Tukey.

* Significativo a $5 \%$. 
Tabela 14. Número de grãos por espigueta dos genótipos avaliados no Ensaio de Linhagens Diaplóides de Trigo I, nas Estações Experimentais de Agronomia de Capão Bonito e Tatuí em 1999 e 2000.

\begin{tabular}{|c|c|c|c|c|c|c|c|}
\hline \multirow{3}{*}{ Genótipos } & \multicolumn{7}{|c|}{ Número de grãos por espigueta } \\
\hline & \multicolumn{3}{|c|}{ Capão Bonito } & \multicolumn{3}{|c|}{ Tatuí } & \multirow{2}{*}{$\begin{array}{c}\text { Média } \\
\text { geral }\end{array}$} \\
\hline & 1999 & 2000 & Média & 1999 & 2000 & Média & \\
\hline & & & & & & & \\
\hline $1 \ldots \ldots \ldots \ldots$ & $2,41 \mathrm{bc}$ & $1,97 \mathrm{~b}-\mathrm{d}$ & $2,19 \mathrm{~cd}$ & 2,49 a-e & $2,32 \mathrm{ab}$ & $2,40 \mathrm{a}-\mathrm{c}$ & $2,30 b-d$ \\
\hline $2 \ldots \ldots \ldots \ldots$ & $2,34 \mathrm{bc}$ & $1,88 \mathrm{~cd}$ & $2,11 \mathrm{~cd}$ & $2,64 \mathrm{a}-\mathrm{c}$ & $2,39 a b$ & $2,52 \mathrm{a}-\mathrm{c}$ & $2,31 \mathrm{~b}-\mathrm{d}$ \\
\hline $3 \ldots \ldots \ldots \ldots \ldots$ & $2,74 \mathrm{a}-\mathrm{c}$ & $2,30 \mathrm{a}-\mathrm{c}$ & $2,52 \mathrm{a}-\mathrm{d}$ & $2,92 \mathrm{a}$ & $2,26 a b$ & $2,59 \mathrm{ab}$ & $2,56 \mathrm{a}-\mathrm{d}$ \\
\hline $4 \ldots \ldots \ldots \ldots$ & $2,83 \mathrm{a}-\mathrm{c}$ & $2,33 \mathrm{a}-\mathrm{c}$ & $2,58 \mathrm{a}-\mathrm{c}$ & 2,56 a-e & $2,55 \mathrm{a}$ & $2,55 \mathrm{a}-\mathrm{c}$ & $2,57 \mathrm{a}-\mathrm{c}$ \\
\hline 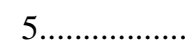 & $3,39 \mathrm{a}$ & $2,60 \mathrm{a}$ & $3,00 \mathrm{a}$ & $2,79 \mathrm{ab}$ & $2,45 a b$ & $2,62 \mathrm{ab}$ & $2,81 \mathrm{a}$ \\
\hline $6 \ldots \ldots \ldots \ldots \ldots$ & $2,59 \mathrm{bc}$ & $2,14 \mathrm{a}-\mathrm{d}$ & $2,37 \mathrm{~b}-\mathrm{d}$ & 2,57 a-e & $2,59 \mathrm{a}$ & $2,58 \mathrm{ab}$ & $2,47 \mathrm{a}-\mathrm{d}$ \\
\hline 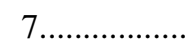 & $2,51 \mathrm{bc}$ & $1,90 \mathrm{~cd}$ & $2,21 \mathrm{~cd}$ & $2,09 \mathrm{de}$ & $2,07 \mathrm{ab}$ & $2,08 \mathrm{bc}$ & $2,14 \mathrm{~cd}$ \\
\hline 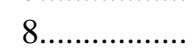 & $2,43 \mathrm{bc}$ & $1,65 \mathrm{~d}$ & $2,04 \mathrm{~d}$ & $2,33 \mathrm{~b}-\mathrm{e}$ & $2,07 \mathrm{ab}$ & $2,20 \mathrm{a}-\mathrm{c}$ & $2,12 \mathrm{~d}$ \\
\hline 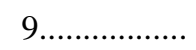 & $2,33 \mathrm{bc}$ & $2,03 \mathrm{a}-\mathrm{d}$ & $2,18 \mathrm{~cd}$ & $2,33 \mathrm{~b}-\mathrm{e}$ & $2,54 \mathrm{a}$ & $2,44 \mathrm{a}-\mathrm{c}$ & $2,31 \mathrm{~b}-\mathrm{d}$ \\
\hline $10 \ldots \ldots \ldots$ & $2,49 \mathrm{bc}$ & $2,13 \mathrm{a}-\mathrm{d}$ & $2,31 \mathrm{~b}-\mathrm{d}$ & $2,63 \mathrm{a}-\mathrm{c}$ & $2,44 a b$ & $2,54 \mathrm{a}-\mathrm{c}$ & $2,42 \mathrm{a}-\mathrm{d}$ \\
\hline $11 \ldots \ldots \ldots \ldots$ & $2,96 \mathrm{ab}$ & $2,53 \mathrm{ab}$ & $2,74 \mathrm{ab}$ & $2,61 \mathrm{a}-\mathrm{d}$ & $2,42 a b$ & $2,52 \mathrm{a}-\mathrm{c}$ & $2,63 a b$ \\
\hline 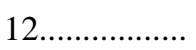 & $2,77 \mathrm{a}-\mathrm{c}$ & 2,14 a-d & $2,46 \mathrm{~b}-\mathrm{d}$ & $2,68 \mathrm{a}-\mathrm{c}$ & $2,76 \mathrm{a}$ & $2,72 \mathrm{a}$ & $2,59 \mathrm{ab}$ \\
\hline 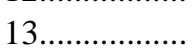 & $2,54 \mathrm{bc}$ & 2,14 a-d & $2,34 b-d$ & $2,06 \mathrm{e}$ & $1,81 \mathrm{~b}$ & $1,94 \mathrm{c}$ & $2,14 \mathrm{~cd}$ \\
\hline $14 \ldots \ldots \ldots \ldots \ldots$ & $2,88 \mathrm{a}-\mathrm{c}$ & 2,19 a-d & $2,53 \mathrm{a}-\mathrm{d}$ & $2,61 \mathrm{a}-\mathrm{c}$ & $2,15 a b$ & $2,38 \mathrm{a}-\mathrm{c}$ & 2,46 a-d \\
\hline $15 \ldots \ldots \ldots \ldots$ & $2,59 \mathrm{bc}$ & $2,10 \mathrm{a}-\mathrm{d}$ & $2,34 \mathrm{~b}-\mathrm{d}$ & $2,59 \mathrm{a}-\mathrm{d}$ & $2,28 \mathrm{ab}$ & $2,43 \mathrm{a}-\mathrm{c}$ & $2,39 \mathrm{a}-\mathrm{d}$ \\
\hline $16 \ldots \ldots \ldots \ldots$ & $2,75 a-c$ & $2,00 \mathrm{a}-\mathrm{d}$ & $2,38 \mathrm{~b}-\mathrm{d}$ & $2,41 \mathrm{a}-\mathrm{e}$ & $2,15 a b$ & $2,28 \mathrm{a}-\mathrm{c}$ & $2,33 \mathrm{~b}-\mathrm{d}$ \\
\hline $17 \ldots \ldots \ldots \ldots$ & $2,24 \mathrm{c}$ & $1,82 \mathrm{~cd}$ & $2,03 \mathrm{~d}$ & 2,31 b-e & $2,14 a b$ & $2,23 \mathrm{a}-\mathrm{c}$ & $2,13 \mathrm{~cd}$ \\
\hline 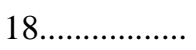 & $2,69 \mathrm{bc}$ & 2,09 a-d & $2,39 \mathrm{~b}-\mathrm{d}$ & $2,30 \mathrm{~b}-\mathrm{e}$ & $2,45 a b$ & $2,37 \mathrm{a}-\mathrm{c}$ & $2,38 \mathrm{a}-\mathrm{d}$ \\
\hline $19 \ldots \ldots \ldots$ & $2,59 \mathrm{bc}$ & $1,59 \mathrm{~d}$ & $2,09 \mathrm{~cd}$ & $2,20 \mathrm{c}-\mathrm{e}$ & $2,17 a b$ & $2,19 \mathrm{a}-\mathrm{c}$ & $2,14 \mathrm{~cd}$ \\
\hline 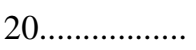 & $2,82 \mathrm{a}-\mathrm{c}$ & $2,03 \mathrm{a}-\mathrm{d}$ & $2,42 \mathrm{~b}-\mathrm{d}$ & $2,67 \mathrm{a}-\mathrm{c}$ & $2,18 a b$ & $2,43 \mathrm{a}-\mathrm{c}$ & $2,42 a-d$ \\
\hline F (Gen.) & $4,05^{*}$ & $4,66^{*}$ & $6,91^{*}$ & $5,25^{*}$ & $2,67 *$ & $3,21^{*}$ & $4,98 *$ \\
\hline F (Anos) & - & - & $191,27 *$ & - & - & $13,36^{*}$ & - \\
\hline F (Ensaios) & - & - & - & - & - & - & $40,37^{*}$ \\
\hline$F(G \times A)$ & - & - & 1,01 & - & - & 1,68 & - \\
\hline$F(G \times E)$ & - & - & - & - & - & - & $1,90^{*}$ \\
\hline d.m.s. ${ }^{(1)}$ & 0,69 & 0,61 & 0,53 & 0,53 & 0,72 & 0,63 & 0,45 \\
\hline C.V. (\%) & 9,94 & 11,21 & 10,94 & 8,04 & 11,81 & 10,01 & 10,48 \\
\hline
\end{tabular}

${ }^{(1)}$ Médias seguidas de, pelo menos, uma letra comum não diferem, entre si, pelo teste de Tukey.

* Significativo a $5 \%$. 
Tabela 15. Massa de cem grãos dos genótipos avaliados no Ensaio de Linhagens Diaplóides de Trigo I, nas Estações Experimentais de Agronomia de Capão Bonito e Tatuí em 1999 e 2000.

\begin{tabular}{|c|c|c|c|c|c|c|c|}
\hline \multirow{3}{*}{ Genótipos } & \multicolumn{7}{|c|}{ Massa de cem grãos } \\
\hline & \multicolumn{3}{|c|}{ Capão Bonito } & \multicolumn{3}{|c|}{ Tatuí } & \multirow{2}{*}{$\begin{array}{c}\text { Média } \\
\text { geral }\end{array}$} \\
\hline & 1999 & 2000 & Média & 1999 & 2000 & Média & \\
\hline $1 \ldots$ & $3,47 \mathrm{gh}$ & $2,95 \mathrm{a}$ & 3,21 & $2,96 \mathrm{e}-\mathrm{g}$ & 3,24 a-d & $3,10 \mathrm{~b}$ & $3,15 \mathrm{a}-\mathrm{c}$ \\
\hline $2 .$. & $3,60 \mathrm{~d}-\mathrm{h}$ & $2,56 a-d$ & 3,08 & $3,08 \mathrm{~d}-\mathrm{g}$ & $3,34 \mathrm{a}-\mathrm{d}$ & $3,21 \mathrm{~b}$ & $3,15 \mathrm{a}-\mathrm{c}$ \\
\hline $3 \ldots \ldots \ldots \ldots$ & $3,71 \mathrm{c}-\mathrm{g}$ & 2,58 a-d & 3,15 & $3,85 \mathrm{a}-\mathrm{c}$ & $2,81 \mathrm{~b}-\mathrm{d}$ & $3,33 \mathrm{~b}$ & $3,24 a-c$ \\
\hline $4 \ldots \ldots \ldots \ldots$ & $3,59 \mathrm{e}-\mathrm{h}$ & 2,43 a-e & 3,01 & $3,76 \mathrm{a}-\mathrm{c}$ & $3,62 \mathrm{a}-\mathrm{c}$ & $3,69 \mathrm{ab}$ & $3,35 a-c$ \\
\hline $5 \ldots \ldots \ldots \ldots \ldots$ & $3,99 \mathrm{~b}-\mathrm{g}$ & $2,78 \mathrm{a}-\mathrm{c}$ & 3,39 & 3,86 a-c & $3,85 \mathrm{ab}$ & $3,86 a b$ & $3,62 \mathrm{a}$ \\
\hline $6 \ldots \ldots \ldots \ldots \ldots . .$. & 4,35 a-c & $2,67 \mathrm{a}-\mathrm{c}$ & 3,51 & $3,98 \mathrm{ab}$ & $2,67 \mathrm{c}-\mathrm{e}$ & $3,32 \mathrm{~b}$ & $3,42 a b$ \\
\hline 7....................... & 4,02 b-g & $2,35 b-f$ & 3,19 & 3,54 a-e & $2,80 \mathrm{~b}-\mathrm{d}$ & $3,17 \mathrm{~b}$ & $3,18 \mathrm{a}-\mathrm{c}$ \\
\hline $8 \ldots \ldots \ldots \ldots \ldots \ldots$ & $3,79 \mathrm{c}-\mathrm{g}$ & $1,92 \mathrm{e}-\mathrm{g}$ & 2,85 & $3,20 \mathrm{c}-\mathrm{f}$ & $3,21 \mathrm{a}-\mathrm{d}$ & $3,21 \mathrm{~b}$ & $3,03 \mathrm{a}-\mathrm{c}$ \\
\hline $9 \ldots \ldots \ldots \ldots \ldots$ & $3,47 \mathrm{gh}$ & $2,62 \mathrm{a}-\mathrm{d}$ & 3,05 & $3,43 \mathrm{~b}-\mathrm{e}$ & 3,66 a-c & $3,54 a b$ & $3,29 a-c$ \\
\hline $10 \ldots \ldots \ldots \ldots$ & $2,93 \mathrm{~h}$ & $2,67 \mathrm{a}-\mathrm{c}$ & 2,80 & $2,49 \mathrm{~g}$ & $2,34 \mathrm{de}$ & $2,42 \mathrm{~b}$ & $2,61 \mathrm{bc}$ \\
\hline $11 \ldots \ldots \ldots \ldots . . . .$. & $3,64 \mathrm{c}-\mathrm{h}$ & $2,10 \mathrm{~d}-\mathrm{g}$ & 2,87 & 3,74 a-d & 2,99 a-d & $3,36 \mathrm{~b}$ & $3,12 \mathrm{a}-\mathrm{c}$ \\
\hline $12 \ldots \ldots \ldots \ldots$ & $3,71 \mathrm{c}-\mathrm{g}$ & $1,86 \mathrm{fg}$ & 2,78 & $3,69 a-d$ & $3,02 \mathrm{a}-\mathrm{d}$ & $3,35 \mathrm{~b}$ & $3,07 \mathrm{a}-\mathrm{c}$ \\
\hline $13 \ldots \ldots \ldots \ldots$ & $3,49 \mathrm{gh}$ & $1,75 \mathrm{~g}$ & 2,62 & $2,94 \mathrm{e}-\mathrm{g}$ & $1,63 \mathrm{e}$ & $2,28 \mathrm{~b}$ & $2,45 \mathrm{c}$ \\
\hline $14 \ldots \ldots \ldots \ldots \ldots$ & $4,96 \mathrm{a}$ & 2,43 a-e & 3,69 & $4,16 \mathrm{a}$ & $3,94 \mathrm{a}$ & $4,05 \mathrm{a}$ & $3,87 \mathrm{a}$ \\
\hline $15 \ldots \ldots \ldots \ldots \ldots$ & $4,59 a b$ & $2,73 a-c$ & 3,66 & $3,94 a b$ & 3,33 a-d & $3,63 a b$ & $3,65 \mathrm{a}$ \\
\hline $16 \ldots \ldots \ldots \ldots \ldots$ & 4,30 a-d & $2,88 \mathrm{ab}$ & 3,59 & $3,88 \mathrm{ab}$ & $3,41 \mathrm{a}-\mathrm{d}$ & $3,65 a b$ & $3,62 \mathrm{a}$ \\
\hline $17 \ldots \ldots \ldots \ldots \ldots$ & 4,28 a-e & $2,26 \mathrm{c}-\mathrm{g}$ & 3,27 & 3,50 a-e & $3,47 \mathrm{a}-\mathrm{c}$ & $3,48 a b$ & 3,37 a-c \\
\hline $18 \ldots \ldots \ldots \ldots . . .$. & $3,67 \mathrm{c}-\mathrm{g}$ & 2,44 a-d & 3,05 & $2,63 \mathrm{fg}$ & $3,64 \mathrm{a}-\mathrm{c}$ & $3,14 b$ & $3,09 \mathrm{a}-\mathrm{c}$ \\
\hline $19 \ldots \ldots \ldots \ldots$ & $4,10 b-f$ & 2,56 a-d & 3,33 & $3,80 \mathrm{a}-\mathrm{c}$ & 3,16 a-d & $3,48 a b$ & $3,41 \mathrm{a}-\mathrm{c}$ \\
\hline $20 \ldots \ldots \ldots \ldots \ldots$ & $4,09 \mathrm{~b}-\mathrm{g}$ & $2,01 \mathrm{e}-\mathrm{g}$ & 3,05 & 3,60 a-e & 3,39 a-d & $3,50 a b$ & $3,28 \mathrm{a}-\mathrm{c}$ \\
\hline F (Gen.) & $11,43^{*}$ & $11,09 *$ & 1,23 & $13,26^{*}$ & $6,92 *$ & $2,10^{*}$ & $3,25^{*}$ \\
\hline F (Anos) & - & - & $142,67^{*}$ & - & - & $6,39 *$ & - \\
\hline F (Ensaios) & - & - & - & - & - & - & $56,54^{*}$ \\
\hline$F(G \times A)$ & - & - & $9,82 *$ & - & - & $5,39 *$ & - \\
\hline$F(G \times E)$ & - & - & - & - & - & - & $5,89^{*}$ \\
\hline d.m.s. ${ }^{(1)}$ & 0,72 & 0,54 & 1,57 & 0,68 & 1,09 & 1,66 & 0,96 \\
\hline C.V. $(\%)$ & 7,05 & 8,55 & 7,82 & 7,35 & 13,04 & 10,54 & 9,36 \\
\hline
\end{tabular}

${ }^{(1)}$ Médias seguidas de, pelo menos, uma letra comum não diferem, entre si, pelo teste de Tukey

* Significativo a $5 \%$. 
Considerando-se em conjunto os ensaios semeados em Tatuí, verificaram-se efeitos significativos apenas para genótipos e para anos. A interação genótipos x anos, não significativa, indicou que, apesar da diferença entre os anos, os genótipos com espigas mais compridas, em 1999, também tenderam a apresentar as espigas mais compridas no ano seguinte.

Comparando-se as médias de comprimento da espiga dos ensaios de Tatuí, em 1999 e 2000, verifica-se que a linhagem $2(10,3 \mathrm{~cm})$ apresentou as espigas mais compridas, não diferindo das linhagens $1,4,5,13,14$ e 18.

Na Tabela 12, verifica-se, pela análise da variância do número de espiguetas por espiga, tomados em conjunto os quatro ensaios, efeitos significativos para genótipos, para ensaios e para a interação genótipos x ensaios, indicando que essa característica foi influenciada pelo ambiente em que se avaliaram os genótipos. Apesar da interação significativa, na média dos quatro ensaios, a linhagem $8(20,2)$ mostrou o maior número de espiguetas por espiga, não diferindo apenas das linhagens $2(19,1), 9(19,2)$ e 18 $(18,0)$. A 8, também apresentou o maior número de espiguetas por espiga quando os ensaios foram considerados individualmente, e poderia ser utilizada em programas de melhoramento para a característica número de espiguetas por espiga, pois, além do grande número de espiguetas também se revelou estável em relação a essa característica.

Quando se consideraram somente os ensaios de Capão Bonito, em ambos os anos, a análise da variância mostrou efeitos significativos para genótipos, para anos e para a interação genótipos $\mathrm{x}$ anos.

Na comparação das médias dos genótipos de Capão Bonito, a linhagem 8 $(18,4)$ apresentou o maior número de espiguetas por espiga, não diferindo, porém, dos genótipos 1, 2, 9, 17, 18 e 19, com um número de espiguetas por espiga variando de 14,7 a 17,5 .

Em 1999, destacou-se a linhagem 8 (19,7), não diferindo das linhagens 1, 2, 9, 10, 17 e 18, cujo número de espiguetas por espiga variou de 16,8 a 19,0. Em 2000, destacaram-se as linhagens 8 e $9(17,1)$, não diferindo somente das linhagens 2 e 18 , com 16,0 espiguetas por espiga.

Os ensaios semeados em Tatuí, quando analisados em conjunto, mostraram efeitos significativos apenas para genótipos e para anos. 
Na comparação das médias desses genótipos, destacou-se a linhagem $8(22,0)$ com o maior número de espiguetas por espiga, não diferindo apenas das linhagens 1,2 , 3, 7, 9 e 18, com um número de espiguetas por espiga entre 19,3 e 21,2.

Os dados da análise da variância para número de grãos por espiga, considerando-se em conjunto os quatro ensaios, encontram-se na Tabela 13. Verificam-se efeitos significativos para genótipos e para ensaios, e não significativos para a interação genótipos x ensaios.

Comparando-se as médias de número de grãos por espiga dos quatro ensaios, destacaram-se as linhagens 2 e $9(44,8)$, com o maior número de grãos por espiga, diferindo somente dos genótipos $7(36,1), 13(32,6), 16(31,9)$ e $19(36,3)$.

Os dados da análise da variância para o número de grãos por espigueta, quando considerados em conjunto os quatro ensaios, acham-se na Tabela 14. Pode-se verificar efeitos significativos para genótipos, para ensaios e para a interação genótipos $\mathrm{x}$ ensaios.

A linhagem $5(2,81)$ exibiu o maior número de grãos por espigueta, diferindo somente dos genótipos 1, 2, 7, 8, 9, 13, 16, 17 e 19, cujo número de grãos por espigueta variou de 2,12 a 2,33, quando avaliados em conjunto os quatro ensaios.

A análise da variância envolvendo os ensaios de Capão Bonito mostrou efeitos significativos somente para genótipos e para anos. A linhagem $5(3,00)$ destacou-se quanto ao número de grãos por espigueta, não diferindo apenas dos genótipos 3 (2,52), 4 (2,58), $11(2,74)$ e 14 (2,53).

Os dados obtidos em Tatuí, considerando-se os dois anos, exibiram, mediante a análise da variância efeitos significativos apenas para genótipos e para anos. A linhagem $12(2,72)$ destacou-se pelo maior número de grãos por espigueta, diferindo somente das linhagens $7(2,08)$ e $13(1,94)$.

A análise da variância, considerando-se os dados médios de massa de cem grãos, quando tomados em conjunto os quatro ensaios, mostraram efeitos significativos para genótipos, para ensaios e para a interação genótipos x ensaios (Tabela 15).

Na média dos quatro ensaios, os genótipos 5 (3,62 g), 14 (3,87 g), 15 (3,65 g) e $16(3,62 \mathrm{~g})$ apresentaram os grãos mais pesados, diferindo somente dos genótipos 10 $(2,61 \mathrm{~g})$ e 13 (2,45 g), com os grãos mais leves. 
Considerando-se em conjunto os ensaios de Capão Bonito, verificaram-se efeitos significativos somente para anos e para a interação genótipos x anos. Não se observou diferença significativa entre os genótipos pelo teste de Tukey a 5\%, quando avaliados em conjunto os dois ensaios.

Em 1999, a linhagem 14 (4,96 g) apresentou os grãos mais pesados, não diferindo das linhagens $6,15,16$ e 17, com a massa de cem grãos variando entre 4,28 e 4,59 g. Em 2000, destacou-se a linhagem 1 (2,95 g), diferindo dos genótipos 7, 8, 11, 12, 13, 17 e 20, com a massa de cem grãos entre 1,75 e 2,35 g.

Em Tatuí, a análise da variância apresentou efeitos significativos para genótipos, para anos e para a interação genótipos x anos, indicando que os genótipos apresentaram comportamento diferencial em relação aos anos em que foram avaliados.

A linhagem 14 (4,05 g) exibiu os grãos mais pesados, não diferindo dos genótipos 4, 5, 9, 15, 16, 17, 19 e 20, que mostraram massa de cem grãos variando de 3,48 a 3,86 g, quando analisados em conjunto os ensaios instalados em Tatuí.

Em 1999, destacou-se a linhagem 14 (4,16 g), diferindo dos genótipos 1, 2, 8, 9, 10, 13 e 18, com uma massa de cem grãos inferior a 3,44 g. Em 2000, destacou-se a $14(3,94 \mathrm{~g})$, diferindo somente das linhagens 3, 6, 7, 10 e 13, com a massa de cem grãos inferior a $2,82 \mathrm{~g}$.

A interação genótipos x ensaios, verificada na análise da variância para as características comprimento da espiga, número de espiguetas e de grãos por espiga e por espigueta e massa de cem grãos, também foi verificada em trabalhos de avaliação de novos genótipos no Estado de São Paulo por Camargo et al. (1991b).

Os dados de comprimento médio das raízes dos genótipos avaliados no Ensaio de Linhagens Diaplóides de Trigo I e dos cultivares controle Anahuac e BH-1146, após 72 horas de crescimento em solução normal, que se seguiu a um crescimento em solução-tratamento contendo seis diferentes concentrações de alumínio, resultantes da média de cinco repetições, encontram-se na Tabela 16.

Observou-se grande variabilidade no crescimento das raízes dos genótipos avaliados, quanto ao crescimento das raízes, nas diferentes concentrações de alumínio. Observou-se, ainda, uma tendência de diminuição do comprimento das raízes à medida que se aumentou a concentração de alumínio nas soluções (Tabela 16). 
Em solução nutritiva com ausência de alumínio, todos os genótipos apresentaram crescimento normal das raízes; a diferença verificada entre o comprimento das raízes dos genótipos avaliados nessa condição deve-se à constituição genética de cada um.

Nas soluções contendo 2 e $4 \mathrm{mg} \mathrm{L}^{-1}$, apenas o cultivar-controle Anahuac apresentou paralisação irreversível do meristema da raiz primária central, sendo considerado suscetível. Nos demais genótipos, houve redução de crescimento, mostrando tolerância a essas concentrações.

O genótipo 20 (IAC-289) apresentou paralisação do crescimento da raiz após tratamento com solução contendo 6 e $8 \mathrm{mg} \mathrm{L}^{-1}$, sendo considerado sensível a tais concentrações. Os demais genótipos revelaram-se tolerantes por apresentar crescimento de raízes após tratamento nessas concentrações, exceto a linhagem 13, que também se mostrou sensível a $8 \mathrm{mg} \mathrm{L}^{-1}$.

$\mathrm{Na}$ concentração contendo $10 \mathrm{mg} \mathrm{L}^{-1}$, todos os genótipos apresentaram crescimento de raízes, sendo considerados tolerantes a essa concentração, exceto os genótipos 13 e 20 e o cultivar Anahuac, os únicos a não apresentar crescimento de raízes, sendo, portanto, sensíveis a essa concentração.

O genótipo 20 (IAC-289), sensível à concentração de $6 \mathrm{mg} \mathrm{L}^{-1}$ e com um dos menores comprimentos de raiz a $4 \mathrm{mg} \mathrm{L}^{-1}$, foi um dos mais produtivos em Capão Bonito (solo ácido e em condição de sequeiro), em 1999, ano em que não ocorreram grandes deficiências hídricas durante o ciclo da cultura. A tolerância à concentração de $4 \mathrm{mg} \mathrm{L}^{-1}$, portanto, foi suficiente para permitir o desenvolvimento dos genótipos em condição de solo ácido e de baixa fertilidade, como a encontrada em Capão Bonito.

Os ensaios da Estação Experimental de Agronomia de Tatuí foram instalados em solo ácido com aplicação de calcário e com irrigação por aspersão, mantendo as raízes dos genótipos em quase sua totalidade na camada arável. Isso impediu que a provável presença de alumínio no subsolo representasse um fator de limitação para o desenvolvimento dos genótipos avaliados. 
Tabela 16. Comprimento médio das raízes dos genótipos avaliados no Ensaio de Linhagens Diaplóides de Trigo I, após 72 horas de crescimento em solução normal, que se seguiu a um crescimento em solução tratamento contendo seis concentrações de alumínio (média de cinco repetições).

\begin{tabular}{|c|c|c|c|c|c|c|}
\hline \multirow{2}{*}{ Genótipos } & \multicolumn{6}{|c|}{ Concentração de alumínio $\left(\mathrm{mg} \mathrm{L}^{-1}\right)$} \\
\hline & 0 & 2 & 4 & 6 & 8 & 10 \\
\hline $1 \ldots \ldots \ldots \ldots$ & 57,5 & 17,6 & 6,1 & 1,5 & 0,4 & 0,3 \\
\hline 2. & 68,5 & 13,1 & 5,4 & 3,3 & 0,3 & 0,6 \\
\hline $3 \ldots \ldots \ldots \ldots \ldots \ldots$ & 61,8 & 36,4 & 26,9 & 17,4 & 15,9 & 11,2 \\
\hline $4 \ldots \ldots \ldots \ldots$ & 65,8 & 43,6 & 34,7 & 26,9 & 16,3 & 14,4 \\
\hline $5 \ldots \ldots \ldots \ldots \ldots \ldots$ & 63,3 & 40,9 & 32,6 & 25,6 & 16,4 & 13,2 \\
\hline $6 \ldots \ldots \ldots \ldots \ldots \ldots$ & 60,2 & 40,8 & 32,5 & 18,9 & 12,3 & 10,1 \\
\hline $7 \ldots \ldots \ldots \ldots \ldots \ldots$ & 69,5 & 39,5 & 21,9 & 8,0 & 4,7 & 1,8 \\
\hline 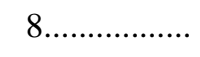 & 68,5 & 43,0 & 25,6 & 17,4 & 15,5 & 5,0 \\
\hline $9 \ldots \ldots$. & 66,9 & 43,0 & 26,3 & 19,4 & 11,5 & 8,0 \\
\hline $10 \ldots \ldots \ldots \ldots$ & 66,9 & 40,1 & 26,5 & 19,9 & 9,9 & 10,1 \\
\hline $11 \ldots \ldots \ldots \ldots$ & 73,7 & 40,5 & 24,8 & 18,0 & 14,7 & 9,6 \\
\hline $12 .$. & 71,3 & 40,4 & 21,9 & 24,4 & 14,0 & 10,1 \\
\hline $13 \ldots \ldots \ldots . . . . .$. & 61,1 & 6,1 & 3,3 & 0,7 & 0,0 & 0,0 \\
\hline $14 \ldots \ldots \ldots \ldots \ldots$ & 74,0 & 58,0 & 16,4 & 13,3 & 12,2 & 7,2 \\
\hline $15 \ldots \ldots \ldots \ldots$ & 66,5 & 16,6 & 9,0 & 5,0 & 3,1 & 4,6 \\
\hline $16 \ldots \ldots \ldots \ldots$ & 81,9 & 51,0 & 23,2 & 14,5 & 11,6 & 7,9 \\
\hline $17 \ldots \ldots \ldots \ldots \ldots$ & 62,4 & 41,8 & 18,1 & 8,7 & 10,5 & 7,4 \\
\hline $18 \ldots \ldots \ldots \ldots . . . .$. & 73,6 & 40,9 & 22,2 & 18,4 & 16,1 & 11,6 \\
\hline $19 \ldots \ldots \ldots \ldots \ldots . .$. & 77,7 & 50,7 & 44,0 & 34,3 & 24,2 & 19,5 \\
\hline $20 \ldots \ldots \ldots \ldots \ldots . . .$. & 81,5 & 28,8 & 6,9 & 0,0 & 0,0 & 0,0 \\
\hline BH-1146..... & 90,7 & 75,3 & 55,1 & 44,8 & 23,4 & 12,6 \\
\hline Anahuac....... & 87,6 & 0,0 & 0,0 & 0,0 & 0,0 & 0,0 \\
\hline
\end{tabular}


Já nos ensaios de Capão Bonito, em condição de sequeiro e solo ácido sem aplicação de calcário, a presença de alumínio na camada arável prejudicou o desenvolvimento dos genótipos, como se pode observar comparando-se as produções dos dois locais em 1999, quando as condições climáticas não foram tão adversas quanto as do ano seguinte (Tabela 4).

As correlações entre as médias de produção de grãos de cada genótipo, em Capão Bonito, considerando-se os dois anos, e o comprimento médio das raízes em cada concentração de alumínio, apresentaram resultados significativos e positivos $\left(0,54^{*}<\mathrm{r}\right.$ $\left.<0,67^{*}\right)$ para todas as concentrações, exceto para a ausência de alumínio, mostrando uma relação significativa entre os resultados em solução nutritiva e aqueles no campo.

Os resultados em solução nutritiva sugerem que todos os genótipos avaliados no Ensaio de Linhagens Diaplóides de Trigo I poderiam ser semeados em condição de sequeiro e solo ácido com alto teor de alumínio visando a uma produção econômica.

\subsection{Ensaio de Linhagens Diaplóides de Trigo II}

O Ensaio de Linhagens Diaplóides de Trigo II foi instalado nas Estações Experimentais de Agronomia de Monte Alegre do Sul e de Tatuí (solos ácidos, com aplicação de calcário e em condição de irrigação por aspersão).

Em Tatuí, em 2000, quando comparado ao ano anterior, apresentou condições de clima desfavoráveis ao desenvolvimento de diversas culturas, inclusive o trigo, como demonstrado para o Ensaio I.

Na Figura 3, encontram-se as temperaturas mínimas mensais (medidas no abrigo meteorológico), ocorridas de maio a outubro na Estação Experimental de Agronomia de Monte Alegre do Sul em 1999 e 2000. Os dados mostram que, em 2000, as temperaturas mínimas mensais foram inferiores às registradas no mesmo período em 1999. As temperaturas mais baixas em julho de 2000 ocorreram nas noites de 17 $\left(-0,6^{\circ} \mathrm{C}\right), 18\left(0,8^{\circ} \mathrm{C}\right), 19\left(0^{\circ} \mathrm{C}\right)$ e $21\left(0,4^{\circ} \mathrm{C}\right)$.

As produções médias de grãos dos genótipos dos ensaios de Monte Alegre do Sul e Tatuí, em 1999 e 2000, encontram-se na Tabela 17. Verifica-se que, de modo geral, os dados obtidos em 2000 foram inferiores, possivelmente em função das fortes 
geadas em Tatuí, e do excesso de chuvas na época de maturação e colheita em Monte Alegre do Sul.

Considerando-se a média dos quatro Ensaios de Linhagens Diaplóides de Trigo II instalados de Monte Alegre do Sul e Tatuí, nos dois anos, observaram-se efeitos significativos para genótipos, para ensaios e para a interação genótipos x ensaios.

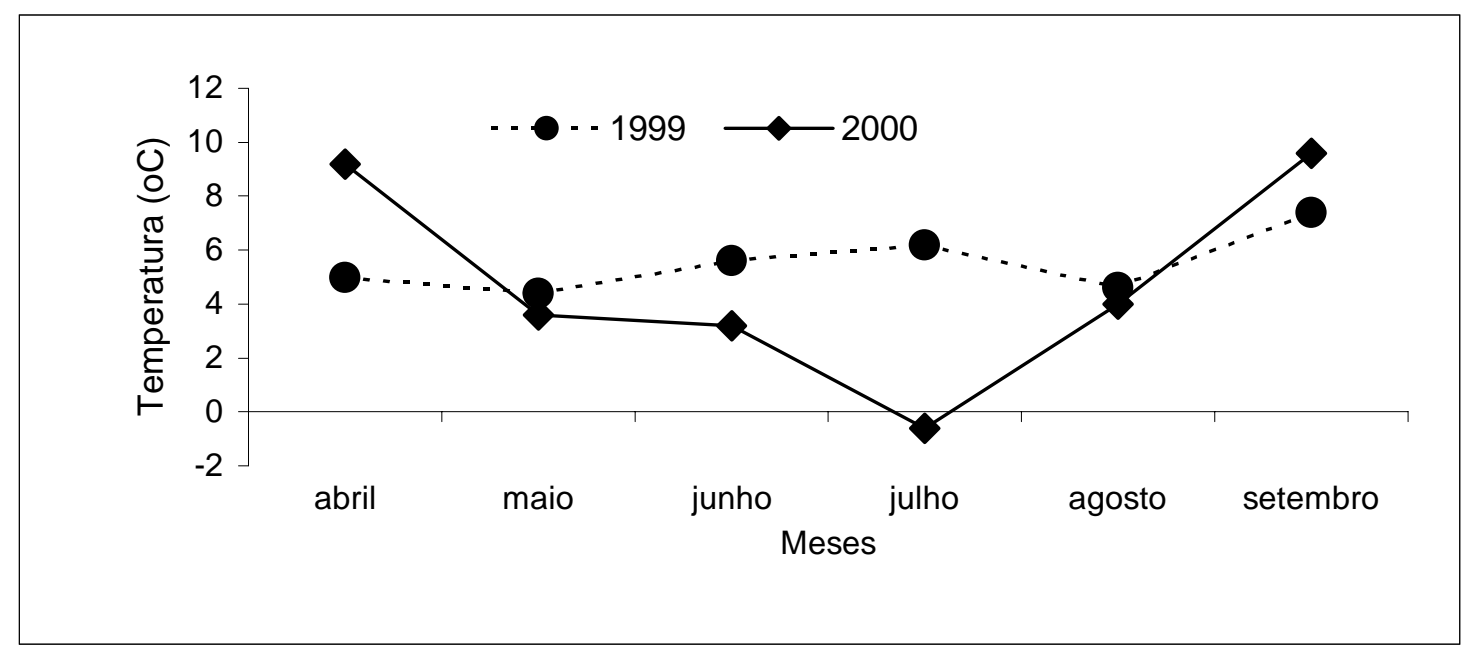

Figura 3 - Temperaturas mínimas mensais de maio a setembro na Estação Experimental de Monte Alegre do Sul em 1999 e 2000.

A interação genótipos x ensaios para produção de grãos também foi verificada por Camargo et al. (1990), estudando linhagens de trigo no Vale do Paranapanema, e Camargo et al. (1991a), na avaliação de genótipos oriundos de populações híbridas introduzidas de Oregon (EUA) no Estado de São Paulo.

Apesar da interação significativa genótipos x ensaios, nota-se que o cultivar IAC-289 e a linhagem 8 estão sempre entre os mais produtivos nos quatro ensaios.

Considerando-se as médias dos quatro ensaios, os genótipos $8\left(3.311 \mathrm{~kg} \mathrm{ha}^{-1}\right)$ e 20 (3.341 $\mathrm{kg} \mathrm{ha}^{-1}$ ) foram os mais produtivos, diferindo, apenas, das linhagens 3 (1.572 $\left.\mathrm{kg} \mathrm{ha}^{-1}\right), 13\left(1.380 \mathrm{~kg} \mathrm{ha}^{-1}\right)$ e $16\left(1.673 \mathrm{~kg} \mathrm{ha}^{-1}\right)$ e $18\left(1.852 \mathrm{~kg} \mathrm{ha}^{-1}\right)$. 
Tabela 17. Produção de grãos dos genótipos avaliados no Ensaio de Linhagens Diaplóides de Trigo II, nas Estações Experimentais de Agronomia de Monte Alegre do Sul e Tatuí em 1999 e 2000.

\begin{tabular}{|c|c|c|c|c|c|c|c|}
\hline \multirow{3}{*}{ Genótipos } & \multicolumn{7}{|c|}{ Produção de grãos } \\
\hline & \multicolumn{3}{|c|}{ Monte Alegre do Sul } & \multicolumn{3}{|c|}{ Tatuí } & \multirow{2}{*}{$\begin{array}{l}\text { Média } \\
\text { geral }\end{array}$} \\
\hline & 1999 & 2000 & Média & 1999 & 2000 & Média & \\
\hline & & & & - $\mathrm{kg} \mathrm{ha}^{-1}$ & & & \\
\hline $1 \ldots$ & $4143 \mathrm{a}-\mathrm{d}$ & 2038 a-d & 3090 a-d & 3896 a & $1375 \mathrm{ab}$ & $2635 \mathrm{a}$ & $2863 \mathrm{a}-\mathrm{c}$ \\
\hline$\ldots$ & $2861 \mathrm{~d}-\mathrm{g}$ & $1247 \mathrm{de}$ & 2054 d-f & 3055 a-e & $2021 \mathrm{ab}$ & $2538 \mathrm{a}$ & $2296 \mathrm{a}-\mathrm{d}$ \\
\hline $3 \ldots \ldots \ldots \ldots \ldots$ & $1754 \mathrm{~g}$ & $688 \mathrm{e}$ & $1221 \mathrm{f}$ & 2014 ef & $1834 \mathrm{ab}$ & $1924 \mathrm{ab}$ & $1572 \mathrm{~cd}$ \\
\hline$\ldots \ldots$ & 3552 b-f & $1403 \mathrm{c}-\mathrm{e}$ & 2477 c-f & 2938 a-e & $1958 \mathrm{ab}$ & 2448 a & $2463 \mathrm{a}-\mathrm{d}$ \\
\hline ......... & $2535 \mathrm{e}-\mathrm{g}$ & $1691 \mathrm{c}-\mathrm{e}$ & $2113 c-f$ & $2327 \mathrm{c}-\mathrm{f}$ & $1702 \mathrm{ab}$ & $2014 \mathrm{ab}$ & $2063 \mathrm{a}-\mathrm{d}$ \\
\hline$\ldots \ldots \ldots$ & $4094 \mathrm{a}-\mathrm{d}$ & $2101 \mathrm{a}-\mathrm{d}$ & 3097 a-d & $2396 \mathrm{c}-\mathrm{f}$ & $1396 \mathrm{ab}$ & $1896 \mathrm{ab}$ & $2497 \mathrm{a}-\mathrm{d}$ \\
\hline $7 \ldots \ldots \ldots$ & 3983 a-e & 2639 a-c & $3311 \mathrm{a}-\mathrm{c}$ & 3048 a-e & $1570 \mathrm{ab}$ & $2309 \mathrm{ab}$ & $2810 \mathrm{a}-\mathrm{c}$ \\
\hline 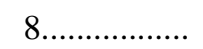 & $4768 \mathrm{ab}$ & $3017 \mathrm{ab}$ & $3892 \mathrm{ab}$ & $3271 \mathrm{a}-\mathrm{d}$ & $2187 \mathrm{a}$ & $2729 a$ & 3311 a \\
\hline $9 \ldots \ldots \ldots \ldots \ldots$ & $4354 \mathrm{a}-\mathrm{c}$ & $2302 \mathrm{a}-\mathrm{d}$ & 3328 a-c & 2917 a-e & $1577 \mathrm{ab}$ & $2247 \mathrm{ab}$ & $2787 \mathrm{a}-\mathrm{c}$ \\
\hline $10 \ldots \ldots \ldots \ldots . . . . . .$. & 3896 a-f & 2097 a-d & 2996 a-e & 2222 d-f & $1285 \mathrm{~b}$ & $1753 \mathrm{ab}$ & $2375 \mathrm{a}-\mathrm{d}$ \\
\hline 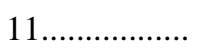 & $4254 \mathrm{a}-\mathrm{d}$ & $2163 \mathrm{a}-\mathrm{d}$ & $3208 \mathrm{a}-\mathrm{d}$ & $2604 \mathrm{c}-\mathrm{f}$ & $1584 \mathrm{ab}$ & $2094 \mathrm{ab}$ & $2651 \mathrm{a}-\mathrm{d}$ \\
\hline $12 \ldots \ldots \ldots \ldots$ & 3955 a-e & $2639 a-c$ & 3297 a-c & 2729 b-f & $1465 \mathrm{ab}$ & $2097 \mathrm{ab}$ & $2697 \mathrm{a}-\mathrm{d}$ \\
\hline ............ & 2976 c-g & $1503 \mathrm{c}-\mathrm{e}$ & $2239 \mathrm{c}-\mathrm{f}$ & $625 \mathrm{~g}$ & $417 \mathrm{c}$ & $521 \mathrm{~b}$ & $1380 \mathrm{~d}$ \\
\hline $14 \ldots$ & $4604 \mathrm{ab}$ & 3021 a & $3812 \mathrm{ab}$ & $2854 \mathrm{a}-\mathrm{e}$ & $1861 \mathrm{ab}$ & $2358 \mathrm{ab}$ & $3085 \mathrm{ab}$ \\
\hline ........ & 3948 a-e & 1986 a-d & 2967 a-e & $2021 \mathrm{ef}$ & $1535 \mathrm{ab}$ & $1778 \mathrm{ab}$ & $2372 \mathrm{a}-\mathrm{d}$ \\
\hline $16 \ldots \ldots \ldots \ldots$ & $2972 \mathrm{c}-\mathrm{g}$ & $0635 \mathrm{e}$ & 1804 ef & $1604 \mathrm{fg}$ & $1479 a b$ & $1542 \mathrm{ab}$ & $1673 \mathrm{~cd}$ \\
\hline $17 \ldots \ldots \ldots \ldots . . . . . .$. & $4313 \mathrm{a}-\mathrm{d}$ & 2149 a-d & 3231 a-d & $2868 \mathrm{a}-\mathrm{e}$ & $1465 \mathrm{ab}$ & $2167 \mathrm{ab}$ & $2699 \mathrm{a}-\mathrm{d}$ \\
\hline $18 \ldots \ldots \ldots . . . . .$. & $2462 \mathrm{fg}$ & $1056 \mathrm{de}$ & 1759 ef & $2097 \mathrm{ef}$ & $1792 \mathrm{ab}$ & $1944 \mathrm{ab}$ & $1852 \mathrm{~b}-\mathrm{d}$ \\
\hline 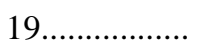 & 4042 a-d & 1726 b-e & 2884 b-e & $3854 \mathrm{ab}$ & $1507 \mathrm{ab}$ & $2680 \mathrm{a}$ & $2782 \mathrm{a}-\mathrm{c}$ \\
\hline 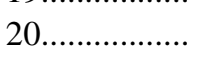 & $5288 \mathrm{a}$ & $3042 \mathrm{a}$ & $4165 \mathrm{a}$ & $3458 \mathrm{a}-\mathrm{c}$ & $1577 \mathrm{ab}$ & $2517 \mathrm{a}$ & 3341 a \\
\hline F (Gen.) & $9,89 *$ & $8,63^{*}$ & $12,91 *$ & $12,39^{*}$ & $5,42 *$ & $2,28^{*}$ & $4,34^{*}$ \\
\hline $\mathrm{F}$ (Anos) & - & - & $339,73^{*}$ & - & - & $51,06^{*}$ & - \\
\hline F (Ensaios) & - & - & - & - & - & - & $65,18^{*}$ \\
\hline$F(G \times A)$ & - & - & 1,27 & - & - & $6,04^{*}$ & - \\
\hline$F(G \times E)$ & - & - & - & - & - & - & $5,00^{*}$ \\
\hline d.m.s. ${ }^{(1)}$ & 1470 & 1292 & 1242 & 1149 & 813 & 1909 & 1369 \\
\hline C.V. (\%) & 14,98 & 25,14 & 19,06 & 16,57 & 19,62 & 18,11 & 18,93 \\
\hline
\end{tabular}

${ }^{(1)}$ Médias seguidas de, pelo menos, uma letra comum não diferem, entre si, pelo teste de Tukey.

* Significativo a $5 \%$. 
Mediante a análise conjunta de ambos os anos, em Monte Alegre do Sul, observa-se que houve efeitos significativos somente para genótipos e para anos (Tabela 17). A interação não significativa genótipos $\mathrm{x}$ anos indica que, apesar da diferença entre os anos, os genótipos mais produtivos, em 1999, também tenderam a ser os mais produtivos no ano seguinte.

O genótipo $20\left(4.165 \mathrm{~kg} \mathrm{ha}^{-1}\right)$ foi o mais produtivo, considerando-se a média dos ensaios de Monte Alegre do Sul, em ambos os anos, diferindo, somente dos genótipos 2, 3, 4, 5, 13, 16, 18 e 19.

A análise conjunta dos dados de produção de grãos em Tatuí, em 1999 e 2000, mostrou efeitos significativos para genótipos, para anos e para a interação genótipos $\mathrm{x}$ anos, indicando comportamento diferencial dos genótipos em relação aos anos.

Comparando-se as médias de produção de grãos obtidas em Tatuí, destacaram-se, em kg ha ${ }^{-1}$, os genótipos 1 (2.635), 2 (2.538), 4 (2.448), 8 (2.729), 19 (2.680) e 20 (2.517), os quais diferiram somente da linhagem 13 (521), a menos produtiva.

Em 1999, a linhagem 1 (3.896 $\left.\mathrm{kg} \mathrm{ha}^{-1}\right)$ foi a mais produtiva, não diferindo, porém, em kg ha-1 dos genótipos 2 (3.055), 4 (2.938), 7 (3.048), 8 (3.271), 9 (2.917), 14 (2.854), 17 (2.868), 19 (3.854) e 20 (3.458). Em 2000, destacou-se a linhagem 8 $\left(2.187 \mathrm{~kg} \mathrm{ha}^{-1}\right)$ como a mais produtiva, diferindo, porém, apenas da linhagem 13 (417 $\left.\mathrm{kg} \mathrm{ha}^{-1}\right)$ a menos produtiva.

Na Tabela 18, encontram-se os dados médios de altura da planta dos genótipos do Ensaio de Linhagens Diaplóides de Trigo II, em Monte Alegre do Sul e Tatuí, em 1999 e 2000.

A análise conjunta desses quatro ensaios mostrou efeitos significativos para genótipos, para ensaios e para a interação genótipos x ensaios. A linhagem diaplóide 13 $(61 \mathrm{~cm})$ foi a mais baixa, não diferindo das linhagens $6(67 \mathrm{~cm}), 7(68 \mathrm{~cm})$ e $10(65 \mathrm{~cm})$. Os genótipos $3(116 \mathrm{~cm})$ e $18(119 \mathrm{~cm})$ foram os mais altos, não diferindo somente da linhagem $2(108 \mathrm{~cm})$. Apesar da interação significativa genótipos x ensaios, a linhagem 13 mostrou-se uma das mais baixas em todos os ensaios. 
Tabela 18. Altura da planta dos genótipos avaliados no Ensaio de Linhagens Diaplóides de Trigo II, nas Estações Experimentais de Agronomia de Monte Alegre do Sul e Tatuí, em 1999 e 2000.

\begin{tabular}{|c|c|c|c|c|c|c|c|}
\hline \multirow{3}{*}{ Genótipos } & \multicolumn{7}{|c|}{ Altura da planta } \\
\hline & \multicolumn{3}{|c|}{ Monte Alegre do Sul } & \multicolumn{3}{|c|}{ Tatuí } & \multirow{2}{*}{$\begin{array}{c}\text { Média } \\
\text { geral }\end{array}$} \\
\hline & 1999 & 2000 & Média & 1999 & 2000 & Média & \\
\hline $1 \ldots \ldots \ldots \ldots$ & $96 \mathrm{~cd}$ & $95 \mathrm{c}$ & $96 \mathrm{c}$ & $96 \mathrm{~cd}$ & $69 \mathrm{~b}-\mathrm{d}$ & $82 \mathrm{c}-\mathrm{e}$ & $89 \mathrm{c}$ \\
\hline $2 \ldots \ldots \ldots \ldots$ & $106 \mathrm{~b}$ & $118 \mathrm{ab}$ & $112 \mathrm{ab}$ & $113 a b$ & $94 \mathrm{a}$ & $104 \mathrm{ab}$ & $108 \mathrm{ab}$ \\
\hline $3 \ldots \ldots \ldots \ldots \ldots$ & $119 \mathrm{a}$ & $119 \mathrm{ab}$ & $119 \mathrm{a}$ & $123 \mathrm{a}$ & $106 \mathrm{a}$ & $114 \mathrm{a}$ & $116 \mathrm{a}$ \\
\hline $4 \ldots \ldots \ldots \ldots$ & $103 \mathrm{~b}-\mathrm{d}$ & $110 \mathrm{ab}$ & $107 \mathrm{~b}$ & $104 \mathrm{bc}$ & $94 \mathrm{a}$ & 99 a-c & $103 \mathrm{~b}$ \\
\hline $5 \ldots \ldots \ldots \ldots \ldots \ldots$ & 69 ef & $71 \mathrm{de}$ & 70 de & $76 \mathrm{fg}$ & $76 \mathrm{~b}$ & $76 \mathrm{~d}-\mathrm{f}$ & $73 \mathrm{fg}$ \\
\hline $6 \ldots \ldots \ldots \ldots \ldots$ & 68 ef & $69 \mathrm{de}$ & $68 \mathrm{e}$ & $71 \mathrm{gh}$ & $61 \mathrm{c}-\mathrm{f}$ & $66 \mathrm{ef}$ & $67 \mathrm{gh}$ \\
\hline 7................. & $71 \mathrm{ef}$ & $75 \mathrm{de}$ & $73 \mathrm{de}$ & $70 \mathrm{gh}$ & $57 \mathrm{~d}-\mathrm{f}$ & $63 \mathrm{ef}$ & $68 \mathrm{gh}$ \\
\hline $8 \ldots \ldots \ldots \ldots \ldots$ & $91 \mathrm{~d}$ & $93 \mathrm{c}$ & $92 \mathrm{c}$ & $90 \mathrm{~d}$ & $69 \mathrm{~b}-\mathrm{d}$ & 79 c-e & $85 \mathrm{~cd}$ \\
\hline $9 \ldots \ldots \ldots \ldots \ldots$ & $76 \mathrm{e}$ & $79 \mathrm{~d}$ & $77 \mathrm{~d}$ & 83 ef & $57 \mathrm{~d}-\mathrm{f}$ & 70 ef & 74 d-g \\
\hline $10 \ldots \ldots \ldots \ldots \ldots$ & $67 \mathrm{f}$ & $70 \mathrm{de}$ & $68 \mathrm{e}$ & $69 \mathrm{gh}$ & 54 ef & $62 \mathrm{ef}$ & $65 \mathrm{gh}$ \\
\hline $11 \ldots \ldots \ldots \ldots \ldots$ & $96 \mathrm{~cd}$ & $95 \mathrm{c}$ & $96 \mathrm{c}$ & $93 \mathrm{de}$ & $72 \mathrm{bc}$ & $82 \mathrm{c}-\mathrm{e}$ & $89 \mathrm{c}$ \\
\hline $12 \ldots \ldots \ldots \ldots \ldots$ & $87 \mathrm{~d}$ & $91 \mathrm{c}$ & $89 \mathrm{c}$ & $87 \mathrm{~d}$ & $66 \mathrm{~b}-\mathrm{e}$ & 76 d-f & $83 \mathrm{c}-\mathrm{f}$ \\
\hline $13 \ldots \ldots \ldots \ldots \ldots$ & $62 \mathrm{f}$ & $68 \mathrm{e}$ & $65 \mathrm{e}$ & $65 \mathrm{~h}$ & $50 \mathrm{f}$ & $58 \mathrm{f}$ & $61 \mathrm{~h}$ \\
\hline $14 \ldots \ldots \ldots \ldots \ldots$ & $92 \mathrm{~d}$ & $92 \mathrm{c}$ & $92 \mathrm{c}$ & $93 \mathrm{de}$ & $68 \mathrm{~b}-\mathrm{d}$ & $80 \mathrm{c}-\mathrm{e}$ & $86 \mathrm{c}$ \\
\hline $15 \ldots \ldots \ldots \ldots$ & $90 \mathrm{~d}$ & $91 \mathrm{c}$ & $90 \mathrm{c}$ & $93 \mathrm{de}$ & 64 b-e & 78 d-f & $84 \mathrm{c}-\mathrm{f}$ \\
\hline $16 \ldots \ldots \ldots \ldots$ & $96 \mathrm{~cd}$ & $96 \mathrm{c}$ & $96 \mathrm{c}$ & $96 \mathrm{~cd}$ & $74 \mathrm{~b}$ & $85 b-d$ & $90 \mathrm{c}$ \\
\hline $17 \ldots \ldots \ldots \ldots \ldots$ & $89 d$ & $92 \mathrm{c}$ & $90 \mathrm{c}$ & $87 \mathrm{~d}$ & 64 b-e & $75 \mathrm{~d}-\mathrm{f}$ & $83 \mathrm{c}-\mathrm{f}$ \\
\hline $18 \ldots \ldots \ldots \ldots \ldots \ldots$ & $124 \mathrm{a}$ & $127 \mathrm{a}$ & $125 \mathrm{a}$ & $123 \mathrm{a}$ & $101 \mathrm{a}$ & $112 \mathrm{a}$ & $119 \mathrm{a}$ \\
\hline $19 \ldots \ldots \ldots \ldots \ldots$ & $95 \mathrm{~cd}$ & $97 \mathrm{c}$ & $96 \mathrm{c}$ & $92 \mathrm{~d}$ & $65 \mathrm{~b}-\mathrm{e}$ & 78 d-f & $87 \mathrm{c}$ \\
\hline $20 \ldots \ldots \ldots \ldots \ldots \ldots$ & $90 \mathrm{~d}$ & $93 \mathrm{c}$ & $92 \mathrm{c}$ & $92 \mathrm{~d}$ & $66 \mathrm{~b}-\mathrm{e}$ & 79 c-e & $85 \mathrm{~cd}$ \\
\hline F (Gen.) & $75,77 *$ & $61,24^{*}$ & $120,93 *$ & $66,45^{*}$ & $38,35^{*}$ & $18,17 *$ & $51,85^{*}$ \\
\hline F (Anos) & - & - & $16,32 *$ & - & - & $142,52 *$ & - \\
\hline F (Ensaios) & - & - & - & - & - & - & $96,37^{*}$ \\
\hline$F(G \times A)$ & - & - & 0,99 & - & - & $4,70^{*}$ & - \\
\hline$F(G \times E)$ & - & - & - & - & - & - & $3,80 *$ \\
\hline d.m.s. ${ }^{(1)}$ & 10 & 11 & 9 & 11 & 13 & 21 & 12 \\
\hline C.V. $(\%)$ & 4,33 & 4,72 & 4,80 & 4,45 & 7,05 & 5,89 & 5,32 \\
\hline
\end{tabular}

${ }^{(1)}$ Médias seguidas de, pelo menos, uma letra comum não diferem, entre si, pelo teste de Tukey.

* Significativo a $5 \%$. 
A análise da variância dos dados nos ensaios da Estação Experimental de Monte Alegre do Sul, em 1999 e 2000, revelou efeitos significativos apenas para genótipos e para anos. Os genótipos $6(68 \mathrm{~cm}), 10(68 \mathrm{~cm})$ e $13(65 \mathrm{~cm})$ foram os mais baixos, não diferindo somente das linhagens 5 e 7 , com 70 e $73 \mathrm{~cm}$ respectivamente. Os genótipos 3 e 18 foram os mais altos, com 119 e $125 \mathrm{~cm}$ respectivamente, não diferindo da linhagem $2(112 \mathrm{~cm})$, quando analisados em conjunto os ensaios de Monte Alegre do Sul.

Nos ensaios de Tatuí, quando tomados em conjunto, verificaram-se efeitos significativos para genótipos, para anos e para a interação genótipos x anos. A linhagem $13(58 \mathrm{~cm})$, com as plantas mais baixas, não diferiu dos genótipos 5, 6, 7, 9, 10, 12, 15, 17 e 19, cuja altura da planta variou de 62 a $78 \mathrm{~cm}$; já os genótipos mais altos, 3 $(114 \mathrm{~cm})$ e $18(112 \mathrm{~cm})$, não diferiram somente das linhagens $2(104 \mathrm{~cm})$ e $4(99 \mathrm{~cm})$.

Em 1999, destacou-se a linhagem $13(65 \mathrm{~cm})$ com as plantas mais baixas, não diferindo, apenas, das linhagens 6,7 e 10 (71, 70 e $69 \mathrm{~cm}$ respectivamente). As linhagens 3 e 18 (ambas com $123 \mathrm{~cm}$ ) foram as mais altas, não diferindo, porém, apenas da linhagem $2(113 \mathrm{~cm})$. Em 2000, a linhagem $13(50 \mathrm{~cm})$, que não diferiu das linhagens $6,7,9$ e $10(61,57,57$ e $54 \mathrm{~cm}$ respectivamente) apresentou as plantas mais baixas, e os genótipos $2(94 \mathrm{~cm}), 3(106 \mathrm{~cm}), 4(94 \mathrm{~cm})$ e $18(101 \mathrm{~cm})$, as mais altas.

As correlações entre produção de grãos e altura da planta, considerando-se as médias obtidas nos ensaios de Monte Alegre do Sul e Tatuí, em ambos os anos, não apresentaram efeitos significativos; isso indicou que os genótipos mais altos não tenderam a ser os mais produtivos, contrariando trabalhos de Camargo \& Ramos (1989), nos quais se encontraram valores positivos e significativos em estudos de herdabilidade e associações entre características agronômicas em trigo.

Na Tabela 19, acham-se os dados de ciclos da emergência ao florescimento e da emergência à maturação dos genótipos do Ensaio de Linhagens Diaplóides de Trigo II, em Monte Alegre do Sul, em 1999 e 2000, e em Tatuí, em 2000.

As análises conjuntas dos dados do ciclo das plantas da emergência ao florescimento dos ensaios de Monte Alegre do Sul, em 1999 e 2000, e de Tatuí, em 2000, mostraram efeitos significativos para genótipos, para ensaios e para a interação 
Tabela 19. Ciclos da emergência ao florescimento e da emergência à maturação, em dias, dos genótipos avaliados no Ensaio de Linhagens Diaplóides de Trigo II, nas Estações Experimentais de Agronomia de Monte Alegre do Sul, em 1999 e 2000, e Tatuí em 2000.

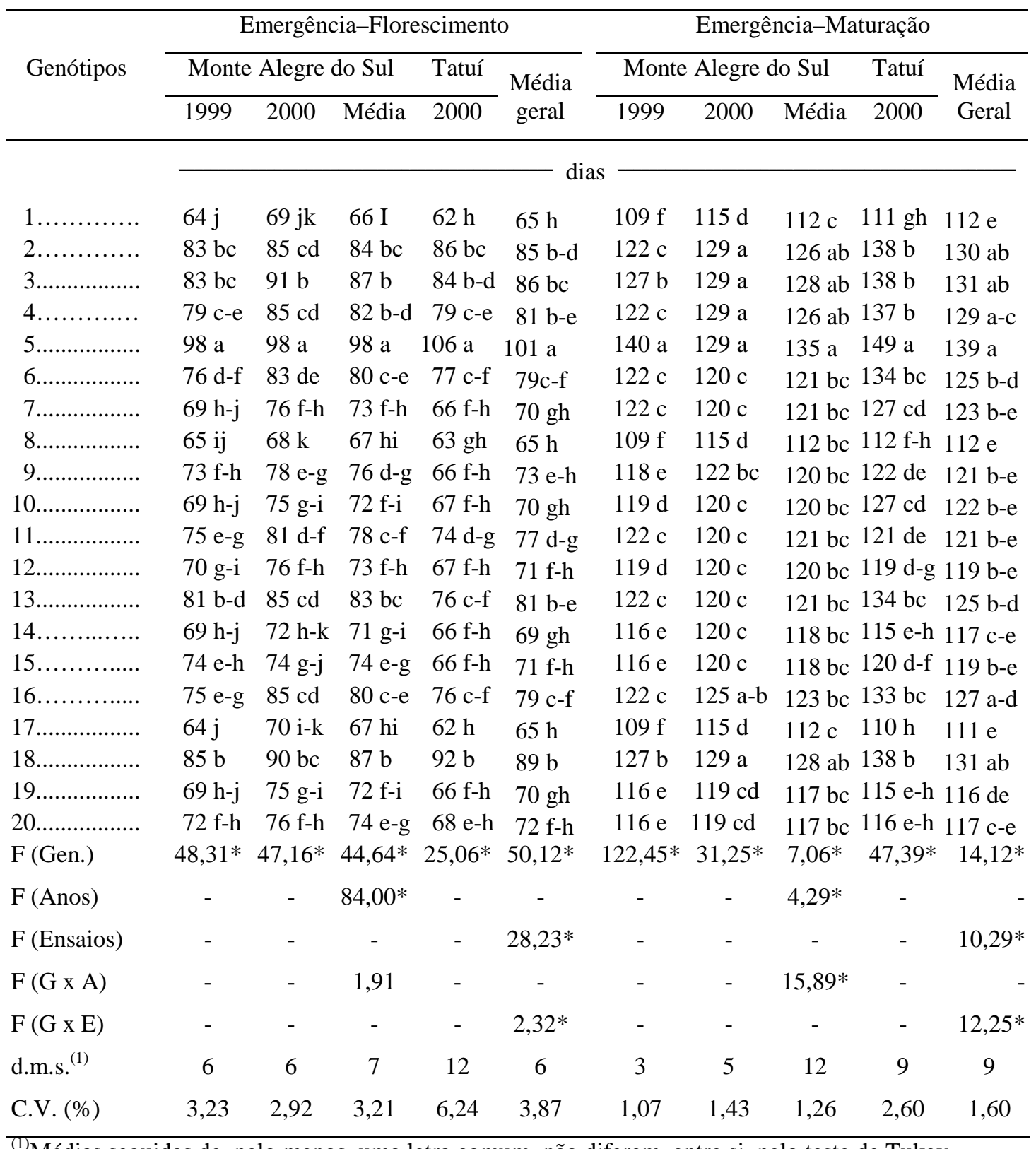

${ }^{(1)}$ Médias seguidas de, pelo menos, uma letra comum não diferem, entre si, pelo teste de Tukey.

*Significativo a $5 \%$. 
genótipos $\mathrm{x}$ ensaios, indicando que os genótipos tiveram comportamento diferencial em relação aos ensaios. Apesar da interação significativa genótipos x ensaios, a linhagem 5 apresentou o maior número de dias para florescer nos três ensaios.

Comparando-se as médias dos três ensaios, destacaram-se as linhagens 1, 8 e 17 (65 dias), apresentando o ciclo mais precoce da emergência ao florescimento, não diferindo, porém, dos genótipos 7, 9, 10, 12, 14, 15, 19 e 20.

Nos ensaios da Estação Experimental de Agronomia de Monte Alegre do Sul, em 1999 e 2000, verificaram-se efeitos significativos somente para genótipos e para anos. Na média dos dois anos, a linhagem 1 (66 dias) foi a mais precoce para florescer, não diferindo somente dos genótipos 8 (67 dias), 10 (72 dias), 14 (71 dias), 17 (67 dias) e 19 (72 dias). A linhagem 5 (98 dias) foi a mais tardia.

Em Tatuí, em 2000, as mais precoces para o florescimento foram as linhagens 1 e 17 (ambas com 62 dias), diferindo da 2, 3, 4, 5, 6, 11, 13, 16 e 18, com um ciclo da emergência ao florescimento de 74 a 106 dias.

A análise conjunta dos dados de ciclo da emergência à maturação, quando considerados em conjunto os ensaios de Monte Alegre do Sul, em ambos os anos, e Tatuí, em 2000, mostrou efeitos significativos para genótipos, para anos e para a interação genótipos $\mathrm{x}$ ensaios. Apesar de a interação genótipos $\mathrm{x}$ ensaios ter sido significativa, as linhagens 5 e 17 destacaram-se por apresentar, respectivamente, o ciclo mais longo e o mais curto, independentemente do ensaio em que foram avaliadas.

Na média dos ensaios de Monte Alegre do Sul, destacaram-se como as mais precoces para maturar as linhagens 1 e 17 (cada uma com 112 dias), as quais diferiram dos genótipos 2, 3, 4, 5 e 18, com um ciclo entre 126 e 135 dias, considerados os mais tardios.

Em 1999, destacaram-se as linhagens 1, 8 e 17 (cada qual com 109 dias) como as mais precoces para maturar. Em 2000, as mais precoces para maturar foram as linhagens 1, 8 e 17 (as três com 115 dias), não diferindo, porém, dos genótipos 19 e 20 (ambos com 119 dias).

Em Tatuí, a linhagem 17 (110 dias) apresentou o ciclo mais precoce da emergência à maturação, não diferindo, porém, dos genótipos 1 (111 dias), 8 (112 dias), 14 (115 dias), 19 (115 dias) e 20 (116 dias). 
As porcentagens médias de acamamento dos genótipos do Ensaio de Linhagens Diaplóides de Trigo II encontram-se na Tabela 20. Observa-se que os genótipos 5, 10 e 13 mostraram-se resistentes ao acamamento. Destacaram-se, também, pela baixa ocorrência de plantas acamadas, os genótipos 6, 7, 12 e 20 com acamamento inferior a $10 \%$, considerando-se em conjunto a média dos quatro ensaios.

A correlação entre altura da planta e porcentagem de acamamento, levando-se em conta as médias obtidas nos quatro Ensaios de Linhagens diaplóides de Trigo II, foi significativa e positiva $(\mathrm{r}=0,79 *)$, indicando uma tendência de os genótipos mais altos apresentarem as maiores porcentagens de acamamento. Esses resultados concordam com Camargo et al. (1991a), avaliando genótipos oriundos de populações híbridas introduzidas de Oregon (EUA), no Estado de São Paulo.

Esse fato poderia explicar a correlação não significativa entre produção de grãos e altura da planta, uma vez que as mais altas foram mais sensíveis ao acamamento. Este apresentaria restrições à translocação de fotoassimilados e água, em vista do estrangulamento do colmo e, em conseqüência, causaria decréscimos na produção (Laude \& Pauli, 1956).

Nas Tabelas 21, 22 e 23, encontram-se, respectivamente, os dados de graus médios de infecção de ferrugem-da-folha, mancha-da-folha e oídio respectivamente, dos genótipos avaliados em Monte Alegre do Sul e Tatuí, nos dois anos.

Os dados de ferrugem-da-folha (Tabela 21) mostram maior porcentagem de infecção em Tatuí, possivelmente por ser uma região tradicionalmente produtora de trigo e, portanto, sujeita a maior quantidade de esporos migrando de uma área para outra, enquanto em Monte Alegre do Sul o trigo é plantado apenas ao nível experimental e em pequena área.

Assim, a linhagem 3, por possuir, nas folhas superiores, uma porcentagem máxima de área foliar infectada igual a 5 , foi considerada resistente ao agente causal da ferrugem-da-folha, as demais com uma infecção máxima de 6 a 20\%, foram consideradas moderadamente resistentes, com exceção dos genótipos 11, 14, 15, 17 e 20, com um grau máximo de infecção de 28 a 33\%, foram consideradas suscetíveis e, a 13 (60\%), altamente suscetível. 
Tabela 20. Porcentagem de acamamento dos genótipos avaliados no Ensaio de Linhagens Diaplóides de Trigo II, nas Estações Experimentais de Agronomia de Monte Alegre do Sul e Tatuí em 1999 e 2000.

\begin{tabular}{|c|c|c|c|c|c|c|c|}
\hline \multirow{3}{*}{ Genótipos } & \multicolumn{7}{|c|}{ Acamamento } \\
\hline & \multicolumn{3}{|c|}{ Monte Alegre do Sul } & \multicolumn{3}{|c|}{ Tatuí } & \multirow{2}{*}{$\begin{array}{l}\text { Média } \\
\text { geral }\end{array}$} \\
\hline & 1999 & 2000 & Média & 1999 & 2000 & Média & \\
\hline & & & & $\%$ & & & ـ \\
\hline $1 \ldots \ldots \ldots \ldots$ & 25 & 80 & 53 & 30 & 20 & 25 & 39 \\
\hline 2 . & 20 & 75 & 48 & 20 & 10 & 15 & 31 \\
\hline 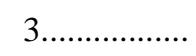 & 60 & 80 & 70 & 30 & 10 & 20 & 45 \\
\hline $4 \ldots \ldots \ldots \ldots$ & 5 & 65 & 35 & 0 & 5 & 3 & 19 \\
\hline $5 \ldots \ldots \ldots \ldots \ldots$ & 0 & 0 & 0 & 0 & 0 & 0 & 0 \\
\hline $6 \ldots \ldots \ldots \ldots \ldots . . .$. & 5 & 20 & 13 & 10 & 0 & 5 & 9 \\
\hline $7 \ldots \ldots$. & 0 & 15 & 8 & 0 & 0 & 0 & 4 \\
\hline 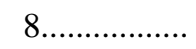 & 5 & 70 & 38 & 0 & 0 & 0 & 19 \\
\hline $9 \ldots \ldots$ & 0 & 60 & 30 & 0 & 10 & 5 & 18 \\
\hline $10 \ldots \ldots \ldots \ldots \ldots . . .$. & 0 & 0 & 0 & 0 & 0 & 0 & 0 \\
\hline $11 \ldots \ldots \ldots \ldots . . .$. & 5 & 85 & 45 & 0 & 0 & 0 & 23 \\
\hline $12 \ldots$ & 0 & 35 & 18 & 0 & 0 & 0 & 9 \\
\hline $13 \ldots \ldots \ldots$ & 0 & 0 & 0 & 0 & 0 & 0 & 0 \\
\hline $14 \ldots \ldots \ldots \ldots$ & 5 & 80 & 43 & 0 & 0 & 0 & 21 \\
\hline $15 \ldots \ldots \ldots \ldots$ & 20 & 70 & 45 & 0 & 0 & 0 & 23 \\
\hline $16 \ldots \ldots \ldots \ldots$ & 50 & 95 & 73 & 5 & 0 & 3 & 38 \\
\hline $17 \ldots \ldots$ & 0 & 55 & 28 & 0 & 5 & 3 & 15 \\
\hline $18 \ldots \ldots \ldots$ & 30 & 75 & 53 & 20 & 0 & 10 & 31 \\
\hline $19 \ldots \ldots \ldots$ & 15 & 85 & 50 & 0 & 0 & 0 & 25 \\
\hline $20 \ldots \ldots \ldots \ldots . . . . . . . .$. & 0 & 25 & 13 & 0 & 0 & 0 & 6 \\
\hline
\end{tabular}


Tabela 21. Porcentagem de área foliar infectada pelo agente causal da ferrugem-da-folha ${ }^{(1)}$ dos genótipos avaliados no Ensaio de Linhagens Diaplóides de Trigo II, nas Estações Experimentais de Agronomia de Monte Alegre do Sul e Tatuí em 1999 e 2000.

\begin{tabular}{|c|c|c|c|c|}
\hline \multirow{3}{*}{ Genótipos } & \multicolumn{4}{|c|}{ Ferrugem-da-folha } \\
\hline & \multicolumn{2}{|c|}{ Monte Alegre do Sul } & \multicolumn{2}{|c|}{ Tatuí } \\
\hline & $1999^{(2)}$ & $2000^{(3)}$ & $1999^{(2)}$ & $2000^{(2)}$ \\
\hline & & & & \\
\hline $1 \ldots \ldots \ldots \ldots \ldots$ & 0 & 0 & $10 \mathrm{~S}$ & $30 \mathrm{~S}$ \\
\hline $2 \ldots \ldots \ldots \ldots \ldots$ & 0 & 0 & $9 \mathrm{~S}$ & $10 \mathrm{~S}$ \\
\hline $3 \ldots \ldots \ldots \ldots \ldots$ & 0 & $5 S$ & $4 \mathrm{~S}$ & 0 \\
\hline $4 \ldots \ldots \ldots \ldots \ldots$ & 0 & 0 & $6 \mathrm{~S}$ & $\mathrm{tS}$ \\
\hline $5 \ldots \ldots \ldots \ldots \ldots \ldots$ & 0 & 0 & $8 \mathrm{~S}$ & 0 \\
\hline $6 \ldots \ldots \ldots \ldots \ldots$ & $5 \mathrm{~S}$ & 0 & $18 \mathrm{~S}$ & $10 \mathrm{~S}$ \\
\hline $7 \ldots \ldots \ldots \ldots \ldots$ & 0 & $3 \mathrm{~S}$ & $13 \mathrm{~S}$ & $20 \mathrm{~S}$ \\
\hline $8 \ldots \ldots \ldots \ldots \ldots$ & 0 & $3 \mathrm{~S}$ & $9 \mathrm{~S}$ & $5 \mathrm{~S}$ \\
\hline $9 \ldots \ldots \ldots \ldots \ldots$ & 0 & 0 & $13 \mathrm{~S}$ & $20 \mathrm{~S}$ \\
\hline $10 \ldots \ldots \ldots \ldots$ & 0 & $3 \mathrm{~S}$ & $13 \mathrm{~S}$ & $10 \mathrm{~S}$ \\
\hline $11 \ldots \ldots \ldots \ldots$ & 0 & 0 & $30 \mathrm{~S}$ & $30 \mathrm{~S}$ \\
\hline $12 \ldots \ldots \ldots \ldots \ldots \ldots$ & 0 & 0 & $18 \mathrm{~S}$ & $5 \mathrm{~S}$ \\
\hline $13 \ldots \ldots \ldots \ldots \ldots$ & 0 & $3 \mathrm{~S}$ & $60 \mathrm{~S}$ & $50 \mathrm{~S}$ \\
\hline $14 \ldots \ldots \ldots \ldots \ldots$ & $3 \mathrm{~S}$ & $\mathrm{tS}$ & $33 \mathrm{~S}$ & $10 \mathrm{~S}$ \\
\hline $15 \ldots \ldots \ldots \ldots \ldots$ & $4 \mathrm{~S}$ & $\mathrm{tS}$ & $40 \mathrm{~S}$ & $40 \mathrm{~S}$ \\
\hline $16 \ldots \ldots \ldots \ldots \ldots$ & 0 & $\mathrm{tS}$ & $6 \mathrm{~S}$ & $5 \mathrm{~S}$ \\
\hline $17 \ldots \ldots \ldots \ldots \ldots \ldots$ & 0 & 0 & $33 \mathrm{~S}$ & $10 \mathrm{~S}$ \\
\hline $18 \ldots \ldots \ldots \ldots \ldots$ & 0 & $\mathrm{t} S$ & $13 \mathrm{~S}$ & $\mathrm{tS}$ \\
\hline $19 \ldots \ldots$ & 0 & 0 & $18 \mathrm{~S}$ & $10 \mathrm{~S}$ \\
\hline $20 \ldots \ldots \ldots \ldots \ldots \ldots$ & $8 \mathrm{~S}$ & $\mathrm{tS}$ & $28 \mathrm{~S}$ & $20 \mathrm{~S}$ \\
\hline
\end{tabular}

${ }^{(1)}$ Avaliação de ferrugem-da-folha segundo Schramm et. al. (1974): $0=$ imune; 1 a 5\% de área infectada $=$ resistente; 6 a $25 \%=$ moderadamente resistente; 26 a $50 \%=$ suscetível, e 51 a $99 \%=$ altamente suscetível; $\mathrm{t}=$ traço (apenas algumas pústulas); $\mathrm{S}=$ reação de suscetibilidade; $\mathrm{MS}=$ reação de moderada suscetibilidade.

(2) Avaliação realizada nas folhas superiores.

(3) Avaliações realizadas nas folhas bandeiras. 
Tabela 22. Porcentagem de área foliar infectada pelo agente causal da mancha-da-folha ${ }^{(1)}$ dos genótipos avaliados no Ensaio de Linhagens Diaplóides de Trigo II, nas Estações Experimentais de Agronomia de Monte Alegre do Sul e Tatuí em 1999 e 2000.

\begin{tabular}{|c|c|c|c|c|}
\hline \multirow{3}{*}{ Genótipos } & \multicolumn{4}{|c|}{ Mancha-da-folha } \\
\hline & \multicolumn{2}{|c|}{ Monte Alegre do Sul } & \multicolumn{2}{|c|}{ Tatuí } \\
\hline & $1999^{(2)}$ & $2000^{(3)}$ & $1999^{(2)}$ & $2000^{(2)}$ \\
\hline & & 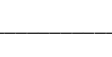 & 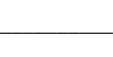 & - \\
\hline $1 \ldots \ldots \ldots \ldots \ldots$ & 28 & 13 & 20 & 40 \\
\hline $2 \ldots \ldots \ldots \ldots \ldots$ & 20 & 20 & 20 & 30 \\
\hline 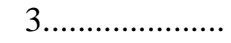 & 23 & 15 & 20 & 20 \\
\hline $4 \ldots$ & 28 & 18 & 20 & 20 \\
\hline $5 \ldots \ldots \ldots \ldots \ldots \ldots$ & 15 & 15 & 20 & 20 \\
\hline 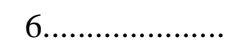 & 18 & 13 & 23 & 60 \\
\hline 7.......................... & 30 & 10 & 20 & 30 \\
\hline 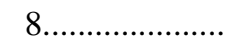 & 30 & 16 & 25 & 70 \\
\hline 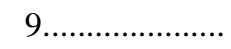 & 28 & 15 & 20 & 40 \\
\hline 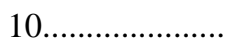 & 28 & 18 & 25 & 60 \\
\hline $11 \ldots \ldots \ldots \ldots$ & 20 & 16 & 23 & 70 \\
\hline $12 \ldots \ldots \ldots$ & 35 & 15 & 23 & 30 \\
\hline $13 \ldots \ldots \ldots \ldots \ldots \ldots$ & 10 & 16 & 33 & 90 \\
\hline $14 \ldots \ldots \ldots \ldots \ldots$ & 30 & 13 & 40 & 80 \\
\hline $15 \ldots \ldots \ldots \ldots \ldots$ & 18 & 16 & 38 & 60 \\
\hline $16 \ldots \ldots \ldots \ldots \ldots$ & 28 & 10 & 20 & 40 \\
\hline 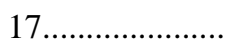 & 38 & 25 & 38 & 60 \\
\hline $18 \ldots \ldots \ldots \ldots \ldots \ldots$ & 18 & 19 & 20 & 40 \\
\hline $19 \ldots \ldots \ldots \ldots \ldots$ & 28 & 14 & 23 & 40 \\
\hline $20 \ldots \ldots \ldots \ldots \ldots$ & 15 & 15 & 28 & 40 \\
\hline
\end{tabular}

${ }^{(1)}$ Avaliação de mancha-da-folha segundo Mehta (1978): $0=$ imune; 1 a 5\% de área infectada = resistente; 6 a $25 \%=$ moderadamente resistente; 26 a $50 \%=$ suscetível, e 51 a $99 \%=$ altamente suscetível.

(2) Avaliação realizada nas folhas superiores.

(3) Avaliações realizadas nas folhas bandeiras. 
Tabela 23. Porcentagem de área foliar infectada pelo agente causal do oídio $^{(1)}$ dos genótipos avaliados no Ensaio de Linhagens Diaplóides de Trigo II, nas Estações Experimentais de Agronomia de Monte Alegre do Sul e Tatuí em 1999 e 2000.

\begin{tabular}{|c|c|c|c|c|}
\hline \multirow{3}{*}{ Genótipos } & \multicolumn{4}{|c|}{ Oídio } \\
\hline & \multicolumn{2}{|c|}{ Monte Alegre do Sul } & \multicolumn{2}{|c|}{ Tatuí } \\
\hline & $1999^{(2)}$ & $2000^{(3)}$ & $1999^{(2)}$ & $2000^{(2)}$ \\
\hline & & & & - \\
\hline $1 \ldots \ldots \ldots \ldots \ldots$ & 0 & 0 & 0 & 0 \\
\hline $2 \ldots \ldots \ldots \ldots \ldots$ & 0 & 0 & 0 & 0 \\
\hline 3....................... & 0 & 0 & 0 & 0 \\
\hline ........ & 0 & 0 & 0 & 0 \\
\hline $5 \ldots \ldots \ldots \ldots \ldots \ldots$ & 0 & 0 & 0 & 0 \\
\hline 6....................... & 0 & 0 & 0 & 0 \\
\hline $7 \ldots$. & 0 & 0 & 0 & 0 \\
\hline 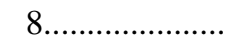 & $\mathrm{tS}$ & 0 & 10 & 0 \\
\hline $9 \ldots \ldots \ldots \ldots \ldots \ldots$ & 0 & 0 & 0 & 0 \\
\hline $10 \ldots \ldots \ldots \ldots \ldots \ldots$ & 0 & 0 & 4 & 0 \\
\hline $11 \ldots \ldots \ldots \ldots \ldots \ldots$ & 0 & 0 & 0 & 0 \\
\hline $12 \ldots \ldots \ldots \ldots \ldots \ldots$ & 0 & 0 & 0 & 0 \\
\hline $13 \ldots \ldots \ldots \ldots \ldots \ldots$ & 0 & 0 & 0 & 0 \\
\hline $14 \ldots \ldots \ldots \ldots \ldots$ & 0 & 0 & 0 & 0 \\
\hline $15 \ldots \ldots \ldots \ldots \ldots$ & 0 & 0 & 0 & 0 \\
\hline $16 \ldots \ldots \ldots \ldots \ldots$ & 0 & 0 & 0 & 0 \\
\hline 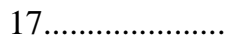 & 0 & 0 & 0 & 0 \\
\hline 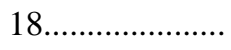 & 0 & 0 & 0 & 0 \\
\hline $19 \ldots \ldots \ldots \ldots \ldots \ldots \ldots$ & 0 & 0 & 0 & 0 \\
\hline $20 \ldots \ldots$ & 0 & 0 & 0 & 0 \\
\hline
\end{tabular}

${ }^{(1)}$ Avaliação de oídio segundo Mehta (1978): 0 = imune; 1 a 5\% de área infectada = resistente; 6 a $25 \%$ = moderadamente resistente; 26 a 50\% = suscetível, e 51 a $99 \%$ = altamente suscetível; $\mathrm{t}$ $=$ traço.

(2) Avaliação realizada nas folhas superiores.

(3) Avaliações realizadas nas folhas bandeiras. 
As avaliações realizadas considerando-se a folha bandeira, no ensaio de Monte Alegre do Sul, em 2000, mostraram baixa porcentagem de área foliar infectada, variando de 0 a 5\%. De acordo com essa avaliação, todos os genótipos seriam resistentes, segundo a escala de Mehta (1978), esse fato vem comprovar a necessidade de avaliar as folhas superiores, uma vez que a maioria das doenças começa a atingir as plantas a partir das inferiores.

As porcentagens de área foliar infectada por mancha-da-folha (Tabela 22) não mostram grandes diferenças entre Monte Alegre do Sul e Tatuí, em 1999, cujas avaliações foram feitas nas folhas superiores, isso porque uma das principais fontes de contaminação para essa doença está presente nos restos vegetais deixados de um ano para o outro, estando presentes nos dois locais.

Os genótipos 3 e 5, com um grau máximo de infecção, nas folhas superiores, de 23 e 20\% respectivamente, foram considerados moderadamente resistentes à manchada-folha, os genótipos $1,2,4,7,9,12,16,18,19$ e 20, com um grau máximo de infecção entre 28 e 40\%, suscetíveis e, os demais, com um grau máximo de infecção superior $60 \%$, em pelo menos um dos locais, altamente suscetíveis (Tabela 22). As avaliações na folha bandeira, em Monte Alegre do Sul, em 2000, oscilaram de 10 a 25\% de área foliar infectada, sendo todos os genótipos considerados moderadamente resistentes.

Os dados de avaliação para a infecção de oídio (Tabela 23) mostraram que todos os genótipos foram considerados imunes, exceto as linhagens 8 e 10, com um grau máximo de infecção de 10 e $4 \%$ respectivamente, as quais foram consideradas resistentes. Esses dados, porém, devem ser observados com cautela, uma vez que as condições ambientais nos dois anos foram desfavoráveis ao desenvolvimento da doença.

A linhagem 3 destacou-se por apresentar, ao mesmo tempo, resistência ao agente causal da ferrugem-da-folha, moderada resistência ao da mancha-da-folha e imunidade ao do oídio. Destacou-se, também, a linhagem 5, revelando ao mesmo tempo, moderada resistência aos agentes causais da ferrugem-da-folha e mancha-da-folha e imunidade ao oídio.

As médias dos comprimentos da espiga dos genótipos no Ensaio de Linhagens Diaplóides de Trigo II, em Monte Alegre do Sul e Tatuí, encontram-se na Tabela 24. 
A análise da variância conjunta dos quatro Ensaios II mostrou efeitos significativos para genótipos, para ensaios e para a interação genótipos x ensaios.

Destacaram-se, na média dos quatro ensaios, as linhagens 3, 5, 6, 9, 10 e 18, com o comprimento da espiga entre 10,1 e 10,4 cm, não diferindo, porém, das linhagens $2,4,7,8,11$ e 17 .

Nos ensaios em Monte Alegre do Sul, nos dois anos, a análise dos dados exibiu efeitos significativos apenas para genótipos e para anos.

Na comparação das médias de comprimento da espiga, considerando-se em conjunto os ensaios de Monte Alegre do Sul, em 1999 e 2000, destacou-se a linhagem 9 $(10,5 \mathrm{~cm})$ com as espigas mais compridas, diferindo dos genótipos 1, 12, 13, 14, 15, 16, 19 e 20 , com o comprimento da espiga de 7,8 a $9,3 \mathrm{~cm}$.

A análise dos ensaios instalados em Tatuí, quando tomados em conjunto, mostrou efeitos significativos para genótipos, para anos e para a interação genótipos $\mathrm{x}$ anos, indicando que os genótipos apresentaram comportamento diferencial em relação aos anos em sua avaliação. Destacaram-se os de número $3(10,4 \mathrm{~cm}), 5(10,3 \mathrm{~cm}), 6$ $(10,6 \mathrm{~cm}), 10(10,3 \mathrm{~cm})$ e $18(10,4 \mathrm{~cm})$, com as espigas mais compridas, diferindo somente dos genótipos 1, 14 e 19.

Em 1999, sobressaiu pelas espigas mais compridas o genótipo $3(11,5 \mathrm{~cm})$, diferindo somente dos genótipos 1, 7, 12, 13, 14, 15, 16, 19 e 20. No ano seguinte, as linhagens 6 e 7 (10,1 e 10,3 cm respectivamente) exibiram as espigas mais compridas, não diferindo dos genótipos 2, 3, 4, 5, 9, 10 e 18, com comprimento da espiga entre 9,1 e $9,9 \mathrm{~cm}$.

Os dados referentes ao número de espiguetas por espiga do Ensaio de Linhagens Diaplóides de Trigo II, em Monte Alegre do Sul e Tatuí, em ambos os anos, encontram-se na Tabela 25.

A análise da variância desses dados, considerando-se em conjunto os quatro ensaios, exibiu efeitos significativos para genótipos, para ensaios e para a interação genótipos $\mathrm{x}$ ensaios. Apesar de a interação genótipos $\mathrm{x}$ ensaios ser significativa, a linhagem 5 exibiu grande número de espiguetas por espiga. 
Tabela 24. Comprimento médio da espiga dos genótipos avaliados no Ensaio de Linhagens Diaplóides de Trigo II, nas Estações Experimentais de Agronomia de Monte Alegre do Sul e Tatuí em 1999 e 2000.

\begin{tabular}{|c|c|c|c|c|c|c|c|}
\hline \multirow{3}{*}{ Genótipos } & \multicolumn{7}{|c|}{ Comprimento da espiga } \\
\hline & \multicolumn{3}{|c|}{ Monte Alegre do Sul } & \multicolumn{3}{|c|}{ Tatuí } & \multirow{2}{*}{$\begin{array}{l}\text { Média } \\
\text { Geral }\end{array}$} \\
\hline & 1999 & 2000 & Média & 1999 & 2000 & Média & \\
\hline & & & & $\mathrm{cm}$ & & & \\
\hline$\ldots \ldots \ldots$ & $7,9 \mathrm{f}$ & 7,7 e & $7,8 \mathrm{f}$ & $8,5 \mathrm{f}$ & $6,6 \mathrm{~g}$ & $7,6 \mathrm{c}$ & $7,7 \mathrm{e}$ \\
\hline $2 \ldots$ & 9,1 a-f & 9,7 a-d & 9,4 a-d & $10,7 \mathrm{a}-\mathrm{c}$ & $9,6 \mathrm{a}-\mathrm{d}$ & $10,1 \mathrm{ab}$ & $9,8 \mathrm{a}-\mathrm{c}$ \\
\hline $3 \ldots \ldots \ldots \ldots \ldots$ & $10,2 \mathrm{a}-\mathrm{c}$ & 9,9 a-c & $10,1 \mathrm{ab}$ & $11,5 \mathrm{a}$ & $9,2 \mathrm{a}-\mathrm{d}$ & $10,4 \mathrm{a}$ & $10,2 \mathrm{a}$ \\
\hline $4 \ldots \ldots \ldots \ldots$ & 9,6 a-e & 9,2 a-e & 9,4 a-d & $10,2 \mathrm{a}-\mathrm{d}$ & $9,6 \mathrm{a}-\mathrm{d}$ & $9,9 \mathrm{ab}$ & $9,6 \mathrm{a}-\mathrm{c}$ \\
\hline $5 \ldots \ldots \ldots \ldots \ldots$ & $10,4 \mathrm{a}$ & 9,7 a-d & $10,0 \mathrm{ab}$ & $10,8 \mathrm{a}-\mathrm{c}$ & $9,8 \mathrm{a}-\mathrm{c}$ & $10,3 \mathrm{a}$ & $10,2 \mathrm{a}$ \\
\hline $6 \ldots \ldots \ldots \ldots \ldots$ & $10,1 \mathrm{a}-\mathrm{d}$ & $9,5 \mathrm{a}-\mathrm{d}$ & $9,8 \mathrm{a}-\mathrm{c}$ & $11,0 \mathrm{a}-\mathrm{c}$ & $10,1 \mathrm{a}$ & $10,6 \mathrm{a}$ & $10,2 \mathrm{a}$ \\
\hline 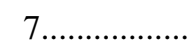 & $10,2 \mathrm{a}-\mathrm{c}$ & 9,6 a-d & $9,9 \mathrm{ab}$ & 9,9 c-e & $10,3 \mathrm{a}$ & $10,1 \mathrm{ab}$ & $10,0 \mathrm{ab}$ \\
\hline 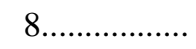 & 9,7 a-e & $9,8 \mathrm{a}-\mathrm{c}$ & $9,8 \mathrm{a}-\mathrm{c}$ & $10,8 \mathrm{a}-\mathrm{c}$ & $8,3 \mathrm{~d}-\mathrm{f}$ & $9,6 \mathrm{a}-\mathrm{c}$ & 9,7 a-c \\
\hline $9 \ldots \ldots \ldots \ldots \ldots$ & $10,5 \mathrm{a}$ & $10,4 \mathrm{a}$ & $10,5 \mathrm{a}$ & $11,3 \mathrm{ab}$ & 9,1 a-e & $10,2 \mathrm{ab}$ & $10,4 \mathrm{a}$ \\
\hline 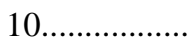 & $10,6 \mathrm{a}$ & 9,4 a-d & $10,0 \mathrm{ab}$ & $10,7 \mathrm{a}-\mathrm{c}$ & $9,9 \mathrm{ab}$ & $10,3 \mathrm{a}$ & $10,1 \mathrm{a}$ \\
\hline 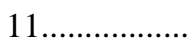 & $10,3 \mathrm{ab}$ & $10,2 \mathrm{ab}$ & $10,2 \mathrm{ab}$ & 10,9 a-c & $8,6 \mathrm{~b}-\mathrm{f}$ & $9,7 \mathrm{a}-\mathrm{c}$ & $10,0 \mathrm{ab}$ \\
\hline $12 \ldots \ldots \ldots \ldots \ldots$ & 9,5 a-e & 8,7 b-e & 9,1 b-e & $9,2 \mathrm{~d}-\mathrm{f}$ & $8,3 \mathrm{~d}-\mathrm{f}$ & $8,8 \mathrm{a}-\mathrm{c}$ & 8,9 b-d \\
\hline $13 \ldots \ldots \ldots \ldots \ldots \ldots$ & 9,8 a-e & 8,8 a-e & 9,3 b-e & $9,1 \mathrm{~d}-\mathrm{f}$ & 7,7 e-g & $8,4 \mathrm{a}-\mathrm{c}$ & $8,8 \mathrm{c}-\mathrm{e}$ \\
\hline $14 \ldots \ldots \ldots \ldots \ldots$ & $8,6 \mathrm{~d}-\mathrm{f}$ & $8,4 \mathrm{c}-\mathrm{e}$ & $8,5 \mathrm{~d}-\mathrm{f}$ & $8,4 \mathrm{f}$ & $7,6 \mathrm{fg}$ & $8,0 \mathrm{bc}$ & $8,2 \mathrm{de}$ \\
\hline $15 \ldots \ldots \ldots \ldots$ & 9,2 a-f & 9,0 a-e & 9,1 b-e & $10,0 \mathrm{~b}-\mathrm{d}$ & $7,6 \mathrm{fg}$ & $8,8 \mathrm{a}-\mathrm{c}$ & 8,9 b-d \\
\hline $16 \ldots \ldots \ldots \ldots$ & $8,7 \mathrm{c}-\mathrm{f}$ & $8,3 \mathrm{c}-\mathrm{e}$ & $8,5 \mathrm{~d}-\mathrm{f}$ & $9,0 \mathrm{~d}-\mathrm{f}$ & 7,7 e-g & $8,4 \mathrm{a}-\mathrm{c}$ & $8,4 \mathrm{de}$ \\
\hline $17 \ldots \ldots \ldots$ & $10,3 \mathrm{ab}$ & 9,2 a-e & $9,8 \mathrm{a}-\mathrm{c}$ & $10,7 \mathrm{a}-\mathrm{c}$ & $8,2 \mathrm{~d}-\mathrm{f}$ & $9,4 a-c$ & $9,6 a-c$ \\
\hline 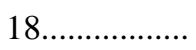 & $10,4 \mathrm{a}$ & 9,4 a-d & $9,9 \mathrm{ab}$ & $11,2 \mathrm{a}-\mathrm{c}$ & $9,6 \mathrm{a}-\mathrm{d}$ & $10,4 \mathrm{a}$ & $10,2 \mathrm{a}$ \\
\hline $19 \ldots \ldots$ & $8,3 \mathrm{ef}$ & $8,1 \mathrm{de}$ & $8,2 \mathrm{ef}$ & 8,6 ef & $7,4 \mathrm{fg}$ & $8,0 \mathrm{bc}$ & $8,1 \mathrm{de}$ \\
\hline $20 \ldots \ldots \ldots$ & $8,8 \mathrm{~b}-\mathrm{f}$ & 8,6 b-e & $8,7 \mathrm{c}-\mathrm{f}$ & $8,9 \mathrm{~d}-\mathrm{f}$ & $8,4 \mathrm{c}-\mathrm{f}$ & $8,6 \mathrm{a}-\mathrm{c}$ & $8,7 \mathrm{c}-\mathrm{e}$ \\
\hline F (Gen.) & $7,34 *$ & $5,17 *$ & $11,57^{*}$ & $16,03 *$ & $14,02^{*}$ & $5,68^{*}$ & $13,29^{*}$ \\
\hline F (Anos) & - & - & $20,26^{*}$ & - & - & $59,41 *$ & - \\
\hline F (Ensaios) & - & - & - & - & - & - & $34,50^{*}$ \\
\hline$F(G \times A)$ & - & - & 0,98 & - & - & $4,54^{*}$ & - \\
\hline$F(G \times E)$ & - & - & - & - & - & - & $2,46^{*}$ \\
\hline d.m.s. ${ }^{(1)}$ & 1,57 & 1,68 & 1,25 & 1,36 & 1,49 & 2,33 & 1,19 \\
\hline C.V. (\%) & 6,22 & 6,96 & 6,60 & 5,13 & 6,56 & 5,76 & 6,20 \\
\hline
\end{tabular}

${ }^{(1)}$ Médias seguidas de, pelo menos, uma letra comum não diferem, entre si, pelo teste de Tukey.

* Significativo a $5 \%$. 
Na média dos quatro Ensaios II, a linhagem $5(25,4)$ destacou-se pelo maior número de espiguetas por espiga, não diferindo somente da linhagem $6(23,2)$.

A linhagem $5(26,3)$ exibiu o maior número de espiguetas por espiga, só não diferindo da $6(22,7)$.

Em Tatuí, na média dos dois anos, observaram-se efeitos significativos para genótipos, para ensaios e para a interação genótipos x anos, indicando que os genótipos apresentaram comportamento diferencial em relação aos anos.

Em 1999, a linhagem $5(26,3)$ exibiu o maior número de espiguetas por espiga, não diferindo somente das linhagens 6 (23,8) e 18 (24,7). Já em 2000, a linhagem $6(23,8)$ sobressaiu com o maior número de espiguetas por espiga, diferindo dos demais genótipos, com exceção das linhagens $4(21,6)$ e $5(22,8)$.

A análise da variância para o número de grãos por espiga dos genótipos no Ensaio II (Tabela 26), em 1999 e 2000, mostrou efeitos significativos para genótipos, para ensaios e para a interação genótipos x ensaios.

$\mathrm{Na}$ média dos quatro ensaios, a linhagem $16(48,4)$, apresentou o maior número de grãos por espiga, diferindo somente das linhagens 1, 7 e 10, com o número de grãos por espiga de 34,5 a 38,1 .

Em Monte Alegre do Sul, a análise da variância para o número de grãos por espiga mostrou efeitos significativos somente para genótipos e para anos, quando avaliados em conjunto os dois anos.

Considerando-se em conjunto os ensaios instalados em Monte Alegre do Sul, o teste de médias destacou os genótipos $16(48,8), 17(48,9)$ e $20(48,9)$ pelo maior número de grãos por espiga, diferindo somente das linhagens 3, 5, 7 e 10 as quais variaram de 32,5 a 39,2 .

Em relação à característica grãos por espigueta (Tabela 27), a análise da variância mostrou efeitos significativos para genótipos, para ensaios e para a interação genótipos x ensaios, quando avaliados em conjunto os ensaios de Monte Alegre do Sul e Tatuí, nos dois anos. Na média dos quatro ensaios, destacou-se a linhagem 16 (2,71), com o maior número de grãos por espigueta, não diferindo dos genótipos 1, 2, 8, 12, 14, 15, 17 e 20, cujo número de grãos por espiga variou de 2,24 a 2,59. 
Tabela 25. Número de espiguetas por espiga dos genótipos avaliados no Ensaio de Linhagens Diaplóides de Trigo II, nas Estações Experimentais de Agronomia de Monte Alegre do Sul e Tatuí em 1999 e 2000.

\begin{tabular}{|c|c|c|c|c|c|c|c|}
\hline \multirow{3}{*}{ Genótipos } & \multicolumn{7}{|c|}{ Número de espiguetas por espiga } \\
\hline & \multicolumn{3}{|c|}{ Monte Alegre do Sul } & \multicolumn{3}{|c|}{ Tatuí } & \multirow{2}{*}{$\begin{array}{c}\text { Média } \\
\text { geral }\end{array}$} \\
\hline & 1999 & 2000 & Média & 1999 & 2000 & Média & \\
\hline & & & & $-\mathrm{n}^{\circ}$ & & & \\
\hline$\ldots$. & $17,8 \mathrm{fg}$ & $17,2 \mathrm{f}$ & 17,5 ef & $17,6 \mathrm{f}-\mathrm{h}$ & $14,7 \mathrm{i}$ & $16,1 \mathrm{ef}$ & $16,8 \mathrm{fg}$ \\
\hline$\ldots$ & $19,7 \mathrm{c}-\mathrm{g}$ & $18,9 \mathrm{c}-\mathrm{f}$ & $19,3 \mathrm{~b}-\mathrm{f}$ & 21,4 c-e & $18,7 \mathrm{c}-\mathrm{g}$ & 20,0 b-e & $19,7 \mathrm{~cd}$ \\
\hline $3 \ldots \ldots \ldots \ldots \ldots \ldots$ & 20,9 c-e & $20,1 \mathrm{~b}-\mathrm{f}$ & $20,5 b-f$ & $21,9 \mathrm{~cd}$ & $17,1 \mathrm{e}-\mathrm{i}$ & 19,5 b-f & $20,0 \mathrm{~cd}$ \\
\hline $4 \ldots \ldots \ldots \ldots$ & $22,4 \mathrm{bc}$ & $21,9 \mathrm{a}-\mathrm{c}$ & $22,1 \mathrm{bc}$ & $22,0 \mathrm{~b}-\mathrm{d}$ & 21,6 a-c & 21,8 a-d & $21,9 \mathrm{bc}$ \\
\hline ......... & $28,3 \mathrm{a}$ & $24,2 \mathrm{a}$ & $26,3 \mathrm{a}$ & $26,3 \mathrm{a}$ & $22,8 \mathrm{ab}$ & 24,6 a & $25,4 \mathrm{a}$ \\
\hline $6 \ldots \ldots \ldots \ldots \ldots$ & $22,4 \mathrm{bc}$ & $23,1 \mathrm{ab}$ & $22,7 \mathrm{ab}$ & $23,8 \mathrm{a}-\mathrm{c}$ & $23,8 \mathrm{a}$ & $23,8 \mathrm{ab}$ & $23,2 \mathrm{ab}$ \\
\hline 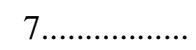 & $21,1 \mathrm{c}-\mathrm{e}$ & $19,6 \mathrm{c}-\mathrm{f}$ & $20,3 \mathrm{~b}-\mathrm{f}$ & $18,3 \mathrm{fg}$ & $19,0 \mathrm{c}-\mathrm{f}$ & $18,6 \mathrm{c}-\mathrm{f}$ & $19,5 \mathrm{c}-\mathrm{e}$ \\
\hline 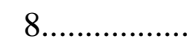 & $19,0 \mathrm{~d}-\mathrm{g}$ & $18,3 \mathrm{~d}-\mathrm{f}$ & $18,7 \mathrm{c}-\mathrm{f}$ & $18,0 \mathrm{f}-\mathrm{h}$ & $14,9 \mathrm{i}$ & 16,4 ef & $17,5 \mathrm{~d}-\mathrm{g}$ \\
\hline 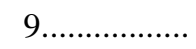 & $21,4 \mathrm{~cd}$ & $21,3 \mathrm{a}-\mathrm{d}$ & $21,3 \mathrm{~b}-\mathrm{d}$ & 19,9 d-f & $16,3 \mathrm{f}-\mathrm{i}$ & $18,1 \mathrm{~d}-\mathrm{f}$ & $19,7 \mathrm{~cd}$ \\
\hline 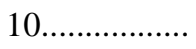 & $21,6 \mathrm{~cd}$ & $19,2 \mathrm{c}-\mathrm{f}$ & 20,4 b-f & $19,7 \mathrm{~d}-\mathrm{f}$ & $19,6 \mathrm{c}-\mathrm{e}$ & 19,6 b-e & $20,0 \mathrm{~cd}$ \\
\hline 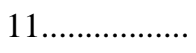 & $21,2 \mathrm{~cd}$ & $20,3 b-f$ & $20,8 b-f$ & $20,3 \mathrm{~d}-\mathrm{f}$ & $17,5 \mathrm{~d}-\mathrm{i}$ & $18,9 \mathrm{c}-\mathrm{f}$ & $19,8 \mathrm{~cd}$ \\
\hline $12 \ldots \ldots \ldots \ldots \ldots$ & $18,3 \mathrm{e}-\mathrm{g}$ & 17,7 ef & $18,0 \mathrm{~d}-\mathrm{f}$ & $16,6 \mathrm{gh}$ & $15,9 \mathrm{~g}-\mathrm{i}$ & 16,2 ef & $17,1 \mathrm{e}-\mathrm{g}$ \\
\hline $13 \ldots \ldots \ldots \ldots \ldots \ldots$ & $22,3 \mathrm{bc}$ & $19,8 \mathrm{c}-\mathrm{f}$ & $21,0 \mathrm{~b}-\mathrm{e}$ & $20,2 \mathrm{~d}-\mathrm{f}$ & 17,9 d-h & $19,0 \mathrm{c}-\mathrm{f}$ & $20,0 \mathrm{~cd}$ \\
\hline$\ldots \ldots \ldots$ & $17,0 \mathrm{~g}$ & 17,7 ef & $17,3 \mathrm{f}$ & $15,5 \mathrm{~h}$ & $15,0 \mathrm{hi}$ & $15,2 \mathrm{f}$ & $16,3 \mathrm{~g}$ \\
\hline $15 \ldots \ldots \ldots \ldots$ & $19,1 \mathrm{~d}-\mathrm{g}$ & $19,6 \mathrm{c}-\mathrm{f}$ & $19,3 \mathrm{~b}-\mathrm{f}$ & 19,4 d-f & $16,5 \mathrm{f}-\mathrm{i}$ & $17,9 \mathrm{~d}-\mathrm{f}$ & $18,6 \mathrm{~d}-\mathrm{g}$ \\
\hline $16 \ldots \ldots \ldots \ldots$ & $19,8 \mathrm{c}-\mathrm{g}$ & $19,1 \mathrm{c}-\mathrm{f}$ & 19,4 b-f & $19,3 \mathrm{~d}-\mathrm{g}$ & $17,4 \mathrm{~d}-\mathrm{i}$ & $18,3 \mathrm{c}-\mathrm{f}$ & $18,9 \mathrm{~d}-\mathrm{f}$ \\
\hline $17 \ldots \ldots \ldots$ & $20,6 \mathrm{c}-\mathrm{f}$ & $19,3 \mathrm{c}-\mathrm{f}$ & 19,9 b-f & $18,8 \mathrm{e}-\mathrm{g}$ & $17,0 \mathrm{e}-\mathrm{i}$ & $17,9 \mathrm{~d}-\mathrm{f}$ & $18,9 \mathrm{~d}-\mathrm{f}$ \\
\hline $18 \ldots \ldots . . . . . .$. & $24,5 \mathrm{~b}$ & 20,8 b-e & $22,6 \quad b$ & $24,7 \mathrm{ab}$ & 20,4 b-d & $22,5 \mathrm{a}-\mathrm{c}$ & $22,6 \mathrm{~b}$ \\
\hline $19 \ldots \ldots \ldots$ & $20,8 \mathrm{c}-\mathrm{e}$ & $20,5 \mathrm{~b}-\mathrm{e}$ & 20,6 b-f & 19,4 d-f & $17,7 \mathrm{~d}-\mathrm{i}$ & $18,5 \mathrm{c}-\mathrm{f}$ & 19,6 c-e \\
\hline $20 \ldots \ldots \ldots \ldots$ & 20,9 c-e & 19,9 b-f & 20,4 b-f & $19,9 \mathrm{~d}-\mathrm{f}$ & $18,6 \mathrm{c}-\mathrm{g}$ & $19,2 \mathrm{c}-\mathrm{f}$ & $19,8 \mathrm{~cd}$ \\
\hline F (Gen.) & $20,34 *$ & $7,54 *$ & $10,07^{*}$ & $25,21 *$ & $18,17 *$ & $10,59 *$ & $19,11^{*}$ \\
\hline F (Anos) & - & - & $13,08^{*}$ & - & - & $35,30 *$ & - \\
\hline F (Ensaios) & - & - & - & - & - & - & $28,02^{*}$ \\
\hline$F(G \times A)$ & - & - & 2,00 & - & - & $3,76^{*}$ & - \\
\hline$F(G \times E)$ & - & - & - & - & - & - & $2,83^{*}$ \\
\hline d.m.s. ${ }^{(1)}$ & 2,88 & 3,35 & 3,71 & 2,76 & 3,11 & 4,37 & 2,64 \\
\hline C.V. $(\%)$ & 5,24 & 6,42 & 6,31 & 5,23 & 6,55 & 5,80 & 6,08 \\
\hline
\end{tabular}

${ }^{(1)}$ Médias seguidas de, pelo menos, uma letra comum não diferem, entre si, pelo teste de Tukey.

* Significativo a $5 \%$. 
Tabela 26. Número de grãos por espiga dos genótipos avaliados no Ensaio de Linhagens Diaplóides de Trigo II, nas Estações Experimentais de Agronomia de Monte Alegre do Sul e Tatuí em 1999 e 2000.

\begin{tabular}{|c|c|c|c|c|c|c|c|}
\hline \multirow{3}{*}{ Genótipos } & \multicolumn{7}{|c|}{ Número de grãos por espiga } \\
\hline & \multicolumn{3}{|c|}{ Monte Alegre do Sul } & \multicolumn{3}{|c|}{ Tatuí } & \multirow{2}{*}{$\begin{array}{c}\text { Média } \\
\text { geral }\end{array}$} \\
\hline & 1999 & 2000 & Média & 1999 & 2000 & Média & \\
\hline & & & & - $\mathrm{n}^{\circ}-$ & & & \\
\hline $1 \ldots \ldots \ldots \ldots$ & $41,2 \mathrm{a}-\mathrm{d}$ & $38,1 \mathrm{ab}$ & 39,6 a-c & $45,2 \mathrm{~b}-\mathrm{e}$ & $27,8 \mathrm{bc}$ & 36,5 & $38,1 \mathrm{~b}-\mathrm{d}$ \\
\hline $2 \ldots \ldots \ldots \ldots$ & 44,3 a-c & $44,5 \mathrm{ab}$ & $44,4 \mathrm{ab}$ & $51,6 \mathrm{a}-\mathrm{d}$ & $42,5 \mathrm{a}$ & 47,0 & $45,7 \mathrm{a}-\mathrm{c}$ \\
\hline $3 \ldots \ldots \ldots \ldots \ldots$ & 42,7 a-d & $34,7 \mathrm{ab}$ & $38,7 \mathrm{bc}$ & 47,5 a-e & $35,7 \mathrm{a}-\mathrm{c}$ & 41,6 & $40,1 \mathrm{a}-\mathrm{d}$ \\
\hline $4 \ldots \ldots \ldots \ldots$ & $46,3 \mathrm{a}-\mathrm{c}$ & $38,6 \mathrm{ab}$ & $42,4 \mathrm{ab}$ & 50,0 a-d & $39,4 \mathrm{ab}$ & 44,7 & $43,6 \mathrm{a}-\mathrm{d}$ \\
\hline 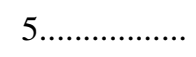 & $42,1 \mathrm{a}-\mathrm{d}$ & $36,2 \mathrm{ab}$ & $39,2 \mathrm{bc}$ & 49,5 a-e & $38,0 \mathrm{ab}$ & 43,7 & $41,4 \mathrm{a}-\mathrm{d}$ \\
\hline 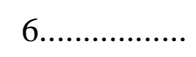 & 44,6 a-c & $41,5 \mathrm{ab}$ & $43,0 \mathrm{ab}$ & $51,3 \mathrm{a}-\mathrm{d}$ & $35,1 \mathrm{a}-\mathrm{c}$ & 43,2 & $43,1 \mathrm{a}-\mathrm{d}$ \\
\hline 7 ...................... & $31,1 \mathrm{~d}$ & $33,9 \mathrm{~b}$ & $32,5 \mathrm{c}$ & $33,6 \mathrm{f}$ & $39,6 \mathrm{ab}$ & 36,6 & $34,5 \mathrm{~d}$ \\
\hline 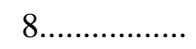 & $45,5 \mathrm{a}-\mathrm{c}$ & $43,1 \mathrm{ab}$ & $44,3 \mathrm{ab}$ & $53,0 \mathrm{a}-\mathrm{c}$ & $35,4 \mathrm{a}-\mathrm{c}$ & 44,2 & $44,2 \mathrm{a}-\mathrm{d}$ \\
\hline 9 & $44,0 \mathrm{a}-\mathrm{c}$ & $40,2 \mathrm{ab}$ & $42,1 \mathrm{ab}$ & $51,0 \mathrm{a}-\mathrm{d}$ & $30,8 \mathrm{a}-\mathrm{c}$ & 40,9 & $41,5 \mathrm{a}-\mathrm{d}$ \\
\hline $10 \ldots \ldots \ldots$ & $39,5 \mathrm{~cd}$ & $31,0 \quad b$ & $35,2 \mathrm{bc}$ & 39,2 e-f & $33,8 \mathrm{a}-\mathrm{c}$ & 36,5 & $35,9 \mathrm{c}-\mathrm{d}$ \\
\hline 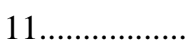 & 45,6 a-c & $39,3 \mathrm{ab}$ & $42,4 \mathrm{ab}$ & $56,6 \mathrm{a}$ & $32,3 \mathrm{a}-\mathrm{c}$ & 44,4 & $43,4 \mathrm{a}-\mathrm{d}$ \\
\hline $12 \ldots \ldots \ldots \ldots$ & 41,6 a-d & $40,6 \mathrm{ab}$ & $41,1 \mathrm{a}-\mathrm{c}$ & $41,7 \mathrm{~d}-\mathrm{f}$ & $39,7 \mathrm{ab}$ & 40,7 & 40,9 a-d \\
\hline $13 \ldots \ldots \ldots$ & 48,4 a-c & $40,7 \mathrm{ab}$ & $44,5 \mathrm{ab}$ & $41,4 \mathrm{~d}-\mathrm{f}$ & $24,1 \mathrm{c}$ & 32,8 & 38,6 a-d \\
\hline $14 \ldots \ldots \ldots \ldots$ & $44,1 \mathrm{a}-\mathrm{c}$ & $42,9 \mathrm{ab}$ & $43,5 \mathrm{ab}$ & $44,3 \mathrm{c}-\mathrm{e}$ & $37,0 \mathrm{a}-\mathrm{c}$ & 40,6 & $42,1 \mathrm{a}-\mathrm{d}$ \\
\hline $15 \ldots \ldots \ldots \ldots$ & $46,7 \mathrm{a}-\mathrm{c}$ & $41,3 \mathrm{ab}$ & $44,0 \mathrm{ab}$ & 50,3 a-d & $32,2 \mathrm{a}-\mathrm{c}$ & 41,2 & $42,6 \mathrm{a}-\mathrm{d}$ \\
\hline $16 \ldots \ldots \ldots \ldots$ & $52,6 \mathrm{ab}$ & $45,0 \mathrm{ab}$ & $48,8 \mathrm{a}$ & $58,0 \mathrm{a}$ & $38,3 \mathrm{ab}$ & 48,1 & $48,4 \mathrm{a}$ \\
\hline $17 \ldots \ldots \ldots \ldots$ & $53,1 \mathrm{a}$ & $44,8 \mathrm{ab}$ & $48,9 \mathrm{a}$ & $55,4 \mathrm{ab}$ & $38,4 \mathrm{ab}$ & 46,9 & $47,9 \mathrm{ab}$ \\
\hline $18 \ldots \ldots \ldots$ & $44,1 \mathrm{a}-\mathrm{c}$ & $36,2 \mathrm{ab}$ & $40,1 \mathrm{a}-\mathrm{c}$ & $43,2 \mathrm{c}-\mathrm{f}$ & $38,8 \mathrm{ab}$ & 41,0 & $40,6 \mathrm{a}-\mathrm{d}$ \\
\hline $19 \ldots \ldots \ldots$ & $40,5 \mathrm{~b}-\mathrm{d}$ & $38,4 \mathrm{ab}$ & 39,4 a-c & $41,0 \mathrm{~d}-\mathrm{f}$ & $33,6 \mathrm{a}-\mathrm{c}$ & 37,3 & 38,4 a-d \\
\hline $20 \ldots \ldots \ldots \ldots \ldots$ & $49,5 \mathrm{a}-\mathrm{c}$ & $48,3 \mathrm{a}$ & $48,9 \mathrm{a}$ & $51,5 \mathrm{a}-\mathrm{d}$ & $43,0 \mathrm{a}$ & 47,2 & $48,0 \mathrm{ab}$ \\
\hline F (Gen.) & $4,05^{*}$ & $2,50 *$ & $6,35^{*}$ & $9,73^{*}$ & $3,35^{*}$ & 1,30 & $3,85^{*}$ \\
\hline $\mathrm{F}$ (Anos) & - & - & $34,75^{*}$ & - & - & $52,37 *$ & - \\
\hline F (Ensaios) & - & - & - & - & - & - & $35,80^{*}$ \\
\hline$F(G \times A)$ & - & - & 0,84 & - & - & $5,06^{*}$ & - \\
\hline$F(G \times E)$ & - & - & - & - & - & - & $2,52 *$ \\
\hline d.m.s. ${ }^{(1)}$ & 12,54 & 14,10 & 9,62 & 10,71 & 13,60 & 21,28 & 10,17 \\
\hline C.V. (\%) & 10,77 & 13,45 & 12,24 & 8,55 & 14,49 & 11,14 & 11,71 \\
\hline
\end{tabular}

${ }^{(1)}$ Médias seguidas de, pelo menos, uma letra comum não diferem, entre si, pelo teste de Tukey.

* Significativo a $5 \%$. 
Efeitos significativos para genótipos, para anos e para a interação genótipos $\mathrm{X}$ anos foram obtidos na análise dos dados de Tatuí, quando avaliados em conjunto os dois anos. A comparação das médias dos genótipos mediante o teste de Tukey a 5\% não mostrou diferença entre eles.

Em 1999, na Estação Experimental de Agronomia de Tatuí, o genótipo 16 $(3,01)$ exibiu o maior número de grãos por espigueta, não diferindo dos genótipos 1,8 , 9, 11, 14, 15, 17 e 20, os quais apresentaram um número de grãos por espigueta entre 2,57 e 2,95. Em 2000, com 2,47 grãos por espigueta, destacaram-se as linhagens 12 e 14, diferindo somente das linhagens 5, 6, 10 e 13, as quais exibiram um número de grãos por espigueta igual ou inferior a 1,70 .

Na Tabela 28, encontram-se os dados referentes à massa de cem grãos dos genótipos avaliados nos ensaios das Estações Experimentais de Agronomia de Monte Alegre do Sul e de Tatuí, em 1999 e 2000.

A análise conjunta dos quatro ensaios, de Monte Alegre do Sul e Tatuí, nos dois anos, apresentou efeitos significativos para genótipos, para ensaios e para a interação genótipos x ensaios, mostrando comportamento diferencial dos genótipos em relação aos ambientes. Essa interação poderia ser explicada considerando ser a característica massa de cem grãos controlada por vários genes e apresentar baixa herdabilidade em cruzamentos (Camargo, 1987) e, portanto, altamente influenciada pelo ambiente. Apesar da interação significativa, a linhagem 8 mostrou os grãos mais pesados, independentemente do ambiente (Tabela 28).

Pela Tabela 28, verificam-se efeitos significativos somente para genótipos e para anos, quando foram analisados em conjunto os ensaios de Monte Alegre do Sul, em 1999 e 2000. Na média dos dois anos, a linhagem 8 (4,32 g) destacou-se pelos grãos mais pesados, não diferindo das linhagens 1, 7, 12, 14 e 15 e do cultivar IAC-289, com massa de cem grãos entre 3,46 e 4,05 g.

A análise conjunta dos dados obtidos em Tatuí, em ambos os anos, mostrou efeitos significativos apenas para a interação genótipos x anos. Em 1999, as linhagens 8 $(4,51 \mathrm{~g})$ e 7 (4,38 g) destacaram-se pelos grãos mais pesados, não diferindo somente das linhagens 1, 9, 10 e 12, com a massa de cem grãos entre 3,80 e 4,18 g, e dos cultivares 
Tabela 27. Número de grãos por espigueta dos genótipos avaliados no Ensaio de Linhagens Diaplóides de Trigo II, nas Estações Experimentais de Agronomia de Monte Alegre do Sul e Tatuí em 1999 e 2000.

\begin{tabular}{|c|c|c|c|c|c|c|c|}
\hline \multirow{3}{*}{ Genótipos } & \multicolumn{7}{|c|}{ Número de grãos por espigueta } \\
\hline & \multicolumn{3}{|c|}{ Monte Alegre do Sul } & \multicolumn{3}{|c|}{ Tatuí } & \multirow{2}{*}{$\begin{array}{c}\text { Média } \\
\text { geral }\end{array}$} \\
\hline & 1999 & 2000 & Média & 1999 & 2000 & Média & \\
\hline & & & & $-\mathrm{n}^{\mathrm{o}}-$ & & & \\
\hline $1 \ldots \ldots \ldots \ldots$ & $2,31 \mathrm{a}-\mathrm{d}$ & $2,21 \mathrm{ab}$ & $2,26 b-f$ & 2,57 a-e & $1,89 \mathrm{a}-\mathrm{d}$ & 2,23 & $2,24 \mathrm{a}-\mathrm{g}$ \\
\hline & 2,23 a-e & $2,35 \mathrm{ab}$ & $2,29 \mathrm{~b}-\mathrm{e}$ & $2,41 \mathrm{c}-\mathrm{g}$ & $2,26 \mathrm{a}-\mathrm{c}$ & 2,34 & $2,31 \mathrm{a}-\mathrm{f}$ \\
\hline 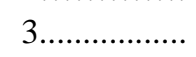 & $2,03 \mathrm{c}-\mathrm{e}$ & $1,73 \mathrm{~b}$ & $1,88 \mathrm{e}-\mathrm{i}$ & $2,17 \mathrm{e}-\mathrm{i}$ & $2,09 \mathrm{a}-\mathrm{c}$ & 2,13 & $2,01 \mathrm{~d}-\mathrm{h}$ \\
\hline $4 \ldots \ldots \ldots \ldots$ & $2,07 \mathrm{~b}-\mathrm{e}$ & $1,77 \mathrm{~b}$ & $1,92 \mathrm{~d}-\mathrm{i}$ & $2,26 \mathrm{~d}-\mathrm{h}$ & $1,83 \mathrm{a}-\mathrm{d}$ & 2,05 & $1,98 \mathrm{~d}-\mathrm{h}$ \\
\hline 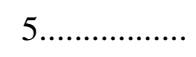 & $1,49 \mathrm{fg}$ & $1,49 \mathrm{~b}$ & $1,49 \mathrm{I}$ & $1,88 \mathrm{hi}$ & $1,66 \mathrm{~cd}$ & 1,77 & $1,63 \mathrm{~h}$ \\
\hline $6 \ldots \ldots \ldots \ldots \ldots$ & $1,99 \mathrm{c}-\mathrm{f}$ & $1,82 \mathrm{~b}$ & $1,90 \mathrm{~d}-\mathrm{i}$ & $2,17 \mathrm{e}-\mathrm{i}$ & $1,48 \mathrm{~d}$ & 1,83 & $1,86 \mathrm{f}-\mathrm{h}$ \\
\hline 7 ....................... & $1,47 \mathrm{~g}$ & $1,73 \mathrm{~b}$ & $1,60 \mathrm{hi}$ & $1,85 \mathrm{hi}$ & $2,09 \mathrm{a}-\mathrm{c}$ & 1,97 & $1,79 \mathrm{gh}$ \\
\hline 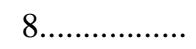 & $2,39 a-c$ & $2,36 a b$ & 2,38 a-e & $2,95 \mathrm{ab}$ & $2,38 \mathrm{ab}$ & 2,66 & $2,52 \mathrm{a}-\mathrm{c}$ \\
\hline $9 \ldots \ldots \ldots \ldots$ & $2,06 \mathrm{c}-\mathrm{e}$ & $1,87 \mathrm{~b}$ & $1,96 \mathrm{c}-\mathrm{i}$ & 2,57 a-e & 1,91 a-d & 2,24 & $2,10 \mathrm{c}-\mathrm{h}$ \\
\hline $10 \ldots \ldots \ldots$ & $1,83 \mathrm{~d}-\mathrm{g}$ & $1,62 \mathrm{~b}$ & $1,73 \mathrm{~g}-\mathrm{i}$ & $1,99 \mathrm{~g}-\mathrm{i}$ & $1,70 \mathrm{~b}-\mathrm{d}$ & 1,85 & $1,79 \mathrm{gh}$ \\
\hline 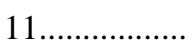 & 2,14 a-e & $1,93 \mathrm{~b}$ & $2,04 \mathrm{~b}-\mathrm{h}$ & $2,80 \mathrm{a}-\mathrm{c}$ & $1,84 \mathrm{a}-\mathrm{d}$ & 2,32 & $2,18 \mathrm{~b}-\mathrm{g}$ \\
\hline $12 \ldots \ldots \ldots \ldots$ & 2,28 a-e & $2,30 \mathrm{ab}$ & 2,29 b-e & $2,52 \mathrm{~b}-\mathrm{f}$ & $2,47 \mathrm{a}$ & 2,5 & 2,39 a-e \\
\hline $13 \ldots \ldots \ldots$ & 2,17 a-e & $2,09 \mathrm{ab}$ & $2,13 \mathrm{~b}-\mathrm{g}$ & $2,07 \mathrm{f}-\mathrm{i}$ & $1,36 \mathrm{~d}$ & 1,72 & $1,92 \mathrm{e}-\mathrm{h}$ \\
\hline $14 \ldots \ldots \ldots \ldots$ & $2,58 \mathrm{a}$ & $2,45 \mathrm{ab}$ & $2,52 \mathrm{ab}$ & $2,87 \mathrm{ab}$ & $2,47 \mathrm{a}$ & 2,67 & $2,59 \mathrm{ab}$ \\
\hline $15 \ldots \ldots \ldots \ldots$ & $2,42 \mathrm{a}-\mathrm{c}$ & $2,10 a b$ & $2,26 b-f$ & 2,59 a-e & 1,94 a-d & 2,27 & $2,26 \mathrm{a}-\mathrm{g}$ \\
\hline $16 \ldots \ldots \ldots \ldots$ & $2,63 \mathrm{a}$ & $2,99 \mathrm{a}$ & $2,81 \mathrm{a}$ & $3,01 \mathrm{a}$ & $2,20 \mathrm{a}-\mathrm{c}$ & 2,61 & $2,71 \mathrm{a}$ \\
\hline $17 \ldots \ldots \ldots \ldots . . .$. & $2,57 \mathrm{ab}$ & $2,32 \mathrm{ab}$ & $2,44 \mathrm{a}-\mathrm{c}$ & $2,95 \mathrm{ab}$ & $2,24 \mathrm{a}-\mathrm{c}$ & 2,6 & $2,52 \mathrm{a}-\mathrm{c}$ \\
\hline $18 \ldots \ldots \ldots$ & $1,79 \mathrm{e}-\mathrm{g}$ & $1,73 \mathrm{~b}$ & $1,76 \mathrm{f}-\mathrm{i}$ & $1,75 \mathrm{i}$ & $1,91 \mathrm{a}-\mathrm{d}$ & 1,83 & $1,80 \mathrm{gh}$ \\
\hline $19 \ldots \ldots \ldots$ & $1,94 \mathrm{c}-\mathrm{g}$ & $1,87 \mathrm{~b}$ & $1,91 \mathrm{~d}-\mathrm{i}$ & $2,11 \mathrm{e}-\mathrm{i}$ & $1,91 \mathrm{a}-\mathrm{d}$ & 2,01 & $1,96 \mathrm{~d}-\mathrm{h}$ \\
\hline $20 \ldots \ldots \ldots \ldots \ldots$ & $2,38 \mathrm{a}-\mathrm{c}$ & $2,41 \mathrm{ab}$ & 2,40 a-d & $2,63 \mathrm{a}-\mathrm{d}$ & $2,31 \mathrm{a}-\mathrm{c}$ & 2,47 & $2,43 \mathrm{a}-\mathrm{d}$ \\
\hline F (Gen.) & $11,68^{*}$ & $3,49 *$ & $13,96^{*}$ & $20,74^{*}$ & $5,42^{*}$ & $3,59 *$ & $10,98^{*}$ \\
\hline $\mathrm{F}($ Anos $)$ & - & - & $4,15^{*}$ & - & - & $29,82^{*}$ & - \\
\hline F (Ensaios) & - & - & - & - & - & - & $18,20 *$ \\
\hline$F(G \times A)$ & - & - & 0,67 & - & - & $4,41 *$ & - \\
\hline$F(G \times E)$ & - & - & - & - & - & - & $1,94^{*}$ \\
\hline d.m.s. ${ }^{(1)}$ & 0,51 & 1,03 & 0,52 & 0,46 & 0,70 & 0,96 & 0,49 \\
\hline C.V. (\%) & 9,03 & 19,03 & 14,80 & 7,25 & 13,37 & 10,19 & 12,60 \\
\hline
\end{tabular}

${ }^{(1)}$ Médias seguidas de, pelo menos, uma letra comum não diferem, entre si, pelo teste de Tukey.

* Significativo a $5 \%$. 
Tabela 28. Massa de cem grãos, em gramas, dos genótipos avaliados no Ensaio de Linhagens Diaplóides de Trigo II, nas Estações Experimentais de Agronomia de Monte Alegre do Sul e Tatuí em 1999 e 2000.

\begin{tabular}{|c|c|c|c|c|c|c|c|}
\hline \multirow{3}{*}{ Genótipos } & \multicolumn{7}{|c|}{ Massa de cem grãos } \\
\hline & \multicolumn{3}{|c|}{ Monte Alegre do Sul } & \multicolumn{3}{|c|}{ Tatuí } & \multirow{2}{*}{$\begin{array}{c}\text { Média } \\
\text { geral }\end{array}$} \\
\hline & 1999 & 2000 & Média & 1999 & 2000 & Média & \\
\hline $1 \ldots \ldots \ldots \ldots$ & $4,08 \mathrm{a}-\mathrm{c}$ & $4,02 \mathrm{a}$ & $4,05 \mathrm{ab}$ & $3,97 \mathrm{a}-\mathrm{c}$ & $3,75 \mathrm{~b}-\mathrm{e}$ & $3,86 a b$ & $3,95 \mathrm{ab}$ \\
\hline $2 \ldots \ldots \ldots \ldots$ & $3,09 \mathrm{~d}-\mathrm{f}$ & $2,66 \mathrm{c}-\mathrm{g}$ & $2,87 \mathrm{~d}-\mathrm{f}$ & $2,77 \mathrm{f}-\mathrm{i}$ & 3,66 b-e & $3,21 a b$ & $3,04 \mathrm{~b}-\mathrm{d}$ \\
\hline 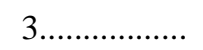 & 3,44 c-e & $2,22 \mathrm{e}-\mathrm{g}$ & $2,83 \mathrm{df}$ & $3,20 \mathrm{~d}-\mathrm{h}$ & $3,90 \mathrm{a}-\mathrm{d}$ & $3,55 a b$ & $3,19 \mathrm{~b}-\mathrm{d}$ \\
\hline $4 \ldots \ldots \ldots \ldots$ & $3,67 \mathrm{c}-\mathrm{e}$ & $2,51 \mathrm{~d}-\mathrm{g}$ & $3,09 \mathrm{c}-\mathrm{f}$ & 3,54 b-e & $3,82 \mathrm{~b}-\mathrm{d}$ & $3,68 a b$ & $3,38 \mathrm{~b}-\mathrm{d}$ \\
\hline $5 \ldots \ldots \ldots \ldots \ldots$ & $3,51 \mathrm{c}-\mathrm{e}$ & $2,53 \mathrm{~d}-\mathrm{g}$ & $3,02 \mathrm{~d}-\mathrm{f}$ & $2,60 \mathrm{~g}-\mathrm{i}$ & $3,73 \mathrm{~b}-\mathrm{e}$ & $3,17 \mathrm{ab}$ & $3,09 \mathrm{~b}-\mathrm{d}$ \\
\hline $6 \ldots \ldots \ldots \ldots . . .$. & $3,70 \mathrm{~cd}$ & $2,77 \mathrm{c}-\mathrm{g}$ & $3,23 \mathrm{~b}-\mathrm{e}$ & $3,49 \mathrm{~b}-\mathrm{f}$ & $3,86 \mathrm{~b}-\mathrm{d}$ & $3,68 a b$ & 3,46 a-c \\
\hline 7....................... & $4,41 \mathrm{ab}$ & $3,51 \mathrm{a}-\mathrm{c}$ & 3,96 a-c & $4,38 \mathrm{a}$ & $2,68 \mathrm{f}-\mathrm{h}$ & $3,53 a b$ & $3,74 a b$ \\
\hline $8 \ldots$. & $4,71 \mathrm{a}$ & $3,92 \mathrm{ab}$ & $4,32 \mathrm{a}$ & $4,51 \mathrm{a}$ & $4,76 \mathrm{a}$ & $4,63 \mathrm{a}$ & $4,48 \mathrm{a}$ \\
\hline $9 \ldots$. & $3,60 \mathrm{c}-\mathrm{e}$ & $2,91 \mathrm{c}-\mathrm{f}$ & $3,25 \mathrm{~b}-\mathrm{e}$ & $3,97 \mathrm{a}-\mathrm{c}$ & $3,07 \mathrm{~d}-\mathrm{g}$ & $3,52 \mathrm{ab}$ & 3,39 a-d \\
\hline 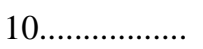 & $3,82 \mathrm{bc}$ & $2,88 \mathrm{c}-\mathrm{f}$ & $3,35 \mathrm{~b}-\mathrm{e}$ & $3,80 \mathrm{a}-\mathrm{d}$ & $2,40 \mathrm{gh}$ & $3,10 \mathrm{ab}$ & $3,22 \mathrm{~b}-\mathrm{d}$ \\
\hline $11 \ldots \ldots \ldots \ldots \ldots$ & $2,98 \mathrm{ef}$ & $2,95 \mathrm{c}-\mathrm{f}$ & $2,96 \mathrm{~d}-\mathrm{f}$ & $2,87 \mathrm{e}-\mathrm{i}$ & 3,91 a-d & $3,39 a b$ & $3,18 \mathrm{~b}-\mathrm{d}$ \\
\hline $12 \ldots \ldots \ldots \ldots$ & $3,88 \mathrm{bc}$ & $3,04 \mathrm{c}-\mathrm{e}$ & 3,46 a-d & $4,18 \mathrm{ab}$ & $3,46 b-f$ & $3,82 \mathrm{ab}$ & $3,64 \mathrm{a}-\mathrm{c}$ \\
\hline $13 \ldots \ldots \ldots \ldots$ & $3,00 \mathrm{ef}$ & $2,13 \mathrm{fg}$ & $2,57 \mathrm{ef}$ & $2,23 \mathrm{i}$ & $1,90 \mathrm{~h}$ & $2,07 \mathrm{~b}$ & $2,32 \mathrm{~d}$ \\
\hline 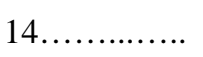 & $3,94 \mathrm{bc}$ & 3,33 a-d & $3,64 \mathrm{a}-\mathrm{d}$ & $3,63 \mathrm{~b}-\mathrm{e}$ & $4,04 \mathrm{a}-\mathrm{c}$ & $3,83 \mathrm{ab}$ & $3,74 \mathrm{ab}$ \\
\hline $15 \ldots \ldots \ldots \ldots$ & $4,01 \mathrm{bc}$ & 3,15 a-d & $3,58 \mathrm{a}-\mathrm{d}$ & $3,53 \mathrm{~b}-\mathrm{e}$ & $4,26 \mathrm{ab}$ & $3,89 a b$ & $3,74 \mathrm{ab}$ \\
\hline $16 \ldots \ldots \ldots \ldots$ & $2,68 \mathrm{f}$ & $1,92 \mathrm{~g}$ & $2,30 \mathrm{f}$ & $2,98 \mathrm{e}-\mathrm{i}$ & $2,91 \mathrm{e}-\mathrm{g}$ & $2,95 \mathrm{ab}$ & $2,62 \mathrm{~cd}$ \\
\hline $17 \ldots \ldots \ldots \ldots . .$. & 3,86 bc & $2,95 \mathrm{c}-\mathrm{f}$ & $3,41 \mathrm{~b}-\mathrm{e}$ & $3,31 \mathrm{c}-\mathrm{g}$ & $3,44 b-f$ & $3,38 a b$ & 3,39 a-d \\
\hline 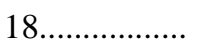 & $3,72 \mathrm{~b}-\mathrm{d}$ & 3,15 a-d & $3,43 \mathrm{~b}-\mathrm{e}$ & $2,51 \mathrm{hi}$ & $3,98 \mathrm{a}-\mathrm{c}$ & $3,25 a b$ & $3,34 \mathrm{~b}-\mathrm{d}$ \\
\hline $19 \ldots \ldots \ldots \ldots \ldots$ & $3,65 \mathrm{c}-\mathrm{e}$ & $2,92 \mathrm{c}-\mathrm{f}$ & $3,28 \mathrm{~b}-\mathrm{e}$ & 3,96 a-c & $3,35 \mathrm{c}-\mathrm{f}$ & $3,66 a b$ & 3,47 a-c \\
\hline $20 \ldots \ldots \ldots . . . .$. & $3,87 \mathrm{bc}$ & 3,35 a-d & 3,61 a-d & 3,89 a-d & $3,56 b-f$ & $3,72 a b$ & $3,67 \mathrm{a}-\mathrm{c}$ \\
\hline F (Gen.) & $13,32 *$ & $10,75^{*}$ & $10,08^{*}$ & $19,91 *$ & $15,11^{*}$ & 1,40 & $4,91^{*}$ \\
\hline F (Anos) & - & - & $114,36^{*}$ & - & - & 0,09 & - \\
\hline F (Ensaios) & - & - & - & - & - & - & $11,74 *$ \\
\hline$F(G \times A)$ & - & - & 2,06 & - & - & $14,43^{*}$ & - \\
\hline$F(G \times E)$ & - & - & - & - & - & - & $7,30 *$ \\
\hline d.m.s. ${ }^{(1)}$ & 0,70 & 0,87 & 0,89 & 0,76 & 0,90 & 2,43 & 1,09 \\
\hline C.V. (\%) & 7,22 & 11,23 & 9,19 & 8,32 & 9,70 & 8,99 & 9,09 \\
\hline
\end{tabular}

${ }^{(1)}$ Médias seguidas de, pelo menos, uma letra comum não diferem, entre si, pelo teste de Tukey.

* Significativo a $5 \%$. 
IAC-24 (3,96 g) e IAC-289 (3,89 g). Em 2000, a linhagem 8 (4,76 g) exibiu a maior massa de cem grãos, não diferindo das linhagem 3,11, 14, 15 e 18. A 8 apresentou os grãos mais pesados e a 13 (2,07 g), os mais leves nos dois anos, apesar da interação significativa, considerando-se em conjunto os ensaios em Tatuí em 1999 e 2000.

As médias dos comprimentos das raízes dos genótipos, após 72 horas de crescimento em solução normal, que se seguiu a um crescimento em solução-tratamento contendo seis diferentes concentrações de alumínio, obtidas de cinco repetições para cada solução, encontram-se na Tabela 29.

Quando avaliados em solução nutritiva com ausência de alumínio, todos os genótipos apresentaram crescimento normal das raízes, a diferença verificada entre o comprimento das raízes é de origem genética.

$\mathrm{Na}$ solução contendo 2 e $4 \mathrm{mg} \mathrm{L}^{-1}$, todos os genótipos apresentaram crescimento das raízes, sendo, portanto, considerados tolerantes a essa concentração, exceto o cultivar controle Anahuac (suscetível), sem crescimento de raízes. Os genótipos 13 e 20 apresentaram paralisação irreversível do crescimento das raízes após 72 horas de crescimento em solução normal, que se seguiu a um tratamento de 48 horas em solução com concentração de 6 e $8 \mathrm{mg} \mathrm{L}^{-1}$ de alumínio, sendo, portanto, considerados sensíveis a essa concentração, os demais genótipos, por apresentarem crescimento de raiz, foram tolerantes a essa concentração.

$\mathrm{Na}$ concentração contendo $10 \mathrm{mg} \mathrm{L}^{-1}$ de alumínio, o genótipo 10 revelou paralisação do crescimento das raízes. Esse genótipo mais as linhagens 13 e 20 foram considerados sensíveis a essa concentração, os demais, tolerantes.

Os quatro ensaios foram instalados em solo ácido com aplicação de calcário e sob irrigação por aspersão, mantendo as raízes dos genótipos, em quase sua totalidade, na camada arável. Isso não permitiu que a possível presença de alumínio no subsolo apresentasse a toxicidade aos genótipos avaliados.

Os resultados obtidos em solução nutritiva sugerem que todos os genótipos, exceto 10,13 e 20, poderiam ser semeados em condição de sequeiro e solo muito ácido com alto teor de alumínio visando a uma produção econômica 
Tabela 29. Comprimento médio das raízes dos genótipos avaliados no Ensaio de Linhagens Diaplóides de Trigo II, após 72 horas de crescimento em solução normal, que se seguiu a um crescimento em solução tratamento contendo seis concentrações de alumínio (média de cinco repetições).

\begin{tabular}{|c|c|c|c|c|c|c|}
\hline \multirow{2}{*}{ Genótipos } & \multicolumn{6}{|c|}{ Concentração de alumínio $\left(\mathrm{mg} \mathrm{L}^{-1}\right)$} \\
\hline & 0 & 2 & 4 & 6 & 8 & 10 \\
\hline & & & - & & & - \\
\hline $1 \ldots \ldots \ldots$ & 58,8 & 28,0 & 10,9 & 0,8 & 0,2 & 0,2 \\
\hline $2 \ldots \ldots \ldots$ & 62,3 & 40,4 & 11,9 & 5,5 & 2,5 & 0,1 \\
\hline $3 \ldots \ldots \ldots \ldots \ldots$ & 56,7 & 49,4 & 30,0 & 22,2 & 10,9 & 4,1 \\
\hline $4 \ldots \ldots \ldots \ldots$ & 60,0 & 48,4 & 30,9 & 23,3 & 8,9 & 0,7 \\
\hline 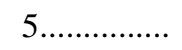 & 61,0 & 40,8 & 34,9 & 10,3 & 4,3 & 0,5 \\
\hline $6 \ldots \ldots \ldots \ldots \ldots$ & 51,5 & 40,3 & 31,2 & 20,1 & 14,0 & 9,8 \\
\hline $7 \ldots \ldots \ldots \ldots \ldots$ & 52,2 & 46,6 & 27,8 & 6,3 & 1,4 & 1,0 \\
\hline $8 \ldots \ldots \ldots \ldots . . . .$. & 61,8 & 46,1 & 41,1 & 36,2 & 20,9 & 14,2 \\
\hline $9 \ldots \ldots \ldots \ldots \ldots$ & 56,7 & 41,8 & 28,6 & 10,8 & 5,6 & 0,9 \\
\hline $10 \ldots \ldots \ldots \ldots$ & 49,4 & 31,7 & 15,3 & 5,4 & 1,1 & 0,0 \\
\hline $11 \ldots \ldots \ldots \ldots . . .$. & 53,3 & 46,8 & 37,9 & 31,3 & 20,9 & 12,3 \\
\hline $12 \ldots \ldots \ldots \ldots \ldots$ & 56,4 & 48,2 & 38,5 & 30,6 & 21,4 & 16,7 \\
\hline $13 \ldots \ldots \ldots$ & 51,5 & 3,5 & 0,7 & 0,0 & 0,0 & 0,0 \\
\hline $14 \ldots \ldots \ldots \ldots$ & 60,7 & 49,2 & 34,9 & 24,3 & 18,0 & 13,8 \\
\hline $15 \ldots \ldots \ldots \ldots$ & 61,1 & 41,7 & 22,6 & 12,3 & 3,9 & 3,2 \\
\hline $16 \ldots \ldots \ldots \ldots$ & 55,8 & 41,6 & 31,0 & 23,1 & 12,7 & 6,4 \\
\hline $17 \ldots \ldots \ldots \ldots$ & 55,7 & 40,1 & 31,3 & 20,1 & 12,1 & 10,1 \\
\hline $18 \ldots \ldots \ldots \ldots . .$. & 59,2 & 55,9 & 47,4 & 39,6 & 22,7 & 18,7 \\
\hline $19 \ldots \ldots \ldots \ldots$ & 56,8 & 48,6 & 44,5 & 31,4 & 15,4 & 10,8 \\
\hline $20 \ldots \ldots \ldots$ & 62,1 & 30,7 & 4,7 & 0,0 & 0,0 & 0,0 \\
\hline BH-1146... & 90,2 & 74,7 & 57,8 & 45,9 & 24,8 & 19,7 \\
\hline Anahuac... & 62,9 & 0,0 & 0,0 & 0,0 & 0,0 & 0,0 \\
\hline
\end{tabular}




\section{CONCLUSÕES}

1. A cultura de anteras mostrou-se uma técnica eficiente em um programa de melhoramento genético vegetal, reduzindo o tempo necessário para a obtenção de linhagens e de genótipos portadores de características agronômicas desejáveis em programas de melhoramento de trigo.

2. As linhagens diaplóides consideradas mostraram grande variabilidade para os caracteres agronômicos avaliados.

3. No Ensaio I, destacaram-se, pela produção de grãos, as linhagens 4, 5, 9, 11 e 12, diferindo, porém, apenas da 13.

4. No Ensaio I, a linhagem 13 teve as plantas mais baixas, independentemente do local em que foi avaliada, e as linhagens 2, 4 e 18 exibiram, ao mesmo tempo, moderada resistência aos agentes causais da ferrugem-da-folha e da mancha-dafolha. Essas linhagens constituem fontes genéticas para tais características. A linhagem 5 destacou-se por associar o maior número de grãos por espigueta aos grãos mais pesados.

5. O cultivar IAC-289 revelou-se sensível a $6 \mathrm{mg} \mathrm{L}^{-1}$ de alumínio, porém foi um dos mais produtivos quando avaliado em solo ácido e em condição de sequeiro em Capão Bonito, mostrando que a tolerância à toxicidade de $4 \mathrm{mg} \mathrm{L}^{-1}$, em solução nutritiva, seria suficiente para garantir-lhe um bom desenvolvimento de raízes. Todos os genótipos do Ensaio I, com exceção do cultivar IAC-289 e da linhagem 13 , mostraram-se tolerantes a $10 \mathrm{mg} \mathrm{L}^{-1}$ de $\mathrm{Al}^{3+}$.

6. No Ensaio II, destacaram-se, quanto à produção de grãos, a linhagem 8 e o cultivar IAC-289, diferindo, porém, apenas das linhagens 3, 13, 16 e 18. 
7. No Ensaio II, a linhagem 13 apresentou o porte mais baixo em todos os ensaios e a 3, resistência ao agente causal da ferrugem-da-folha, moderada resistência ao agente da mancha-da-folha e imunidade ao do oídio. Tais linhagens poderiam servir como fontes genéticas dessas características em programas de melhoramento. As linhagens 5 e 6 destacaram-se por associar as espigas mais compridas com o maior número de espiguetas por espiga.

8. Todos os genótipos do Ensaio II mostraram-se tolerantes a $10 \mathrm{mg} \mathrm{L}^{-1}$ de $\mathrm{Al}^{3+}$, quando avaliados em solução nutritiva, exceto as linhagens 10 e 13 e o cultivar IAC-289, podendo, portanto, ser utilizados em programas de melhoramento visando à obtenção de cultivares para solos ácidos. 


\section{REFERÊNCIAS BIBLIOGRÁFICAS}

ALLARD, R. W. Princípios do melhoramento genético das plantas. Trad. de A. Blumenschein, E. Paterniani, J. T. do A. Gurgel e R. Vencovsky. Rio de Janeiro: USAID, 1971. 381p.

ALVES, V. M. C.; NOVAIS, R. F.; NEVES, J. C. L.; BARROS, N. F. Efeito do alumínio sobre a absorção e translocação de fósforo e sobre a composição mineral de duas cultivares de trigo. Pesquisa Agropecuária Brasileira, v. 23, n.6, p.563-573, 1988.

BARCELLOS, A. L. As ferrugens do trigo no Brasil. In: FUNDAÇÃO CARGILL. Trigo no Brasil. Campinas, 1982. v. 2, cap. 10, p. 375-419, 1982.

BARCELLOS, A. L.; IGNACZAK, J. C. Efeito da ferrugem da folha em diferentes estádios de desenvolvimento do trigo. In: REUNIÃO ANUAL CONJUNTA DE PESQUISA DE TRIGO, 10., Porto Alegre, 1978. Solos e técnicas culturais, economia e sanidade. Passo Fundo: EMBRAPA, 1978. p. 212-219.

BARROS, B. C. Trigo-Brasil: O papel das doenças na baixa produtividade. Correio Agrícola, n. 2, p. 703-710, 1985.

BAYMA, C. Trigo. Rio de Janeiro: Serviço de Informação Agrícola, 1960. v. 1, 361p. (Estudos Técnicos, 14)

BOROJEVIC, S. Characteristics of some new dwarf and semi dwarf wheat lines. Euphytica, v. 17, n. 1, p. 143-151, 1968.

BRAUNER, J. L.; SARRUGE, J. R. Tolerância de cultivares de trigo (Triticum aestivum L.) ao alumínio e ao manganês. I. Determinação da tolerância ao alumínio. Anais da Escola Superior de Agricultura "Luiz de Queiroz", v. 37, n. 2, p. 805-824, 1980.

BRIGGS, F. N.; KNOWLES, P. F. Introduction to plant breeding. New York: Reinhold, 1967. 426 p. 
BROES, L. H. M.; WALLENBURG, S. C. Influence of post infection temperature on three components of partial resistance in wheat to wheat leaf rust. Euphytica, v. 44, n. 3, p. 215-224, 1989.

BURLEIGH, J. R.; ROELFS, A. P.; EVERSMEYER, M. G. Estimating damage to wheat caused by Puccinia recondita f. sp. tritici. Phytopathology, v. 62, n. 9, p. 944-946, 1972.

CAMARGO, C. E. O. Melhoramento do trigo: I. Herdabilidade da tolerância à toxicidade do alumínio. Bragantia, v. 40, n. 4, p. 33-45, 1981.

CAMARGO, C. E. O. Melhoramento de trigo: VI. Herdabilidade da tolerância a três concentrações de alumínio em solução nutritiva. Bragantia, v. 43, n. 2, p. 279-291, 1984.

CAMARGO, C. E. O. Melhoramento do trigo: XIII. Estimativas de variância, herdabilidade e correlações em cruzamentos de trio para a produção de grãos e tolerância à toxicidade de alumínio. Bragantia, v. 46, n. 1, p. 73-89, 1987.

CAMARGO, C. E. O.; OLIVEIRA, O. F. de. Tolerância de cultivares de trigo a diferentes níveis de alumínio em solução nutritiva e no solo. Bragantia, v. 40, n. 1, p. 21-31, 1981.

CAMARGO, C. E. O.; OLIVEIRA, O. F. Melhoramento do trigo: V. Estimativa da herdabilidade e correlações entre altura de planta, produção de grãos e outros caracteres agronômicos em trigo. Bragantia, v. 42, p. 131-148, 1983.

CAMARGO, C. E. O.; RAMOS, V. J. Herdabilidade e associação entre número de grãos por espigueta altura das plantas e produção de grãos em populações híbridas de trigo envolvendo diferentes fontes de nanismo. Pesquisa Agropecuária Brasileira, v. 24, n. 12, p 1513-1521, 1989.

CAMARGO, C. E. O.; FERREIRA FILHO, A. W. P; FELÍCIO, J. C. Herdabilidade e correlações entre características agronômicas em populações híbridas de trigo. Bragantia, v. 57, n. 1, p. 95-104, 1998.

CAMARGO, C. E. O.; ROCHA JÚNIOR, L. S.; FERREIRA FILHO, A. W. P. Melhoramento do trigo: XXVI. Avaliação de linhagens com tolerância à toxicidade de alumínio, manganês e ferro em solução nutritiva. Bragantia, v. 50, n. 2, p. 247-260, 1991c. 
CAMARGO, M. B. P.; ARRUDA, H. V.; PEDRO JÚNIOR, M. J.; BRUNINI, O.; ALFONSI, R. R. Melhores épocas de plantio do trigo no Estado de São Paulo baseadas na probabilidade de atendimento hídrico. Bragantia, v. 44, n. 1, p. 255-261, 1985.

CAMARGO, C. E. O.; FELÍCIO, J. C.; FERREIRA FILHO, A. W. P.; FREITAS, J. G. de; SANTOS, R. R.; SABINO, J. C. Melhoramento do trigo: XXII. Comportamento de linhagens originarias de trigos de inverno e de primavera no Estado de São Paulo. Bragantia, v. 48, n. 2. p. 173-203, 1989.

CAMARGO, C. E. O.; FELÍCIO, J. C.; FERREIRA FILHO, A. W. P.; FREITAS, J. G.; KANTHACK, R. A. D.; BARROS, B. C. Melhoramento de trigo: XXIV. Avaliação de novos genótipos no Estado de São Paulo. Bragantia, v. 50, n. 2, p. 203-223, $1991 b$.

CAMARGO, C. E. O.; FELÍCIO, J. C.; FERREIRA FILHO, A. W. P.; FREITAS, J. G.; BARROS, B. C.; PETTINELLI JÚNIOR, A.; SANTOS, R. R. Melhoramento de trigo: Avaliação de linhagens em diferentes regiões paulistas. Arquivos do Instituto Biológico, v. 61, n 1/2, p. 45-56, 1994.

CAMARGO, C. E. O. ; FELÍCIO, J. C.; FERREIRA FILHO, A. W. P.; FREITAS, J. G. de; BARros, B. C.; CASTRO, J. L. de; PETTINELli JÚNIOR, A.; ROCHA JÚNIOR, L. S. Melhoramento do trigo. XIX. Avaliação de novas linhagens em diferentes regiões paulistas. Bragantia, v. 47, n. 2. p. 195-211, 1988.

CAMARGO, C. E. O.; FELÍCIO, J. C.; FERREIRA FILHO, A. W. P.; FREITAS, J. G.; BARROS, B. C.; CASTRO, J. L.; SABINO, J. C.; KANTHACK, R .A. D. II. GENÉTICA E MELHORAMENTO DE PLANTAS. Melhoramento do trigo: XXIII. Avaliação de linhagens na região do Vale do Paranapanema, em Capão Bonito e em Tietê, em 1984-88. Bragantia, v. 49, n. 1, p. 43-67, 1990.

CAMARGO, C. E. O.; FELÍCIO, J. C.; FERREIRA FILHO, A. W. P.; BARROS, B. C.; FREITAS, J. G. de; PETTINELLI JÚNIOR, A.; GALLO, P. B.; KANTHACK, R. A. D. Melhoramento do trigo: XXV. Avaliação de genótipos oriundos de populações híbridas introduzidas de Oregon (EUA) no Estado de São Paulo. Bragantia, v. 50, n. 2. p. 225-246, 1991a. 
CAMARGO, C. E. O; RAMOS, L. C. S.; FERREIRA FILHO, A. W. P.; FELÍCIO, J. C.; PETTINELli JUNIOR, A.; CASTRO, J. L. de; YOKOO, E. Y. Linhagens diaplóides de trigo: produção de grãos, características agronômicas e tolerância à toxicidade de alumínio. Bragantia, v. 58, n. 2, p. 235-246, 1999.

CAMPOS, L. A. C.; FONSECA JÚNIOR, N. S.; RIEDE, C. R. Avaliação dos efeitos de geada em genótipos de trigo (Triticum aestivum). (compact disc). In: CONGRESSO BRASILEIRO DE MELHORAMENTO DE PLANTAS; 1., Goiânia, 2001. Resumos. Goiânia: EMBRAPA, 2001.

CARDOSO, E. J. B. N.; KIMATI, H. Doenças do trigo - Triticum spp. In: GALLI, F. Manual de fitopatologia. 2 ed. São Paulo: Agronômica Ceres, 1980. v. 2, cap. 36, p. 553-573.

COMPANHIA NACIONAL DE ABASTECIMENTO. Indicadores Agropecuários v. 10, n. 2, 2001. 45p.

CUNHA, G. R. da Riscos climáticos e cultivo de trigo no Brasil In: REUNIÃO NACIONAL DE PESQUISA DE TRIGO, 18. Passo Fundo, 1999. Resumos. Passo Fundo: EMBRAPA, CNPT, 1999. v. 1, p. 85-103.

FEDERIZZI, L. C.; CARVALHO, F. I. F. de.; NODARI, R. O. Análise genética do caráter período de espigamento em trigo. Pesquisa Agropecuária Brasileira, v. 17, n. 9, p. 1271-1277, 1982.

FElíCiO, J. C.; CAMARGo, C. E. O.; CAMARGO, M. B. P.; CASTRO, J. L.; BARROS, B. B. C. Trigo: três épocas de semeadura em Capão Bonito, SP, no período 1981-1985. Bragantia, v. 47, n. 2, p. 255-275, 1988.

FORCELINI, C. A.; REIS, E. M. Controle de Helminthosporum sativum, Septoria nodorum, Fusarium graminearum e Erysiphe graminis f. sp. tritici pelo tratamento de sementes de trigo com fungicidas. Fitopatologia Brasileira, v. 13, n. 1, p. 28-31, 1988.

GANDIN, C. L. Análises dos efeitos de populações segregantes e da capacidade combinatória de diferentes genótipos sobre os principais caracteres de importância agronômica em trigo. Porto Alegre, 1982. 135p. Dissertação (Mestrado) - Faculdade de Agronomia, Universidade Federal do Rio Grande do Sul. 
GE, Y.; JOHNSON, J. W.; ROBERTS, J. J.; RAJARAM, S. Temperature and resistance gene interactions in the expression of resistance to Blumeria graminis $\mathrm{f}$. sp. tritici. Euphytica, v. 99, p. 103-109, 1998.

GOUlART, A. C. P.; PAIVA, F. A. Controle de ferrugens do trigo com fungicidas triaóis em dose normal e em metade da dose isoladas ou em mistura ao mancozeb. Fitopatologia Brasileira, v. 17, n. 1, p. 80-83, 1992.

GOUlART, A. C. P.; PAIVA, F. A. de; ANDRADE, P. J. M. Efeito da aplicação de fungicidas na parte aérea do trigo e a incidência de Bipolaris sorokiniana e Pyricularia grisea em sementes. Fitopatologia Brasileira, v. 20, n. 4. p. 628-632, 1995.

INSTITUTO AGRONÔMICO DE CAMPINAS. Recomendações da Comissão Técnica de Trigo para 1999. 2. ed. Campinas, 1999. 100p. (IAC. Boletim Técnico, 167).

INSTITUTO AGRONÔMICO DE CAMPINAS. Reunião da Comissão Técnica de Trigo da Secretaria de Agricultura e Abastecimento do Estado de São Paulo: Variedades de trigo para o Estado de São Paulo. Campinas, 1996. 20 p. (IAC. Boletim Técnico, 163)

JACOBSEN, L. A. Riscos de mercado: fontes de informação e análises para tomada de decisão. In: REUNIÃO NACIONAL DE PESQUISA DE TRIGO, 18., Passo Fundo, 1999. Resumos. Passo Fundo: EMBRAPA, CNPT, 1999. v. 1, p. 104-128. JOHNSON, V. A.; BIEVER, K. J.; HAUNOLD, A.; SCHIDT, J. W. Inheritance of plant height, yield of grain, and other plant and seed characteristics in a cross of hard red winter wheat (Triticum aestivum L.). Crop Science, v. 6, p. 336-368, 1966.

LAUDE, H. H.; PAULI, A. W. Influence of lodging on yield and other characters in winter wheat. Agronomy Journal, v. 48, n. 18, p. 452-455, 1956.

LINHARES, W. I. Oídio do trigo. In: FUNDAÇÃO CARGILL. Trigo no Brasil. Campinas, 1982. v. 2, p. 423-471.

LINHARES, W. I. Fontes de resistência ao oídio do trigo; avaliação de comportamento de cultivares abrangendo os anos de 1975 a 1986. Fitopatologia Brasileira, v. 13, n. 4, p. 335-340, 1988a. 
LINHARES, W. I. Perdas de produtividade ocasionadas por oídio na cultura de trigo. Fitopatologia Brasileira, v.13, n. 1, p. 74-75, 1988b.

LINHARES, W. I.; IGNACZAK, J. C. Determinação de perdas e danos causados pelo oídio: 1976-1977. In: REUNIÃO ANUAL CONJUNTA DE PESQUISA DO TRIGO 10., Porto Alegre, RS, 1978. Solos e técnicas culturais, economia e sanidade. Passo Fundo: EMBRAPA, CNPT, 1978. p. 238-252.

LINHARES, W. I.; IGNACZAK, J. C.; PICININI, E. C. O oídio do trigo, potencial de danos e inter-relações. Pesquisa Agropecuária Brasileira, v. 23, n. 9, p. 987-996, 1988.

LINVINGSTON, J. E.; SWINBANK, J. C. Some factors influencing the injury to winter heads by low temperatures. Agronomy Journal, v. 1, p. 153-157, 1949

LYNCH, D. V. Chilling injury in plants: The relevance of membrane lipids. In: KATTERMAN, F. (Ed.) Environmental injury to plants. London: Academic Press, 1990. cap. 2, p. 17-34.

MEDEIROS, M. C.; SCHLEHUBER, A. M. Produção de grãos e componentes de produção de certas variedades brasileiras de trigo. Pesquisa Agropecuária Brasileira, v. 6, p. 45-52, 1971.

MEHTA, Y. R. Doenças do trigo e seu controle. São Paulo: Agronômica Ceres, 1978. 190p. (Ceres, 20)

MEHTA, Y. R.; IGARASHI, S. Partial resistance in wheat against Puccinia recondita, a new view on its detection in measuring. Summa Phytopathologica, v. 5, n. 1/2, p. 90-100, 1979.

MORAES-FERNANDES, M.I.B. Perspectivas da biotecnologia para o melhoramento de plantas. Pesquisa Agropecuária Brasileira, v. 22, n. 9/10, p. 881-896, 1987.

MOTA, F. S. Clima e zoneamento para a triticultura no Brasil. In: FUNDAÇÃO CARGILl. Trigo no Brasil. Campinas, 1982. v. 2, p. 29-64.

OLMOS, J. I. L.; CAMARGO, M. N. Ocorrência de alumínio tóxico nos solos do Brasil, sua caracterização e distribuição. Ciência e Cultura, v. 28, n. 2, p. 171-180, 1976.

PETERSON, R. F. Wheat, botany, cultivation and utilization. London: Leonard Hill Book, 1965. 422p. (World Crops Books) 
PICININI, E. C.; PRESTES, A. M. Trigo: fungos, prejuízo certo na lavoura. A Granja, n. 450, p. 54-56, 1985.

PIRES, D. R. V. Técnicas de melhoramento de plantas. Lisboa: Livraria Sá da Costa, 1953. 424p. (A Terra e o Homem).

POEHLMAN, J. M. Breeding field crops. New York: Holt Rinehart and Winston, 1959. $427 \mathrm{p}$.

POWELL, J. B.; SCHLEHUBER, A. M. Components of height inheritance of the semidwarf straw character in wheat (Triticum aestivum L.). Crop Science, v. 7, n. 5, p. 511-516, 1967.

RAIJ, B. van.; SILVA, N. M.; BATAGLIA, O. C.; QUAGGIO, J. A.; HIROCE, R.; CANTARELLA, H.; BELINAZZI JUNIOR, R.; DECHEN, A. R.; TRANI, P. E. Recomendações de adubação e calagem para o Estado de São Paulo. Campinas: Instituto Agronômico, 1985. 107p. (IAC. Boletim Técnico, 100)

RAMALHO, M.; SANTOS, J.B.; PINTO, C.B. Genética na agropecuária. 4. ed., São Paulo: Globo, 1995. 357p.

RAMOS, L. C. S.; YOKOO, Y.; CAMARGO, C. E. O. Cultura de anteras de trigo. I. Adequação de meios de cultura e testes de genótipos. Bragantia. v. 53, n. 2, p. 151-157, 1994.

RAMOS, L. C. S.; CAMARGO, C. E. O.; FERREIRA FILHO, A. W. P.; YOKOO, E. Y.; CASTRO, J. L.; PETTINELli JUNIOR, A.; SILVA, M. R. da. Melhoramento do trigo: avaliação de linhagens diaplóides obtidas via cultura de anteras. Scientia Agricola, v. 57, n. 1, p. 177-183, 2000.

RAWSON, H. M.; EVANS, L. T. The contribuition of stem reerves to grain development in a range of wheat cultivars of different height. Australian Journal of Agricultural Research, v. 22, p. 851-868, 1971.

REIS, E. M.; MOREIRA, J. C. S.; PRESTES, A. M. Multiplicação de Septorio nodorum, S. tritici e Helminthosporium sativum em folhas senescentes de dez cultivares de trigo em três épocas de semeadura, sob condições naturais, em 1984. Fitopatologia Brasileira, v. 12, n. 3, p. 198-202, 1987.

ROBINS, J. S.; DOMINGO, C. E. Moisture and nitrogen effects on irrigated spring wheat. Agronomy Journal, v. 54, n. 2, p. 135-138, 1962. 
ROSA, O. S.; CAMARGO, C. E. O.; RAJARAM, S.; ZANATA, A. C. A. Produtividade de trigo (Triticum aestivum (L.) Thell) com tolerância ao alumínio tóxico no solo. Pesquisa Agropecuária Brasileira, v. 29, n. 3, p. 411-417, 1994.

RUEDELL, J. Fatores que limitam o potencial produtivo do trigo no Rio Grande do Sul. In: REUNIÃO NACIONAL DE PESQUISA DE TRIGO, 18., Passo Fundo, 1999. Resumos. Passo Fundo: EMBRAPA, CNPT, 1999. v. 1, p. 36-43.

SACCO, J.C. Identificação das principais variedades de trigo no sul do Brasil. Pelotas: Instituto Agronômico do Sul, 1960. (Boletim Técnico, 26)

SCHEEREN, P. L. Danos de geada em trigo avaliação preliminar de cultivares. Pesquisa Agropecuária Brasileira, v.17, n. 6, p. 853-858, 1982.

SCHEEREN, P. L.; CARVALHO, F. I. F.; FEDERIZZI, L. C. Componentes da estatura de planta em trigo. Pesquisa Agropecuária Brasileira, v. 16, n. 4, p. 527-538, 1981.

SCHRAMM, W.; FULCO, W. S.; SOARES, M. H. G.; ALMEIDA, A. M. P. Resistência de cultivares de trigo em experimentação ou cultivo no Rio Grande do Sul, às principais doenças fúngicas. Agronomia Sulriograndense, v. 10, n. 1, p. $31-52,1974$.

SENTELHAS, P. C.; PEDRO JÚNIOR; M. J.; FELÍCIO, J. C.; IGUE, T. Estimativa agrometeorológica da ocorrência de helmintosporiose e oídio em trigo. Summa Phytopathologica, v. 19, n. 3/4, p. 180-183, 1993.

SOUZA, C. N. A. de. O acamamento e a reação de cultivares de trigo recomendados no Rio Grande do Sul. Pesquisa Agropecuária Brasileira, v. 33, p. 537-541, 1998. Número especial.

STELMARKH, A. F. Genetic systems regulating flowering response in wheat. Euphytica, v. 100, p. 359-369, 1998.

TAVELlA, C. M.; SOUSA, P. G.; LAZZAROTTO, C. Rendimento de grãos de cultivares e linhagens de trigo e algumas características anatômicas e fisiológicas. Pesquisa Agropecuária Brasileira, v. 22, n. 1, p. 59-61, 1987.

TOMASINI, R. G. A. Evolução histórica e aspectos econômicos. In: FUNDAÇÃO CARGILl. Trigo no Brasil. Campinas, 1982. v. 1, cap. 1, p. 3-25, 1982. 
TUlmANn NETO, A.; CAMARGO, C. E. de O.; CASTRO, J. L. de.; FERREIRA FILHO, A. W. P. New wheat genotypes tolerants to aluminum toxicity obtained by mutation induction. Pesquisa Agropecuária Brasileira, v. 36, n. 1, p. 61-70, 2001.

VECHIATO, M. H.; LASCA, C. C.; VALARINI, P. J. Sobrevivência do fungo Helminthosporium sativum em sementes de trigo (Triticum aestivum) armazenadas. Fitopatologia Brasileira, v. 12, n. 3, p. 226-231, 1987.

VOGEL, O. A.; CRADDOCK, J. C.; MUIR, J. R.; EVERSON, C. E.; ROHDE, E. H. Semi dwarf growth habits in winter wheat improvement for the Pacific Northwest. Agronomy Journal, v. 48, p. 76-78, 1956.

VOLKE, V. H.; INOSTRUZA, O. U. Efectos del nitrógeno y del fósforo sobre los componentes de inverno, variedad capello desprez. Agricultura Técnica, v. 23, n. 3, p. 99-105, 1967.

WAHHABE, A.; HUSSAIN, I. Effect of nitrogen on growth, quality and yield of irrigated wheat in west Parkistan. Agronomy Journal, v. 49, n. 3, p. 116-119, 1957.

WEIBEL, R. O.; PENDLETON, J. W. Effect of artificial lodging on winter wheat grain yield and quality. Agronomy Journal, v. 56, n. 5, p. 487-488, 1964.

WEISE, M. V. Compendium of wheat diseases. Saint Paul: The American Phytopathological Society, 1977. 106p.

WORLAND, A. J.; BÖRNER, A.; KORZUN, V.; LI, W. M.; PETROVIC, S.; SAYER, E. J. The influence of photoperiod genes on the adaptability of european winter wheats. Euphytica, v. 100, p. 385-394, 1998.

ZANATTA, A. C. A.; MUNDSTOCK, C. M. Efeito de níveis de fósforo e alumínio sobre os sistemas aéreo e radicular do trigo. Pesquisa Agropecuária Brasileira, v. 23, n. 12. p. 1355-1370, 1988. 